UNIVERSIDADE ESTADUAL PAULISTA

FACULDADE DE MEDICINA VETERINÁRIA E ZOOTECNIA

CAMPUS DE BOTUCATU

\title{
SUPLEMENTAÇÃO DE ANTICORPOS POLICLONAIS OU MONENSINA SÓDICA SOBRE O COMPORTAMENTO INGESTIVO E DESEMPENHO DE BOVINOS BRANGUS E NELORE CONFINADOS
}

TAENNA MARTINS MARIANI

Dissertação apresentada ao Programa de Pós-Graduação em Zootecnia como parte das exigências para obtenção do título de Mestre. 
UNIVERSIDADE ESTADUAL PAULISTA

FACULDADE DE MEDICINA VETERINÁRIA E ZOOTECNIA

CAMPUS DE BOTUCATU

\title{
SUPLEMENTAÇÃO DE ANTICORPOS POLICLONAIS OU MONENSINA SÓDICA SOBRE O COMPORTAMENTO INGESTIVO E DESEMPENHO DE BOVINOS BRANGUS E NELORE CONFINADOS
}

\author{
TAENNA MARTINS MARIANI \\ Médica Veterinária
}

ORIENTADOR: Prof. Dr. MÁRIO DE BENI ARRIGONI

Dissertação apresentada ao Programa de Pós-Graduação em Zootecnia como parte das exigências para obtenção do título de Mestre. 


\section{Dedicatória}

Aos meus pais, MAURO E SUELY por tudo que me proporcionaram, e pelas oportunidades que me foram dadas. Dedico esse trabalho também ao meu namorado, DANILO, que com toda paciência e dedicação me ajudou a realizá-lo, fica explícito aqui o meu muito obrigado! 


\section{Agradecimentos}

Em primeiro lugar gostaria de agradecer ao Prof. Dr. Mário De Beni Arrigoni, meu orientador, pela oportunidade, confiança, abertura, companheirismo, dedicação e atenção a tudo relacionado ao desenvolvimento dessa dissertação.

Às pessoas que me receberam tão calorosamente quando cheguei a Botucatu, Prof ${ }^{a}$. Dra. Cyntia Ludovico Martins, Danilo Domingues Millen e Rodrigo Dias Lauritano Pacheco por toda dedicação, companheirismo, ensinamentos, enfim, a todo apoio que vocês me deram.

Aos estagiários e colegas de mestrado que tanto me ajudaram nas cansativas observações: Luis Marcelo N. Sarti, Robson S. Barducci, Samira R. Baldin, João Paulo S. T. Bastos, Fernando S. Parra e João Ricardo Ronchesel, muito obrigado pela ajuda.

Aos funcionários do setor de Confinamento de Bovinos de Corte: Cido, Dinho, Claudemir e Sidnei pela dedicação e vontade constante de fazer com que tudo desse certo.

À Camas Incorporated Americana por fornecer sem custo nenhum para universidade o produto contendo o preparado de anticorpos policlonais. Um obrigado especial aos senhores Brad Mitteness e Scott Simplot.

À FAPESP pelo auxílio pesquisa concedido para condução deste estudo (processo 2007/58993-4) e ao CNPq pela bolsa de estudos concedida. 
SUMÁRIO

CAPÍTULO 1

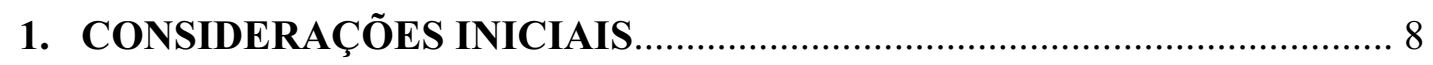

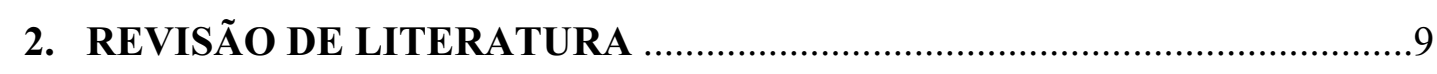

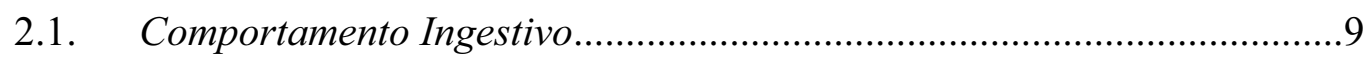

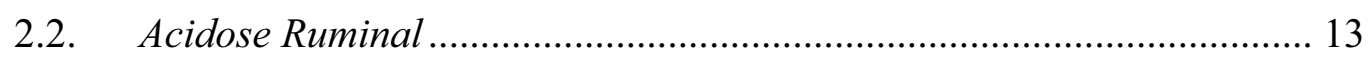

2.3. Aditivos Alimentares e Ionóforos. ...................................................... 17

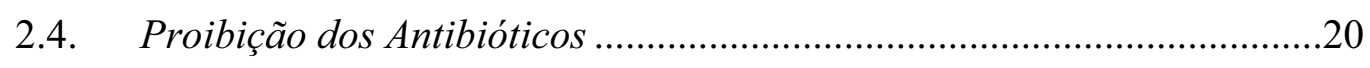

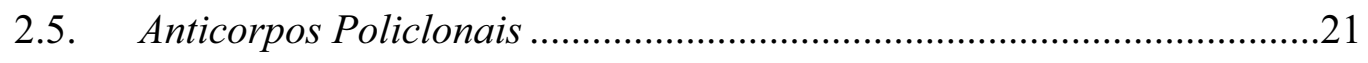

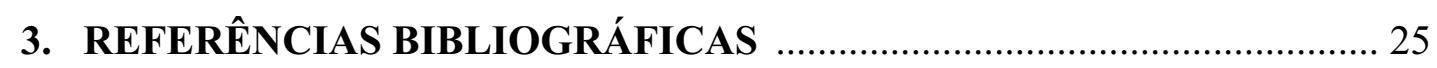

CAPÍTULO 2

SUPLEMENTAÇÃO DE ANTICORPOS POLICLONAIS OU MONENSINA SÓDICA SOBRE O COMPORTAMENTO INGESTIVO E DESEMPENHO DE BOVINOS BRANGUS E NELORES ALIMENTADOS COM DIETAS COM NÍVEIS CRESCENTES DE CONCENTRADO.

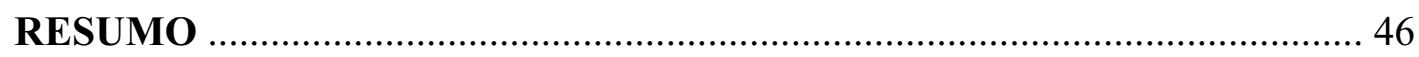

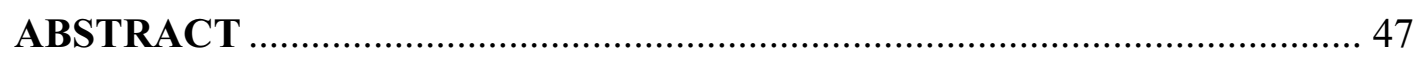

1. INTRODUÇÃ

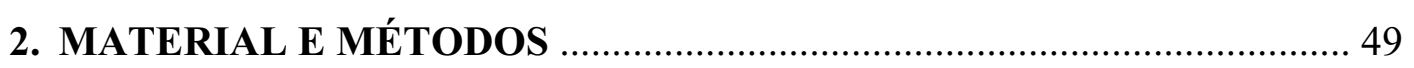

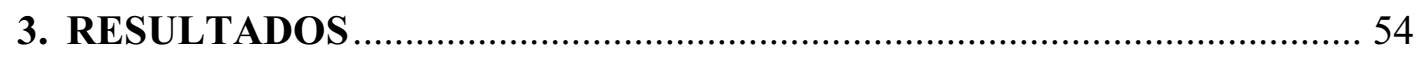

4. DISCUSSÃ

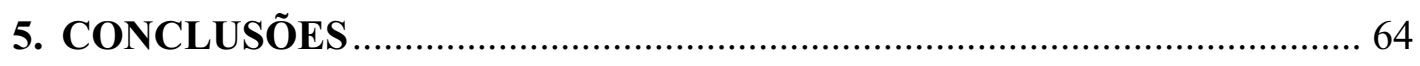

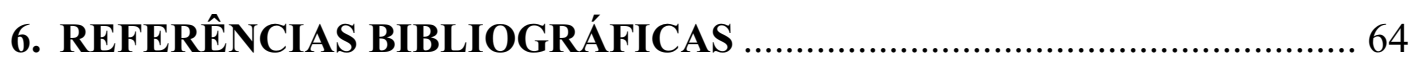

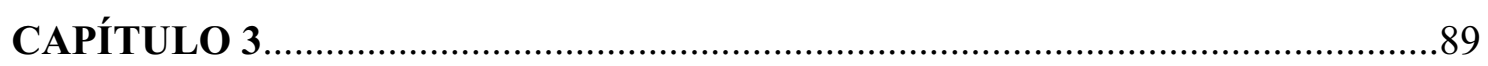

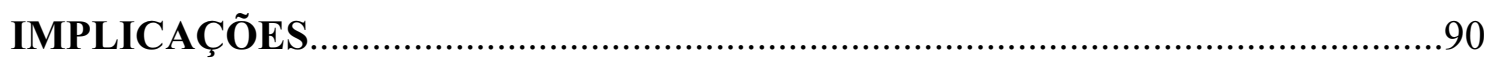


CAPÍTULO 1 


\section{CONSIDERAÇÕES INICIAIS}

Atualmente, com a intensificação dos sistemas de produção de bovinos decorrente tanto do aumento das exportações de carne bovina quanto da exigência do consumidor (Fapri, 2005), faz-se necessário recorrer a ferramentas que permitam pequenos ajustes no sistema para que se possa explorar o máximo potencial produtivo do animal.

Dentro dessas ferramentas, a manipulação da fermentação ruminal para melhorar o desempenho produtivo de bovinos e ruminantes em geral tem sido o objetivo de alguns nutricionistas por décadas (DiLorenzo, 2004). Essa manipulação da fermentação é um esforço que levou a extensa pesquisa na área de microbiologia ruminal nas últimas décadas, com o objetivo de controlar processos metabólicos no rúmen, atingindo assim utilização mais eficiente dos nutrientes (Nagaraja, 2003).

Alguns dos objetivos da manipulação da fermentação ruminal, segundo Nagaraja et al. (1997), incluem: melhorar processos benéficos e minimizar, alterar ou eliminar processos ineficientes que levem prejuízos tanto para os microorganismos do rúmen quanto para o hospedeiro.

A crescente resistência ao uso de antibióticos como promotores de crescimento direciona a busca por técnicas para melhorar os processos de fermentação ruminal (DiLorenzo, 2004).

Por exemplo, a União Européia, desde 2006, baniu o uso de ionóforos como promotores de crescimento (OJEU, 2003).

Aliado a isso, o país se destaca como o maior exportador de carne bovina do mundo, destinando 19,6\% de suas exportações para União Européia (ABIEC, 2008). De acordo com Millen et al. (2009), o Brasil confinou em 2008 cerca de 3.163 .750 animais, $547 \%$ a mais que seis anos atrás (Cavalcanti e Camargo, 2007). Com o aumento do número de animais confinados, aumentou também a inclusão de grãos nas dietas, o que e aumenta a eficiência do sistema de produção de carne bovina, mas pode levar à problemas de distúrbios digestivos como a acidose ruminal.

Dentro deste contexto, o estudo do comportamento ingestivo é de grande importância para bovinos mantidos em regime de confinamento, pois se utilizam diferentes dietas, grupos genéticos e aditivos alimentares gerando diferentes respostas 
em ingestão de matéria seca, conversão alimentar e ganho de peso (Krehbiel et al., 2003; DiLorenzo, 2004; Millen et al., 2007; Rodrigues et al., 2007) surgindo à necessidade de melhor entendimento do comportamento ingestivo de bovinos confinados, uma vez que este comportamento está intimamente relacionado com um desempenho técnico e econômico.

Logo, a descrição de um distúrbio metabólico como a acidose, um dos principais fatores que levam ao uso de antibióticos nos sistemas de produção de ruminantes, o comportamento ingestivo de bovinos e uma nova tecnologia em modificadores de fermentação ruminal, a imunização contra específicas populações de bactérias ruminais, serão discutidos neste trabalho. Imunização constitui num novo enfoque, mas têm potencial devido às características dos produtos, os quais são basicamente anticorpos. Estes são considerados de origem natural e com baixo risco de contribuir para resistência microbiana.

O objetivo dessa dissertação foi estudar os efeitos da suplementação de anticorpos policlonais e monensina sódica sobre o comportamento ingestivo e o desempenho de bovinos Brangus e Nelore confinados alimentados com dietas contendo níveis decrescentes de fibra.

\section{REVISÃO DE LITERATURA}

\subsection{Comportamento Ingestivo}

A etologia estuda o comportamento e as manifestações vitais dos animais em seu ambiente de criação ou em ambientes modificados pelo homem. O conhecimento do comportamento dos animais é essencial para a obtenção de condições ótimas de criação e alimentação, podendo, desta forma, obter-se o máximo de eficiência da produção (Swenson e Dukes, 1988).

Os ruminantes, respondem de forma diferente às dietas ou alimentos e ajustam o comportamento alimentar de acordo com suas necessidades nutricionais, sobretudo de energia.

Estudos sobre alimentação animal mostram que os animais podem reconhecer o valor energético dos alimentos e podem avaliar o custo energético de obter alimento, 
tendo escolha, os animais usualmente preferem continuar comendo aqueles alimentos com que estão acostumados.

No entanto, a exposição precoce aos tipos de alimentos que podem ser usados mais tarde na vida do animal, pode resultar no seu consumo imediato quando necessário. Isto é adaptativo, pois uma amostra muito limitada de alimentos novos permite ao animal aprender, por respostas fisiológicas e sentimentos associados de bemestar ou conforto, se o alimento é bom ou não (Graig, 1981).

Segundo Albright (1993), o estudo do comportamento ingestivo dos ruminantes tem sido usado com os objetivos de: 1) estudar os efeitos do arraçoamento ou quantidade e qualidade nutritiva de forragens sobre o comportamento ingestivo; 2) estabelecer a relação entre comportamento ingestivo e consumo voluntário; e 3) verificar o uso potencial do conhecimento a respeito do comportamento ingestivo para melhorar o desempenho animal.

Segundo Dado e Allen (1995), o comportamento ingestivo do animal é constituído pelos tempos de alimentação, ruminação, ócio, eficiência de alimentação e ruminação. O controle do consumo de alimentos está diretamente relacionado ao comportamento ingestivo (Chase et al., 1976). De acordo com Thiago et al. (1992), a quantidade de alimento consumido por um ruminante, em determinado período de tempo, depende do número de refeições nesse período e da duração e taxa de alimentação de cada refeição. Cada um desses processos é o resultado da interação do metabolismo do animal e das propriedades físicas e químicas da dieta, estimulando receptores da saciedade.

Geralmente, a ingestão ocorre de forma mais concentrada no período diurno, e a duração das refeições é muito mais variável que a duração dos períodos de ruminação ou descanso (Dulphy e Faverdin, 1987; Miranda et al., 1999).

O comportamento ingestivo varia conforme a consistência física da ração, pois pastagens são apreendidas com a língua e cortadas com os dentes incisivos inferiores. Em contrapartida os concentrados são apreendidos com a língua e sugados com a boca, devido a suas partículas serem pequenas, não havendo a necessidade de secções, embora ocorram movimentos mastigatórios (Albright, 1993). De acordo com Fischer et al. (2000), ruminantes em confinamento arraçoados duas vezes ao dia apresentam duas refeições principais após o fornecimento da ração (durante 1 a 3 horas), além de um 
número variável de pequenas refeições entre elas. Os períodos de ruminação e descanso entre as refeições, sua duração e seu padrão de distribuição são influenciados pelas atividades de ingestão (Deswysen et al., 1993; Fischer et al., 1997ab).

Animais estabulados gastam em torno de uma hora consumindo alimentos ricos em energia, ou até mais de seis horas, para fontes com baixo teor de energia. Da mesma forma, o tempo despendido em ruminação é influenciado pela natureza da dieta e, provavelmente, é proporcional ao teor de parede celular dos volumosos. Assim, quanto maior a participação de alimentos volumosos na dieta, maior será o tempo despendido com ruminação (Van Soest, 1994). Rações contendo alto teor de fibra em detergente neutro (FDN) promovem redução do consumo de matéria seca (MS) total, devido à limitação provocada pela repleção do rúmen-retículo.

Por outro lado, rações contendo elevados teores de concentrado e menores níveis de fibra também podem resultar em menor consumo de MS, uma vez que as exigências energéticas dos ruminantes poderão ser atingidas com menores níveis de consumo (Gonçalves et al., 2001). Burger et al. (2000) trabalhando com dietas com níveis crescentes de concentrado para bezerros holandeses, sem consumo de MS limitado pelo teor de fibra das dietas, verificaram tempos despendidos por refeição de 13,24 e 13,43 minutos em média, para os níveis de 45 a $60 \%$ de concentrado, respectivamente. Já o número médio de refeições ao dia foi 18,25 e 14,75, respectivamente.

Desta forma, o consumo de MS poderia ser aumentado com a maior inclusão de FDN na dieta, desde que este não limite fisicamente a ingestão dos animais.

Dado e Allen (1994) relataram à importância de mensurar o comportamento alimentar e a ruminação, a fim de verificar suas implicações sobre o consumo diário de alimentos. O tempo total de ruminação pode variar de quatro até nove horas, sendo dividido em períodos de poucos minutos a mais de uma hora. A atividade de ruminação pode ocorrer com o animal em pé ou deitado, sendo que esta última posição demonstra uma condição de conforto e bem estar.

De acordo com Van Soest (1994), o tempo despendido com ruminação é influenciado pela natureza da dieta, em que os alimentos concentrados reduzem o tempo de ruminação, enquanto forragens, com alto teor de parede celular, tendem a aumentálo. O teor de fibra foi positivamente relacionado ao tempo de ruminação (Welch e Swith, 1970; Dulphy et al.,1980) e ao tempo de ingestão (Beauchemin e Buchanan- 
Smith, 1989). O tamanho da partícula foi positivamente relacionado com a duração do tempo de ruminação e de mastigação (Welch e Smith, 1971; Dado e Allen, 1994). Segundo Welch e Hooper (1988), o tempo de ruminação é altamente correlacionado $(0,96)$ com o consumo de FDN em bovinos. Albright (1993) em experimento com vacas relatou para três níveis de FDN na dieta (26, 30 e 34\%), valores para os tempos despendidos em ruminação e total de mastigação de 334 e 558; 403 e 651; 414 e 674 $\mathrm{min} / \mathrm{dia}$; respectivamente.

Sarti et al. (2007) estudaram bovinos confinados com diferentes graus de sangue Zebu e relataram que à medida que o nível de concentrado na dieta aumentou e o teor de FDN diminuiu, animais com maior proporção de sangue europeu se mostram mais eficientes tanto na ruminação da matéria seca quanto do FDN.

Carvalho et al. (2000) verificaram elevação no período de ócio à medida que se diminuiu o teor de fibra das rações. Segundo Costa et al. (1983), o comportamento de ócio é considerado como o período em que os animais não estão comendo, ruminando ou ingerindo água. Esse tempo pode variar com as estações do ano, sendo maior durante os meses mais quentes (Marques, 2000).

Burguer et al. (2000), em estudos com bezerros recebendo cinco níveis diferentes de concentrado na dieta, que variaram de 30 a 90\%, relataram tempos de ócio de 655,2 a 1007,4 min/dia, sendo que o tempo médio em ócio aumentou linearmente com o aumento do nível de concentrado nas dietas.

Marques et al. (2005), observaram que os tempos de ócio foram semelhantes para os animais alojados individualmente $(215,10 \mathrm{~min} / \mathrm{dia})$ ou em baia coletiva $(217,00$ $\mathrm{min} / \mathrm{dia})$ e estes foram superiores aos alojados em dupla $(185,10 \mathrm{~min} / \mathrm{dia})$.

Outros fatores que alteram o comportamento ingestivo de bovinos de corte são a raça ou a composição genética, já que tem sido relatado por alguns autores melhor desempenho em confinamento de bovinos cruzados (com alguma proporção de sangue europeu) em relação a bovinos puros de raças Zebus (Cruz et al., 1995; Sherbeck et al., 1995; Krehbiel et al., 2000; Leme et al., 2000; Cucki, 2006; Ferrel et al., 2006; Millen et al., 2007). Vários autores também têm relatado consumo de MS inferior (Frisch e Vercoe, 1969; Rogerson et al.,1968; Ledger et al., 1970; Fox et al., 1988; Barbosa, 1998) e maior incidência de lesões ruminais (Millen et al., 2007) para bovinos puros de raças Zebu comparados com animais cruzados com alguma proporção de sangue 
europeu, quando estes são alimentados com dietas de alto concentrado. Assim sendo, a avaliação do comportamento ingestivo se torna importante para esclarecer a relação entre grupos genéticos e diferentes tipos de dietas em sistemas de alimentação de bovinos de corte em confinamentos.

\subsection{Acidose Ruminal}

O sucesso dos ruminantes pode ser largamente explicado pela habilidade destes em digerir materiais fibrosos. $\mathrm{O}$ fato de estes animais possuírem microorganismos que produzem enzimas que degradam fibra dá a eles uma vantagem competitiva em relação aos outros animais na natureza (Russel e Richlik, 2001). No entanto, altos níveis de produtividade não podem ser sustentados por forragens apenas e frequentemente grãos e seus subprodutos são utilizados na produção de ruminantes.

Com o crescente aumento da demanda de carne bovina no mercado internacional e projeções de maiores demandas nos próximos anos (Fapri, 2005 e European Comission, 2004), torna-se necessário elevar a produção para níveis mais intensificados e para isso faz-se necessário a inclusão na dieta de ruminantes alguns ingredientes, que aumentem o aporte de energia para o animal.

Em conseqüência disso, quando bovinos são submetidos a dietas de alto concentrado (grãos em geral) ou são rapidamente passados de uma dieta com alta proporção forragem para outra com alto teor de concentrado, uma série de processos fisiológicos são ativados resultando num distúrbio metabólico conhecido como acidose (DiLorenzo, 2004).

Acidose pode ser definida como a redução do conteúdo alcalino do fluído corporal em relação ao conteúdo ácido (Owens et al., 1998). Quando o suprimento de carboidratos não fibrosos é aumentado abruptamente, os ácidos graxos voláteis produzidos pelos microrganismos no rúmen e a proporção de ácido lático aumentam como resultado da maior taxa de fermentação. O lactato não está geralmente presente no rúmen em altas concentrações.

No entanto, quando o rúmen é suprido com altas quantidades de carboidratos não fibrosos, o acúmulo de ácido lático ocorrerá (Owens et al., 1998). O lactato apresenta menor constante de dissociação ácida $\left(\mathrm{pK}_{\mathrm{a}}\right)$ e portanto maior força que ácidos 
graxos voláteis comumente produzidos no rúmen (acetato, propionato, butirato, etc.), promovendo maior efeito na redução do pH ruminal (Dawson et al., 1997).

$\mathrm{O}$ processo de acidose se inicia quando o ruminante consome grandes quantidades de amido ou outros carboidratos rapidamente fermentáveis. A hidrólise do amido leva ao aumento da concentração de glicose ruminal, a qual normalmente é muito baixa, até o ponto aonde esta pode exceder a concentração de glicose sanguínea (Galyean e Rivera, 2003). O aumento da concentração de glicose ruminal causa várias conseqüências negativas no ambiente ruminal como: 1) o crescimento de microrganismos produtores de lactato, principalmente da bactéria Streptococcus bovis (Dawson et al., 1997); 2) aumento da osmolaridade (quantidade de sólidos dissolvidos no fluído ruminal), a qual colabora com a acidez ruminal inibindo a absorção de ácidos graxos voláteis do rúmen (Owens et al., 1998); e 3) crescimento de microrganismos coliformes e aminoácido descarboxilantes, os quais produzem endotoxinas que contribuem para o desenvolvimento de laminites (Galyean e Rivera, 2003).

O ácido lático é acumulado durante acidose como resultado da proliferação de microrganismos ruminais que fermentam glicose a lactato, os quais são insensíveis a $\mathrm{pH}$ reduzido. Por outro lado, a maior parte das bactérias utilizadoras de lactato são sensíveis a baixos valores de pH (Owens et al., 1998). Essa situação favorece a produção e o acúmulo de ácido lático no rúmen que é frequentemente observado quando ruminantes são abruptamente passados de dietas com alta proporção de forragem para outras com alto teor de concentrado. Se bovinos são gradualmente adaptados a dietas com alto teor de concentrado, o acúmulo de ácido lático é prevenido; no entanto, o pH ruminal poderá ainda permanecer baixo devido a maior produção de ácidos graxos voláteis (Nagaraja, 2003). O pH de 5,5 é considerado por alguns autores (Slyter, 1976; Nagaraja, 2003) a barreira, abaixo da qual, bactérias produtoras de lactato como Streptococcus bovis e Lactobacillus spp. proliferam. Simultaneamente, o crescimento de bactérias utilizadoras de lactato (Megasphera elsdenii e Selenomonas ruminantium) é inibido (Russel e Hino, 1985). Assim sendo, independentemente do tipo de dieta, quando o pH ruminal cai abaixo de 5,5; acúmulo de ácido lático é esperado.

Dois tipos de acidose podem afetar bovinos confinados: clínica e subclínica. Em acidose clínica, bovinos que consumiram grandes quantidades de carboidratos não fibrosos, como grãos, apresentaram maiores produções de ácidos graxos voláteis 
(Galyean e Rivera, 2003). A concentração de ácido lático ruminal também é abruptamnete aumentada com o aumento da produção de ácidos graxos voláteis, resultando em uma drástica redução do $\mathrm{pH}$ ruminal. Concentrações de ácido lático no rúmen maiores que $40 \mathrm{mM}$ (ambas as formas isômeras $\mathrm{D}$ e L) são consideradas reflexos de acidose clínica (Owens et al., 1998). O pH menor que 5,2 é considerado a barreira para acidose clínica (Owens et al., 1998; Galyean e Rivera, 2003). Mais detalhadamente, no momento que o $\mathrm{pH}$ ruminal cai abaixo de 5,2, o crescimento de bactérias Streptococcus bovis é inibido, mas bactérias do gênero Lactobacillus encontram ambiente favorável para se proliferar, preenchem este nicho e continuam a produzir ácido lático em pH menor que 5,2 (Russel e Hino, 1985). Em casos extremos, a acidose ruminal causa a migração de ácidos para a corrente sanguínea devido à diferença de osmolaridade entre o rúmen e o sangue, derrubando, desse modo, a capacidade do bicarbonato de tamponar o sangue (Galyean e Rivera, 2003).

No caso de acidose subclínica ou subaguda, ruminantes não mostram sintomas ou sinais externos da doença, mas com freqüência a ingestão de matéria seca e consequentemente o desempenho animal são diminuídos. $\mathrm{O}$ pH de 5,6 é considerado a barreira para acidose subclínica (Owens et al., 1998; Galyean e Rivera, 2003). Acidose subclínica ocorre mais frequentemente e a identificação de um animal doente dentro da baia se torna mais difícil mesmo ocorrendo severa redução no consumo de matéria seca. De acordo com Stock e Britton (1996), todos os animais submetidos a dietas com altos teores de concentrado vão passar por acidose subclínica no mínimo uma vez durante o confinamento.

A absorção de ácidos graxos voláteis pela remoção de ácidos não ionizados e pela troca de ácidos graxos ionizados por bicarbonato durante o processo de absorção (Stevens, 1970), ajuda a manter o $\mathrm{pH}$ ruminal próximo à neutralidade. Consequentemente, a redução da taxa de absorção de ácidos graxos voláteis leva à queda do $\mathrm{pH}$ do rúmen por duas razões: acúmulo de ácidos graxos voláteis no rúmen e redução da entrada de bicarbonato provindo do sangue para dentro do meio ruminal. Aproximadamente metade do bicarbonato que entra no rúmen vem da saliva durante mastigação e ruminação, e a outra metade chega ao rúmen vindo da corrente sanguínea na troca com os ácidos ionizados enquanto estes estão sendo absorvidos. Com dietas de alto concentrado e reduzida contribuição de saliva, maior proporção de bicarbonato 
deve ser derivada do sangue. Isso reduz os excessos de base no sangue e se o animal não conseguir restabelecer a homeostase, isso pode acarretar em acidose metabólica (Owens et al., 1998).

Faverdin e Bareille (1999) relataram que as concentrações de bicarbonato e excessos de base no sangue foram negativamente correlacionadas com a concentração ruminal de ácidos graxos voláteis quando altas quantidades de grãos de trigo foram adicionadas ao rúmen de vacas de leite canuladas. Esses resultados foram acompanhados de transitória redução no consumo de matéria seca. Outros estudos também têm reportado reduções nas concentrações sanguíneas de bicarbonato e excessos de base durante acidose subclínica em novilhos confinados. (Goad et al., 1998). Outras respostas do organismo dos ruminantes em decorrência de acidose metabólica seria a taxa respiratória compensada levando à baixos valores de pressão e total de gás carbônico e aumento na pressão e saturação de oxigênio sanguíneos (Hill, 1990). Sob condições normais, o pH do sangue é altamente regulado e raramente flutua, porque está saturado com bicarbonato. Durante acidose clínica, no entanto, a produção excessiva de ácidos pode exaurir a capacidade de o bicarbonato tamponar o sangue e então o pH sanguíneo pode diminuir (Owens et al., 1998). Den Hartog et al. (1989) e Jackson et al. (1992) observaram reduzidos pH, bicarbonato e pressão de gás carbônico no sangue quando novilhos confinados foram alimentados com dietas de teores elevados de concentrado. Outros eventos que acontecem simultaneamente estão associados com a diminuição do volume extracelular, resultando em desidratação, batimentos cardíacos inconstantes, diminuição da circulação sanguínea periférica, redução do fluxo de sangue para os rins, choque e morte (Huntington, 1988). Assim sendo, se o ruminante não for capaz de restabelecer a homeostase, o resultado pode ser a morte do animal.

Várias ferramentas de manejo e aditivos alimentares podem ser utilizadas com o intuito de prevenir ou controlar acidose, e a eficácia dessas ferramentas é dependente da extensão da doença e da natureza do produto. Tamponantes como o bicarbonato, óxido de magnésio e carbonato de cálcio foram adicionados a dietas para neutralizar ácidos nos anos 70 (Russell e Rychlik, 2001). No entanto, o efeito do bicarbonato sozinho como agente tamponante não é suficiente para conter acidose em bovinos confinados. Carbonato de cálcio e óxido de magnésio são mais efetivos em $\mathrm{pH}$ reduzidos; mas, seria necessário o fornecimento desses produtos várias vezes ao dia para se obter o efeito 
desejado de tamponamento ruminal, pois esses agem no rúmen no mesmo momento em que são consumidos, não restando, por exemplo, poder tampão suficiente no pico de produção de ácidos graxos voláteis que ocorre em geral quatro horas após a alimentação, o que torna o uso desses produtos inviáveis.

Indubitavelmente, o uso de ionóforos é um dos métodos mais efetivos para controle e prevenção da acidose, desde que o manejo alimentar do confinamento permita que o ionóforo mostre seu potencial.

\subsection{Aditivos Alimentares e Ionóforos}

Aditivo alimentar é um termo genérico aplicado a compostos de várias origens geralmente incluídos nas dietas em pequenas proporções e formulados para melhorar o desempenho e saúde em bovinos, suínos e aves (DiCostanzo et al., 1996). Em alguns, os efeitos primários são para melhorar o ganho de peso diário e a conversão alimentar, enquanto que em outros são para induzir ciclicidade, reduzir abscessos hepáticos ou controlar problemas de casco. Alguns aditivos alimentares têm efeitos benéficos secundários, os quais incluem redução de acidose, cocciodioses e timpanismos.

Em nutrição de ruminantes é bem entendido que o desempenho animal é fortemente influenciado pelo tipo e qualidade da fermentação ruminal. Processos fermentativos liderados por microorganismos rendem diferentes tipos de produtos finais dependendo do: 1) tipo de dieta, 2) populações de microorganismos predominantes, 3) processamento dos ingredientes, e 4) presença ou não de aditivos alimentares. Devido à importância desses aditivos alimentares em melhorar a saúde do rúmen e favorecer a fermentação ruminal, a manipulação bem feita desses produtos é de vital importância para o nutricionista de bovinos. No entanto, alguns aditivos alimentares para bovinos de corte como os probióticos, contam com resultados ainda inconsistentes no que diz respeito à melhora do desempenho e da saúde ruminal. Em alguns estudos os probióticos melhoraram o desempenho e preveniram quadros de acidose ruminal (Rust et al., 2000; Krehbiel et al., 2003); mas em outros os probióticos não tiveram efeito (Ghorbani et al., 2002; Beauchemin et al., 2003; Elam et al., 2003). Resultados dos efeitos de diferentes tipos de probióticos sobre bovinos de corte são mostrados nas Tabelas 1 e 2 . 
De todos os aditivos alimentares, ionóforos são os mais comumente usados na indústria de bovinos de corte. Ionóforos são agentes químicos que aumentam a permeabilidade de membranas lipídicas biológicas ou artificiais a íons específicos. A maior parte dos ionóforos são pequenas moléculas orgânicas que agem como carreadores móveis dentro das membranas ou formam um canal íon permeável através das mesmas. São quimicamente classificados como poliéteres antibióticos (Hironiko et al., 1994), e muitos deles agem como agentes causadores de "curto circuito" no gradiente de prótons através das membranas das mitocôndrias. Os ionóforos mais usados pela indústria de bovinos de corte, atualmente, incluem salinomicina, MON e lasalocida.

Alguns dos efeitos benéficos dos ionóforos incluem: aumento da produção de propionato ruminal pela modificação dos padrões de fermentação (Perry et al., 1976); redução das perdas de energia devido à redução da produção de metano (Russell e Strobel, 1989); prevenção de desordens digestivas como a acidose (Owens et al., 1998); redução da proteólise ruminal (Bergen e Bates, 1984); diminuída desaminação no rúmen (Chalupa, 1980); e aumento do fluxo de lipídeos para o intestino delgado (Clary et al., 1993).

Todos os processos citados acima levam ao aumento do desempenho animal pelo aumento da eficiência do metabolismo energético dentro do rúmen, melhorando o metabolismo de nitrogênio e reduzindo desordens digestivas em confinamento, especialmente acidose lática e timpanismo (Bergen e Bates, 1984). O aumento da proporção molar de ácido propiônico no rúmen com a redução na proporção de ácidos acético e butírico ocorre quando ionóforos são oferecidos (Nagaraja et al., 1981). Propionato é o único ácido graxo volátil que pode ser convertido à glicose, a qual então pode ser utilizada como fonte de energia pelos ruminantes. A redução na relação acetato/propionato leva a menor incremento calórico pois o ácido acético gera mais calor quando é produzido se comparado ao ácido propiônico (Bergen e Bates, 1984). A redução na produção de metano também melhora a retenção de carbono e energia pelo hospedeiro (Chalupa, 1980), pois a perda de energia devido à produção de metano pode representar mais que $12 \%$ da energia dos ingredientes. Os ionóforos podem reduzir essas perdas em mais de 30\% (Russel e Strobel, 1989). 
A melhora no metabolismo do nitrogênio em ruminantes alimentados com ionóforos poderia ser explicada em parte pelo efeito de diminuição da degradação de proteína. Esses achados são suportados por observações de mais baixas concentrações ruminais de amônia em bovinos alimentados com monensina (Chalupa, 1980). O fato de a concentração de amônia ser reduzida poderia ser causado pela redução de enzimas proteolíticas e deaminativas ou pelo efeito direto sobre as atividades de proteases e deaminases (Bergen e Bates, 1984). Aumentos de 22 a 55\% na quantidade de proteína não degradável no rúmen foram observadas (Bergen e Bates, 1984) em cinco estudos quando MON foi oferecida.

A suplementação com ionóforos leva a uma marcante redução na população de microrganismos gram positivos, os quais são os principais produtores de lactato no rúmen (Wallace e Chesson, 1996). Um estudo demonstrou que poliéteres ionóforos, monensina e lasalocida, foram efetivos em prevenir acidose lática em bovinos alimentados com dietas a base de grãos ou solução de glicose (Nagaraja et al., 1981). Nesse estudo, a alimentação com um ou outro ionóforo foi eficaz sobre o $\mathrm{pH}$ ruminal e preveniu o acúmulo de ácido lático.

No entanto, a lasalocida além de demonstrar efeito de controle sobre o $\mathrm{pH}$ ruminal, inibiu mais severamente o crescimento de várias cepas de Streptococcus bovis quando comparada a monensina. Dennis et al. (1981) testaram o efeito de doses crescentes de lasalocida e monensina sobre as populações das bactérias maiores produtoras e utilizadoras de lactato no rúmen. Bovinos alimentados com monensina ou lasalocida apresentaram reduções nas populações das bactérias que mais produzem lactato no rúmen enquanto as populações das bactérias que mais utilizam ácido lático no rúmen não foram afetadas.

Monensina na concentração de $33 \mathrm{mg} / \mathrm{kg}$ de matéria seca, tilosina na concentração $11 \mathrm{mg} / \mathrm{kg}$ de matéria seca ou ambos foram fornecidos a novilhos consumindo dietas de alto grão para determinar os efeitos sobre o ganho de peso diário e a eficiência alimentar (Potter et al., 1985). A suplementação com monensina melhorou a eficiência alimentar e reduziu a ingestão de matéria seca, mas não teve efeito sobre a incidência de abscesso hepático. Por outro lado, a suplementação com tilosina aumentou o ganho de peso diário e melhorou a eficiência alimentar sem afetar a ingestão de matéria seca. Bovinos alimentados com tilosina apresentaram reduzida incidência de 
abscesso hepático ( 9 vs. 27\% para bovinos suplementados ou não com tilosina, respectivamente). Estão mostrados nas Tabelas 3 e 4 mais alguns resultados dos efeitos dos ionóforos sobre bovinos de corte.

\subsection{Proibição dos Antibióticos}

Ionóforos como a monensina e lasalocida são classificados pelo FDA (Foods and Drugs Administration) como antibióticos. Organizações como a NCBA (National Cattlemans Beef Association) americana, fazem esforços para re-classificá-los como ionóforos, baseado no fato que estes não têm função terapêutica quando usado nas dietas de bovinos e não são usados como agentes terapêuticos em medicina humana. Grupos científicos e os meios de comunicação estão questionando o uso de antibióticos em dietas de animais porque acham que estes tipos de antibióticos podem contribuir para o desenvolvimento de resistências, causando riscos para saúde humana.

Estatísticas mostram que, em geral, aproximadamente um terço de todos antibióticos produzidos são usados em produção animal. A maioria dos antibióticos produzidos é usada em medicina humana (Hardy, 2002). A Suécia baniu todos os antibióticos promotores de crescimento em 1996, tornando este país o pioneiro na Europa a ter esta experiência. Observações feitas há alguns anos após a proibição confirmaram o aumento de incidência de algumas doenças e levaram ao uso de altas doses ou ao emprego dos mais potentes produtos terapêuticos levando a uma produção animal menos eficiente. Após a Suécia, mais algumas proibições específicas ocorreram na Europa, mas os resultados dessas proibições sobre a emergência de organismos resistentes a antibióticos ou sobre a eficiência da produção animal, não são conhecidos ainda.

Hardy (2002) em revisão sobre o problema do uso de antibióticos em produção animal, postulou que deverá haver um balanço entre os prós e contras sobre o uso de promotores de crescimento à medida que eles permitirem produção de alta qualidade e baixo custo da carne, para alimentar a crescente população mundial com um pequeno risco de bactérias humanas desenvolverem resistência. Outros autores discordam disso; eles acreditam que saúde humana e segurança alimentar são mais importantes que uma eficiente produção animal (McDermott et al., 2002). Salyers (2002) concluiu que a pressão para regular o uso de antibióticos será maior assim que o público perceba que 
muitos dos antibióticos usados na agricultura e pecuária levam a cruzada seleção de bactérias resistentes a antibióticos frequentemente usados em humanos. A percepção negativa criada por antibióticos sendo oferecidos a animais, apesar da falta de evidência científica, poderia ser suficiente para retirar os antibióticos da pecuária.

Por isso, diante dos resultados inconsistentes dos probióticos em bovinos confinados e da eventual proibição ao uso de antibióticos em dietas de ruminantes surge a necessidade de se buscar desde já novas alternativas para um eventual substituto para os ionóforos, o qual apresente, no mínimo, o mesmo potencial e economicidade, mas sem restrições por parte de alguns mercados consumidores, como o europeu. Buscar uma nova alternativa de aditivo alimentar, que promova uma fermentação ruminal mais eficiente e favoreça o desempenho dos animais, com resultados satisfatórios e economicidade surge como uma nova área a ser explorada no Brasil, que destina 19,6\% de sua produção de carne bovina para o mercado europeu, onde desde 2006 ionóforos têm seu uso proibido como promotores de crescimento (OJEU, 2003).

\subsection{Anticorpos Policlonais}

Uma das alternativas para substituir os ionóforos e os antibióticos é a imunização. O conceito de imunização como ferramenta para atingir maior eficiência na fermentação ruminal e assim melhorar o desempenho animal é relativamente recente (Shu et al., 1999; Gill et al., 2000; DiLorenzo et al., 2006; Millen et al., 2007; Blanch et al., 2009).

A base desse mecanismo é o reconhecimento de corpos estranhos no organismo (antígenos), ativação dos leucócitos e engajamento do mecanismo efetor direto para remoção do patógeno. Quando os macrófagos da corrente sanguínea do hospedeiro encontram moléculas estranhas (antígenos) estes respondem englobando-as. Este evento é mediado pelas células $\mathrm{T}$, que estabelecem uma corrente de respostas resultando na estimulação das células B. As células B produzem proteínas chamadas anticorpos, os quais se ligam as moléculas estranhas. Esta ligação entre anticorpo e antígeno causa a destruição do invasor por fagocitose (Goldsby et al., 2000).

$\mathrm{O}$ animal escolhido para servir de produtor destes anticorpos foi a galinha. As explicações para isso são relativamente simples. O sistema imune de aves difere dos mamíferos em vários aspectos. Um dos aspectos mais distintos no sistema imune das 
aves é a imunidade passiva para os descendentes, aonde nos mamíferos é feita através da placenta ou do colostro e nas aves a proteção vêm através dos componentes líquidos do ovo (Schade et al., 2001). Enquanto o ovo está ainda no ovário, galinhas transferem suas imunoglobulinas séricas Y (IgY) para a gema do ovo. À medida que o ovo passa pelo oviduto, IgM e IgA são adicionados a albumina (Schade et al., 2001).

Anticorpos $\operatorname{IgG}$ de galinhas imunizadas são transportados eficientemente e acumulados na gema do ovo (Shimizu et al., 1988). Altos níveis de atividade dos anticorpos podem ser mantidos por imunização periódica, fazendo com que a produção de IgY de ovos de galinhas imunizadas seja economicamente viável (Shimizu et al., 1988 e Lee et al., 2002). A estabilidade de IgY obtida em galinhas imunizadas provou ser resistente ao congelamento, ácido, calor e proteólise, indicando que este composto pode ter grande potencial como aditivo alimentar (Shimizu et al., 1988), onde a atividade da IgY foi testada por aglutinação de culturas vivas de bactérias alvo.

Além disso, a especificidade de IgY contra E. coli foi testada desafiando a aglutinação com IgY não específico (provindo de galinhas não imunizadas); mas nenhuma aglutinação foi observada. Congelamento ou congelamento a seco também não afetaram a atividade dos anticorpos. IgY permaneceu ativa a $\mathrm{pH}$ em torno de 4; mas em pH menor que 4 foi inativada devido a mudanças na conformação do anticorpo, porém nenhuma avaria nos polipeptídios foi observada. Susceptibilidade a proteólise por enzimas gastrointestinais foi testada utilizando-se digestões com pepsina, tripsina e quimiotripsina. Apesar do fato de moléculas de anticorpo terem sido partidas pela pepsina e tripsina em pequenos polipeptídios, a atividade de ligação e aglutinação celular permaneceu inalterada. No entanto, a digestão de quimiotripsina não produziu nenhuma alteração na molécula de IgY.

Pesquisas prévias conduzidas por Shimizu et al. (1992) demonstraram que anticorpos de gemas de ovos apresentaram similar estabilidade quando comparados a anticorpos de mamíferos. Ikemori et al. (1997) concluíram que gemas de ovos em pó providos de galinhas imunizadas contra coronavirus bovino apresentaram maior potencial preventivo que colostro em pó de vacas imunizadas, promovendo assim uma alternativa para imunização passiva contra o coronavírus bovino em bezerros.

Resumindo, o mecanismo de formação do produto com anticorpos para o uso na alimentação dos bovinos se dá da seguinte maneira: galinhas são vacinadas com 
pequenas doses dos imunogenes de bactérias ruminais ( $S$. bovis, F. necrophorum e várias cepas de bactérias proteolíticas) e logo estas devolvem anticorpos específicos contra essas bactérias. Esses anticorpos passam, através dos mecanismos fisiológicos das galinhas para a gema dos ovos. Essa gema do ovo é utilizada então para se fazer o produto com anticorpos específicos para eliminar do meio ruminal dos bovinos, bactérias cuja fermentação é indesejável (Shimizu et al., 1988).

Segundo DiLorenzo et al. (2006), a alimentação com preparados de anticorpos policlonais (PAP) contra Streptococcus bovis e Fusobacterium necrophorum teve sucesso em reduzir as populações dessas bactérias quando novilhos foram alimentados com dieta de alto grão. A alta especificidade do anticorpo foi observada porque o mesmo não afetou as populações de outras bactérias testadas.

No estudo de DiLorenzo et al. (2008), os anticorpos de aves preparados contra Streptococcus bovis e Fusobacterium necrophorum foram eficientes em aumentar o $\mathrm{pH}$ ruminal e diminuir a incidência de abscessos hepáticos, respectivamente, em dietas de alto grão, propiciando aos animais imunizados melhor ambiente para fermentação e desenvolvimento de microorganismos benéficos, já que $S$. bovis e $F$. necrophorum são as bactérias chave no desenvolvimento de acidose ruminal e abscessos de fígado, respectivamente.

Shu et al. (1999) e Gill et al. (2000) também constataram aumento no pH ruminal e diminuição na concentração de lactato no rúmen quando vacas fistuladas foram submetidas ao tratamento com PAP e alimentadas com dieta de $90 \%$ de concentrado.

Blanch et al. (2009) estudando os efeitos de PAP na adaptação de novilhos à dietas de alto concentrado, relataram que os anticorpos foram efetivos em reduzir o risco de acidose, pois os animais suplementados, mesmo apresentando maior concentração total de ácidos graxos voláteis (147,1 vs. 132,9 $\mathrm{mM}$ ), apresentaram maior pH ruminal $(6,54$ vs. 5,95) e maior concentração de ácido acético $(90,3$ vs. $81,8 \mathrm{~m} M)$.

Trabalhando com vacas Girolandas canuladas, Marino et al. (2007) relataram que a suplementação com PAP foi tão efetiva em controlar o $\mathrm{pH}$ ruminal em dietas de alto concentrado quanto à $\mathrm{MON}(5,95$ vs. 5,99), sendo estes valores maiores estatisticamente que os apresentados pelo grupo controle $(5,65)$. Otero et al. (2007) observaram aumento na degradabilidade do FDN quando PAP foram administrados em 
comparação com a MON, o que poderia explicar o aumento na concentração de ácido acético obtida por Blanch et al. (2009).

De acordo com DiLorenzo et al. (2008), novilhos Angus alimentados com PAP contra $S$. bovis ou contra $F$. necrophorum apresentaram maiores pesos vivos finais que aqueles não alimentados ou alimentados com ambos os anticorpos. $\mathrm{O}$ efeito sobre o peso final pode ser atribuído ao maior ganho de peso diário observado em novilhos alimentados com um ou outro anticorpo. Não foram observados efeitos em relação à ingestão de matéria seca quando qualquer um dos anticorpos foi consumido. Entretanto, novilhos Angus alimentados com PAP contra $S$. bovis apresentaram melhora na eficiência alimentar, aumento no peso de carcaça quente e na espessura de gordura subcutânea e melhor classificação da carcaça quando comparados aos novilhos que não foram alimentados com anticorpos e novilhos alimentados com ambos os anticorpos $(S$. bovis e F. necrophorum).

Millen et al. (2009) estudaram bovinos jovens Brangus e Nelore confinados com dieta de alto concentrado e suplementados com MON ou PAP. Os animais suplementados com monensina apresentaram melhor desempenho que aqueles suplementados com PAP no período de terminação, quando a dieta continha $85 \%$ de concentrado, porém, considerando-se todo o período de confinamento não houve diferença no tocante ao desempenho entre os dois aditivos alimentares. Do mesmo modo, no estudo de Pacheco et al. (2008) a suplementação com PAP não afetou negativamente as características de carcaça.

Barducci et al. (2009) estudaram a inclusão ou não de MON e PAP (contra $S$. bovis, F. Necrophorum, Lactobacillus spp., Entoxinas, e E. Coli) em dietas de alto concentrado para bovinos jovens Brangus em confinamento. Os animais suplementados com MON apresentaram melhor conversão alimentar e maior ganho de peso diário que aqueles não suplementados com MON. A adição de PAP na dieta não melhorou o desempenho dos bovinos confinados. Neste mesmo estudo, Sarti et al. (2009) avaliaram a morfologia da parede ruminal e observaram que novilhos suplementados com MON apresentaram maior área de superfície absortiva por $\mathrm{cm}^{2}$ de parede ruminal que aqueles não suplementados com MON, o que pode indicar maior absorção de ácidos graxos voláteis e menor extensão de lesões. Por outro lado, a inclusão de PAP não alterou os parâmetros de morfologia ruminal. 
Millen et al. (2007), testando PAP contra as bactérias ruminais S. bovis, F. necrophorum e várias cepas de bactérias proteolíticas sobre o desempenho de bovinos jovens com diferentes graus de sangue Zebu, relataram que animais suplementados com PAP apresentaram similar ganho de peso diário, ingestão de matéria seca em quilos e eficiência alimentar quando comparados àqueles suplementados com MON. Já em porcentagem do peso vivo, animais suplementados com PAP consumiram mais alimento que aqueles suplementados com MON.

O aumento da ingestão de matéria seca devido ao uso de anticorpos na alimentação de bovinos confinados tem sido relatado por diversos autores (Shu et al., 1999; Gill et al., 2000; Shu et al., 2000). Estudos envolvendo o comportamento ingestivo de bovinos jovens confinados de diferentes grupos genéticos com objetivo de encontrar a razão para esse aumento do consumo em animais suplementados com PAP podem ser uma alternativa para se tentar explicar os mecanismos pelos quais os efeitos dos PAP são atingidos. Mais resultados sobre os efeitos dos PAP sobre bovinos de corte e ovinos são apresentados na Tabela 5.

Essa dissertação foi formatada de acordo com as normas do Journal of Animal Science.

\section{REFERÊNCIAS BIBLIOGRÁFICAS}

ABIEC. Associação Brasileira das Indústrias Exportadoras de Carne. Estatísticas: Volume das exportações entre Janeiro e Dezembro. ABIEC. 2008. Disponível em: <www.abiec.com.br $>$. Acesso em 01/03/2009.

ALBRIGHT, J. L. Nutrition and feeding calves: Feeding behavior of dairy cattle. J. Dairy Sci, v.76, n.2, p.485-498, 1993.

BARBOSA, P. F. Cruzamentos industriais e a produção de novilhos precoces. In: Simpósio sobre produção intensiva de gado de corte. CYRINO, J. E. P.; MENTEN, J. F. M.; LANNA, D. P. D. et al. (Eds.). Colégio Brasileiro de Nutrição Animal. p.100 - 114. 1998. 
BARDUCCI, R. S.; SARTI, L. M. N.; ARRIGONI, M. D. B. et al. Feedlot performance of Brangus cattle fed monensin or polyclonal antibody preparation against lactateproducing rumen bacteria. J. Anim. Sci, v.87, E-suppl.2, p.283-284, 2009.

BEAUCHEMIN, K. A.; BUCHANAN-SMITH, J. G. Effects of dietary neutral detergent fiber concentration and supplementary long hay on chewing activities and milk production of dairy cows. J. Dairy Sci, v.72, p.2288, 1989.

BEAUCHEMIN, K. A.; YANG, W. Z.; MORGAVI, D. P. et al. Effects of bacterial direct-fed microbials and yeast on site and extent of digestion, blood chemistry, and subclinical ruminal acidosis in feedlot cattle. J. Anim. Sci, v.81, p.1628$1640,2003$.

BERGEN, W. G.; BATES, D. B. Ionophores: Their effect on production efficiency and mode of action. J. Anim. Sci, v.58, p.1465-1483, 1984.

BLANCH, M., CALSAMIGLIA, S., DILORENZO, N. et al. Physiological changes in rumen fermentation during acidosis induction and its control using a multivalent polyclonal antibody preparation in heifers. J. Anim. Sci, v.87, p.1722-1730, 2009.

BRASHEARS, M. M.; GALYEAN, M. L.; LONERAGAN, G. H. et al. Prevalence of Escherichia coli O157:H7 and performance by beef feedlot cattle given Lactobacillus Direct-Fed Microbials. J. Food Prot. 66:748-754, 2003.

BURGER, P. J.; PEREIRA, J. C.; QUEIROZ, A. C. et al. Comportamento ingestivo em bezerros holandeses alimentados com dietas contendo diferentes níveis de concentrado. Revista Brasileira de Zootecnia, v.29, p.236-242, 2000.

CARVAlHO, S.; RODRIGUES, M. T.; BRANCO, R. H. et al. Comportamento ingestivo de cabras Alpinas em lactação submetidas a dietas com diferentes níveis de fibra em detergente neutro. In: REUNIÃO ANUAL DA SBZ, 37., 2000, Viçosa. Anais... Viçosa: Sociedade Brasileira de Zootecnia, [2000] (CD-ROM).

CAVAlCANTI, R. M.; CAMARGO, A. [2007]. Pesquisa top beef point em confinamentos. Beef Point. 2007. Disponível em: <http://www.beefpoint.com.br $>$ Acesso em: 05/09/2007. 
CHALUPA, W. Chemical control of rumen microbial metabolism. In: RUCKEBUSH, Y.; THIVEND, P. (Ed.) Digestive Physiology and Metabolism in Ruminants. AVI Publishing Co., Inc., Westport, CT, p.325, 1980.

CHASE, L. J.; WANGSNESS, P. J.; BAUMGARDT, B. R. Feeding behaviour of stress fed a complete mixed ration. J. Dairy Sci, v. 59, n.11, p.1923-1928. 1976.

CLARY, E. M.; BRANDT, R. T.; HARMON, D. L. et al. Supplemental fat and ionophores in finishing diets: Feedlot performance and ruminal digesta kinetics in steers. J. Anim. Sci, v.71, p.3115-3123, 1993.

COE, M. L.; NAGARAJA, T. G.; SUN, Y. D. et al. Effect of Virginiamycin on ruminal fermentation in cattle during adaptation to a high concentration diet and during an induced acidosis. J. Anim. Sci. 77:2259-2268, 1999.

COSTA, M. J. R. P.; MESQUITA, J. C.; JUNQUEIRA FILHO, A. A. Comportamento de vacas holandesas em pastagem. In: ENCONTRO PAULISTA DE ETOLOGIA, 1., Jaboticabal. Anais... Jaboticabal: UNESP/FCAVJ, p.251, 1983.

CRUZ, G. M.; TULLIO, R. R.; ESTEVES, S. N. et al. Peso ótimo de abate de machos cruzados para produção do bovino jovem. I - Desempenho em confinamento e características de carcaça. In: REUNIÃO ANUAL DA SOCIEDADE BRASILEIRA DE ZOOTECNIA, 32., 1995, Brasília. Anais... Viçosa: Sociedade Brasileira de Zootecnia, 1995. p.223.

CUCKI, T. O. A eficiência do sistema superprecoce com bovinos de diferentes proporções do genótipo Bos indicus. Botucatu: Universidade Estadual Paulista, 2006. 99p. Tese (Doutorado em Zootecnia) - Universidade Estadual Paulista, 2006.

DADO, R. G.; ALLEN, M. S. Variation in and relationships among feeding, chewing and drinking variables for lactating dairy caws. J. Dairy Sci, v.77, p.132, 1994.

DADO, R. G.; ALLEN, M. S. Intake limitations, feeding behavior, and rumen function of cows challenged with rumen fill from dietary fiber or inert bulk . J. Dairy Sci, v.78, n. 1, p. 118-133. 1995. 
DAWSON, K. A.; RASMUSSEN, M. A.; ALLISON, M. J. Digestive disorders and nutritional toxicity. In: HOBSON, P.N.; STEWART, C.S. (Ed.). The rumen microbial ecosystem. p.633-660, 1997.

DEN HARTOG, L. A.; SCHAMP, T. A. G.; MORS, R .A. B et al. The effect of dietary electrolyte balance on blood parameters and the performance of veal calves. Livest. Prod. Sci. v.21, p. 213, 1989.

DENNIS, S. M.; NAGARAJA, T. G.; BARTLEY, E. E. Effects of lasalocid or monensin on lactate-producing or using rumen bacteria. J. Anim. Sci, v.52, p.418-426, 1981.

DESWYSEN, A. G.; DUTILLEUL, P. A.; GODFRIN, J. P. Nycterohemeral eating and ruminanting patterns in heifers fed grass or corn silage: analysis by finite fourier transform. J. Anim. Sci, v.71, n.10, p.2739-2747, 1993.

DICOSTANZO, A.; CASSADY; J. M.; ZEHNDER, C. M. Utilization of approved feed additives in growing, finishing and replacement beef cattle diets. In: MINNESOTA NUTRITION CONFERENCE, 57., 1996, Bloomington, MN. Proceedings... Bloomington: University of Minnesota, p.81-96, 1996.

DILORENZO, N. Effects of feeding polyclonal antibody preparations against rumen starch and lactic-fermenting bacteria on target bacteria populations and steer performance. Saint Paul, Minnesota, USA: University of Minnesota, 2004, 101p. Master thesis submitted to the faculty of the graduate school of the University of Minnesota.

DILORENZO, N., DIEZ-GONZALEZ, F.; DICOSTANZO, A. Effects of feeding polyclonal antibody preparations on ruminal bacterial populations and ruminal $\mathrm{pH}$ of steers fed high-grain diets. J. Anim. Sci, v.84, p.2178-2185, 2006.

DILORENZO, N., DAHLEN, C. R.; DIEZ-GONZALEZ, F. et al. Effects of feeding polyclonal antibodies preparations on rumen fermentation patterns, performance, and carcass characteristics of feedlot steers. J. Anim. Sci, v.86, p.3023-3032, 2008. 
DULPHY, J. P.; REMONND, B.; THERIEZ, M. et al. Ingestive behavior and related activities in ruminants. In: CONNECTICUT, A. V. I. (ed). Digestive physiology and metabolism in ruminants. Publ. co., Inc. Wesport, p.103-122, 1980.

DULPHY, J. P.; FAVERDIN, P. L. L'ingestion alimentire chez les ruminants: modalités et phenomènes associés. Reproduction, nutrition, development, Paris, v.27, (1B), p.129-155, 1987.

ELAM, N. A., GLEGHORN, J. F., RIVERA, J. D. et al. Effects of live cultures of Lactobacillus acidophilus (strains NP45 and NP51) and Propionibacterium freudenreichii on performance, carcass, and intestinal characteristics, and Escherichia coli $\mathrm{O} 157$ shedding of finishing beef steers. J. Anim. Sci, v.81, p.2686-2698, 2003.

EUROPEAN COMISSION. Prospects for agricultural markets and income 2004 2011. Brussels, 2004.

FAPRI. World agricultural outlook. Iowa State University - University of Missouri Columbia, 2005.

FAVERDIN, P; BAREILLE, N. Lipostatic regulation of feed intake in ruminants. In: HEIDE, D. et al. (Eds). Regulation of feed intake. CAB International, p.82 $102,1999$.

FERRELL, C. L.; BERRY, E. D.; FREETLY, H. C. et al. Influence of genotype and diet on steer performance, manure odor, and carriage of pathogenic and other fecal bacteria. I. Animal performance. J. Anim. Sci, v.84, p.2515 - 2522, 2006.

FISCHER, V.; DESWYSEN, A. G.; AMOUCHE, E. et al. Efeitos da pressão de pastejo sobre o comportamento ingestivo e o consumo voluntário de ovinos em pastagem. Revista Brasileira de Zootecnia, v.26, n.5, p.1025-1031, 1997a.

FISCHER, V.; DESWYSEN, A. G.; DÈSPRES, L. et al. Comportamento ingestivo de ovinos recebendo dieta à base de feno durante um período de seis meses. Revista Brasileira de Zootecnia, v.26, n.5, p.1032-1038, 1997 b.

FOX, D. G.; SNIFFEN, C. J.; O'CONNOR, J. D. Adjusting nutrient requirements of beef cattle for animal and environmental variations. J. Anim. Sci, v.66, p.14751495, 1988. 
FRISCH, J. E.; VERCOE, J. E. Liveweight gain, food intake, and eating rate in Brahman, Africander, and Shorthorn x Hereford cattle. Australian Journal Research, v.20, p.1189, 1969.

GALYEAN, M. L.; NUNNERY, G. A.; DEFOOR, P. J. et al. 2000. Effects of live cultures of Lactobacillus acidophilus (strains 45 and 51) and Propionibacterium freudenreichii PF-24 on performance and carcass characteristics of finishing beef steers.

Online.

Available:

$<$ http://www.afs.ttu.edu/burnett_center/progress_reports/bc8.pdf $>$. Acessado 23 de Fevereiro de 2009.

GALYEAN, M. L.; RIVERA, J. D. Nutritionally related disorders affecting feedlot cattle. Can. J. Anim. Sci, v.83, p.13-20, 2003.

GHORBANI, G. R.; MORGAVI, D. P.; BEAUCHEMIN, K. A. et al. Effects of bacterial direct-fed microbials on ruminal fermentation, blood variables, and the microbial populations of feedlot cattle. J. Anim. Sci, v.80, p.1977-1986, 2002.

GILL, H. S.; SHU, Q.; LENG, R. A. et al. Immunization with Streptococcus bovis protects against lactic acidosis in sheep. Vaccine, v.18, p.2541-2548, 2000.

GOAD, D. W.; GOAD, C. L.; NAGARAJA, T. G. Ruminal microbial and fermentative changes associated with experimentally induced subacute acidosis in steers. J. Anim. Sci, v.76, p.234-241, 1998.

GOLDSBY, R. A.; KINDT, T. J.; OSBORNE, B. A. Kuby Immunology. $4^{\text {th }}$ ed. Chapter 1. W. H. Freeman and Company, New York, 2000.

GONÇALVES, A. L.; LANA, R. P.; RODRIGUES, M. T. et al. Padrão nictemeral do $\mathrm{pH}$ ruminal e comportamento alimentar de cabras leiteiras alimentadas com dietas contendo diferentes relações volumoso:concentrado. Revista Brasileira de Zootecnia, v.30, n.6, p.1886-1892, 2001.

HARDY, B. The issue of antibiotic use in the livestock industry: what have we learned? Animal Biotech. v.13, p.129-147, 2002.

HILL, L. L. Body composition, normal electrolyte concentrations and the maintenance of normal volume, tonicity, and acid-base metabolism. Pediat. Clin. North Am. v.37, p.241, 1990. 
HIROHIKO, A.; HIDEAKI, M.; KENICHI, H. et al. Improvement of chemical analysis of antibiotics. 21. Simultaneous determination of three polyether antibiotics in feeds using High-Performance Liquid Chromatography with fluorescence detection. J. Agric. Food Chem. v.42, p.112-117, 1994.

HUCK, G. L.; KREIKEMEIR, K. K.; DUCHARME, G. A. 2000. Effects of feeding two microbial additives in sequence on growth performance and carcass characteristics of finishing heifers. Disponível Online: $<$ http://www.oznet.ksu.edu/library/lvstk2/srp850.pdf $>$. Acessado 16 de Maio de 2009.

HUntington, G. B. Acidosis in the Ruminant Animal: Digestive Physiology and Nutrition. D. C. Church, ed. Prentice-Hall, Englewood Cliffs, p.474, 1988.

IKEMORI, Y.; UMEDA, M. O. K.; ICATLO JR., F. C. et al. Passive protection of neonatal calves against coronavirus-induced diarrhea by administration of egg yolk or colostrum antibody powder. Vet. Microbiol, v.58, p.105-111, 1997.

JACKSON, J. A.; HOPKINS, D. M.; XIN, Z. et al. Influence of cation-anion balance on feed intake, body weight gain, and humoral response of dairy calves. J. Dairy Sci, v.75, p.1281, 1992.

KREHBIEL, C. R.; RUST, S. R.; ZHANG, G. et al. Bacterial direct-fed microbials in ruminant diets: Performance response and mode of action. J. Anim. Sci, v.81 (E. Supp1.2), p.E120-E132, 2003.

KUNG, L.; HESSION, A. O. Preventing in vitro lactate accumulation in ruminal fermentations by inoculation with Megasphaera elsdenii. J. Anim. Sci, 73:250256, 1995.

LEE, E. N.; SUNWOO, H. H.; MENNINEN, K. et al. In vitro studies of chicken egg yolk antibody (IgY) against Salmonella enteritidis and Salmonella typhimurium. Poultry Sci., v.81, p.632-641, 2002.

LEDGER, H. P.; ROGERSON, A.; FREEMAN, G. R. Further studies on the voluntary food intake of Bos indicus, Bos taurus and crossbred cattle. Animal Production, v.12, p.425-432, 1970. 
LEME, P. R. et al. Desempenho em confinamento e características de carcaça de bovinos machos de diferentes cruzamentos abatidos em três faixas de peso. Revista Brasileira de Zootecnia, Viçosa, v.29, n.6, supl.2, p.2347 - 2353, 2000.

LILA, Z. A.; MOHAMMED, N.; YASUI, T. et al. Effects of a twin strain of Saccharomyces cerevisiae live cells on mixed ruminal microorganism fermentation in vitro. J. Anim. Sci, 82:1847-1854, 2004.

MARINO, C.; OTERO, W.; RODRIGUES, P. H. M. et al. Avaliação do preparado de anticorpos policlonais (PAP) nos parâmetros de fermentação ruminal em bovinos recebendo dietas de alto concentrado. In: Reunion Asociacion Latinoamericana de Produccion Animal (ALPA), 20., 2007, Cusco - Peru. Anais... Cusco, 2007, CDROM.

MARQUES, J. A. O stress e a nutrição de bovinos. Maringá: Imprensa universitária, p.42, 2000.

MCDERMOTT, P. F.; ZHAO, S.; WAGNER, D. D. et al. The food safety perspective of antibiotic resistance. Animal Biotech, v.13, p.71-84, 2002.

MILLEN, D. D.; PACHECO, R. D. L.; ARRIGONI, M. D. B. et al. Feedlot performance and rumen parakeratosis incidence in Bos indicus type bullocks fed high grain diets and monensin or polyclonal antibodies preparations against rumen bacteria. J. Anim. Sci, v.85, (supplement1), p.552, 2007.

MILlEN, D. D.; PACHECO; R. D. L.; ARRIGONI, M. D. B. et al. Feedlot performance of Nellore and Brangus cattle fed monensin or polyclonal antibody preparation against lactate-producing rumen bacteria. J. Anim. Sci, v.87, ESuppl.2, p.282, 2009.

MIRANDA, L. F.; QUEIROZ, A. C.; VALADARES FILHO, S. C. et al. Comportamento ingestivo de novilhas leiteiras alimentadas com dietas à base de cana-de-açúcar. Revista Brasileira de Zootecnia, v.28, p.614-620, 1999.

MOSELEY, W. M.; MEEUWSE, D. M.; BOUCHER, J. F. et al. A dose-response study of melengestrol acetate on feedlot performance and carcass characteristics of beef steers. J. Anim. Sci. 81:2699-2703, 2003. 
NAGARAJA, T. G.; AVERY, T. B.; BARTLEY, E. E. et al. Prevention of lactic acid acidosis in cattle by lasalocid or monensin. J. Anim. Sci, v.53, p.206-216, 1981.

NAGARAJA, T. G.; NEWBOLD, C. J.; VAN NEVEL, C. J. et al. Manipulation of ruminal fermentation. In: HOBSON P. N AND STEWART C. S (Ed.) The rumen microbial ecosystem, p.523-632, 1997.

NAGARAJA, T. G.; CHENGAPPA, M. M. Liver abscesses in feedlot cattle: A review. J. Anim. Sci. 76:287-298, 1998.

NAGARAJA, T.G.; SUN, Y.D.; WALLACE, N. et al. Effects of tylosin on concentrations of Fusobacterium necrophorum and fermentation products in the rumen of cattle fed a high-concentrate diet. Am. J. Vet. Res. 60:1061-1065, 1999.

NAGARAJA, T. G. Response of the Gut and Microbial Populations to Feedstuffs: The ruminant story in Proc. $64^{\text {th }}$ Minnesota Nutrition Conference. St. Paul, MN, p.64-77, 2003.

OJEU. Official Journal of the European Union. Regulation (EC) No 1831/2003 of the European Parliament and the Council of 22 of September of 2003 on Additives for Use in Animal Nutrition. Pages L268/29-L268/43 in OJEU of 10/18/2003.

OTERO, W. G.; MARINO, C. T.; ALVES, F. R. et al. Degradabilidade in situ da canade-açúcar e do farelo de soja sob a influência de preparado de anticorpos policlonais e monensina. In: V Congreso Internacional de Ganadaria de doble propósito, Cuzco - Peru. Trabalho aceito para publicação em Outubro de 2007.

OWENS, F. N.; SECRIST, D. S.; HILL, W. J. et al. Acidosis in cattle: A review. J. Anim. Sci, v.76, p.275-286, 1998.

PACHECO, R. D. L.; MILLEN, D. D.; ARRIGONI, M. D. B. et al. Evaluation of growth, carcass characteristics and meat tenderness of bullocks fed monensin or polyclonal antibodies against lactate producing rumen bacteria. J. Anim. Sci, v.86, p.200, 2008.

PERRY, T. W.; BEESON, W. M.; MOHLER, M. T. Effect of monensin on beef cattle performance. J. Anim. Sci, p.42, p.761-765, 1976. 
POTTER, E. L.; WRAY, M. I.; MULLER, R. D. et al. Effect of monensin and tylosin on average daily gain, feed efficiency and liver abscesses incidence in feedlot cattle. J. Anim. Sci, v.61, p.1058-1065, 1985.

RODRIGUES, R. B.; ARRIGONI, M. D. B.; RODRIGUES, E. et al. Evaluation of performance, tissue growth and meat tenderness of Nellore, Brangus and Canchim young bulls. J. Anim. Sci, v.85, Suppl.1, p.490-491, 2007.

ROGERSON, A.; LEDGER, H. P.; FREEMAN, G. H. Food intake and liveweight gain comparison of Bos indicus and Bos Taurus steers on a high plane of nutrition. Animal Production, v.10, p.373, 1968.

RUSSELL, J. B.; HINO, T. Regulation of lactate production in streptococcus bovis: a spiraling effect that contributes to rumen acidosis. J. Dairy Sci, v.68, p.1712, 1985.

RUSSELL, J. B.; STROBEL, H. J. Mini-Review: the effect of ionophores on ruminal fermentations. Appl. Environ. Microbiol, v.55, p.1-6, 1989.

RUSSELL, J. B.; RYCHLIK, J. L. Factors that alter rumen microbial ecology. Science v.292, p.1119-1122, 2001.

RUST, S. R., METZ, K., WARE, D. R. Effects of Bovamine3 rumen culture on the performance and carcass characteristics of feedlot steers. J. Anim. Sci, v.78, p.82, 2000.

SALYERS, A. A. An overview of the genetic basis of antibiotic resistance in bacteria and its implications for agriculture. Animal Biotech, v.13, p.1-5, 2002.

SARTI, L. M. N.; PACHECO, R. D. L.; MILLEN, D. D. et al. Evaluation of feeding behavior of young cattle from different genetic groups fed with high concentrate diets with different NDF levels. J. Anim. Sci, v.85, Suppl.1, p.552-553, 2007.

SARTI, L. M. N.; BARDUCCI, R. S.; MILLEN, D. D. et al. Rumen papillae measurements of feedlot cattle fed monensin or polyclonal antibody preparation against lactate-producing rumen bacteria. J. Anim. Sci, v.87, E-Suppl.2, p.284, 2009. 
SCHADE, R.; BEHN, I.; ERHARD, M. et al. (Eds). Chicken egg yolk antibodies, production and application. Chapter 1. Springer, Germany, 2001.

SHERBECK, J. A.; TATUM, J. D.; FIELD, T. G. Feedlot performance, carcass traits, and palatability traits of Hereford and Hereford x Brahman steers. J. Anim. Sci, v.73, p.3613-3620, 1995.

SHIMIZU, M.; FITZSIMMONS, R. C.; NAKAI, S. Anti-E. coli immunoglobulin Y isolated from egg yolk of immunized chickens as a potential food ingredient. J. Food Sci., v.53, p.1360-1366, 1988.

SHIMIZU, M.; NAGASHIMA, H.; SANO, K. et al. Molecular stability of chicken and rabbit immunoglobulin G. Biosci. Biotech. Biochem, v.56, p.270-274, 1992.

SHU, Q.; GILL, H. S.; HENNESSY, D. W. et al. Immunization against lactic acidosis in cattle. Research of Veterinary Science, v.67, p.65-71, 1999.

SHU, Q.; GILL, H. S.; LENG, J. B. et al. Immunization with a Streptococcus bovis vaccine administered by different routes against lactic acidosis in sheep. Vet. J., v.159, p.262-269, 2000a.

SHU, Q.; GILL, H. S.; LENG, J. B. et al. Immunization with a Streptococcus bovis vaccine administered by different routes against lactic acidosis in sheep. Vet. J., v.159, p.262-269, 2000b.

SLYTER, L. L. Influence of acidosis on rumen function. J. Anim. Sci, v.43, p.910-929, 1976.

STEVENS, C. E. Fatty acid transport through the rumen epithelium. In: A. T. Phillipson (Ed.) Physiology of Digestion and Metabolism in the Ruminant. Oriel Press, Newcastle upon Tyne, U.K, p.101-112, 1970.

STOCK, R. A.; LAUDERT, S. B.; STROUP, W. W. et al. Effects of monensin and monensin and tylosin combination on feed intake variation of feedlot steers. $\mathbf{J}$. Anim. Sci, v.73, p.39-44, 1995.

STOCK, R. A.; BRITTON, R. A. Acidosis. University of Nebraska. NebGuide. On line. Disponível: http://ianrpubs.unl.edu/animaldisease/g1047.htm, 1996. 
SWENSON, M. J.; DUKES, G. Fisiologia dos Animais Domésticos. Ed.Guanabara Koogan S. A. Rio de Janeiro. p.799, 1988.

SWINNEY-FLOYD, D.; GARDNER, B. A.; OWENS, F. N. et al. Effects of inoculation with either Propionibacterium strain P-63 alone or combined with Lactobacillus acidophilus strain LA53545 on performance of feedlot cattle. J. Anim. Sci. 77(Suppl. 1):77(Abstr.), 1999.

THIAGO, L. R. L.; GILL, M.; SISSONS, J.W. et al. Studies of conserving grass herbage and frequency of feeding in cattle. Brit. J. Nutr, v.67(3), p.339-336, 1992.

VAN SOEST, P. J. Nutitional ecology of the ruminant. 2.ed. Ithaca: Cornell University Press, 476p, 1994.

WALLACE, R. J.; CHESSON, A. Biotechnology in animal feeds and animal feeding. Part 1: ionophores, antibiotics and methane inhibitors in ruminants. Feed Compounder v.16:5, p.12-14, 1996.

WELCH, J. G.; SMITH, A. M. Forage quality and rumination time in cattle. J. Dairy Sci, v.53, p.797, 1970 .

WELCH, J. G.; SMITH, A. M. Physical stimulation of rumination activity. J. Anim. Sci, v.33, p.1118, 1971.

WELCH, J. G.; HOOPER, A. P. Ingestion of feed an water. In: CHURCH, D. C. (Ed). The ruminant animal: digestive physiology and nutrition. Englewood Ciffs: Reston, p.108-116, 1988. 


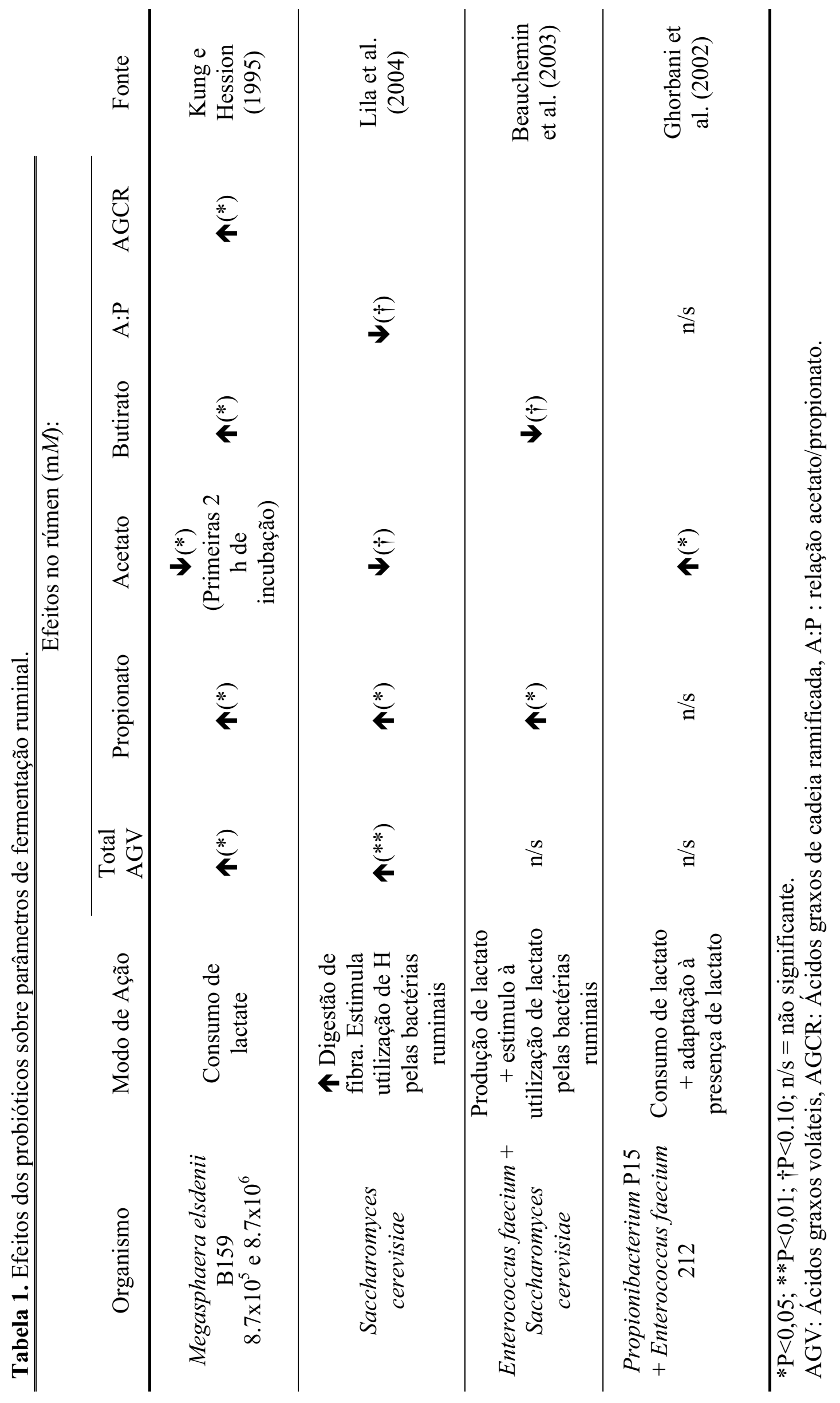


$\infty$

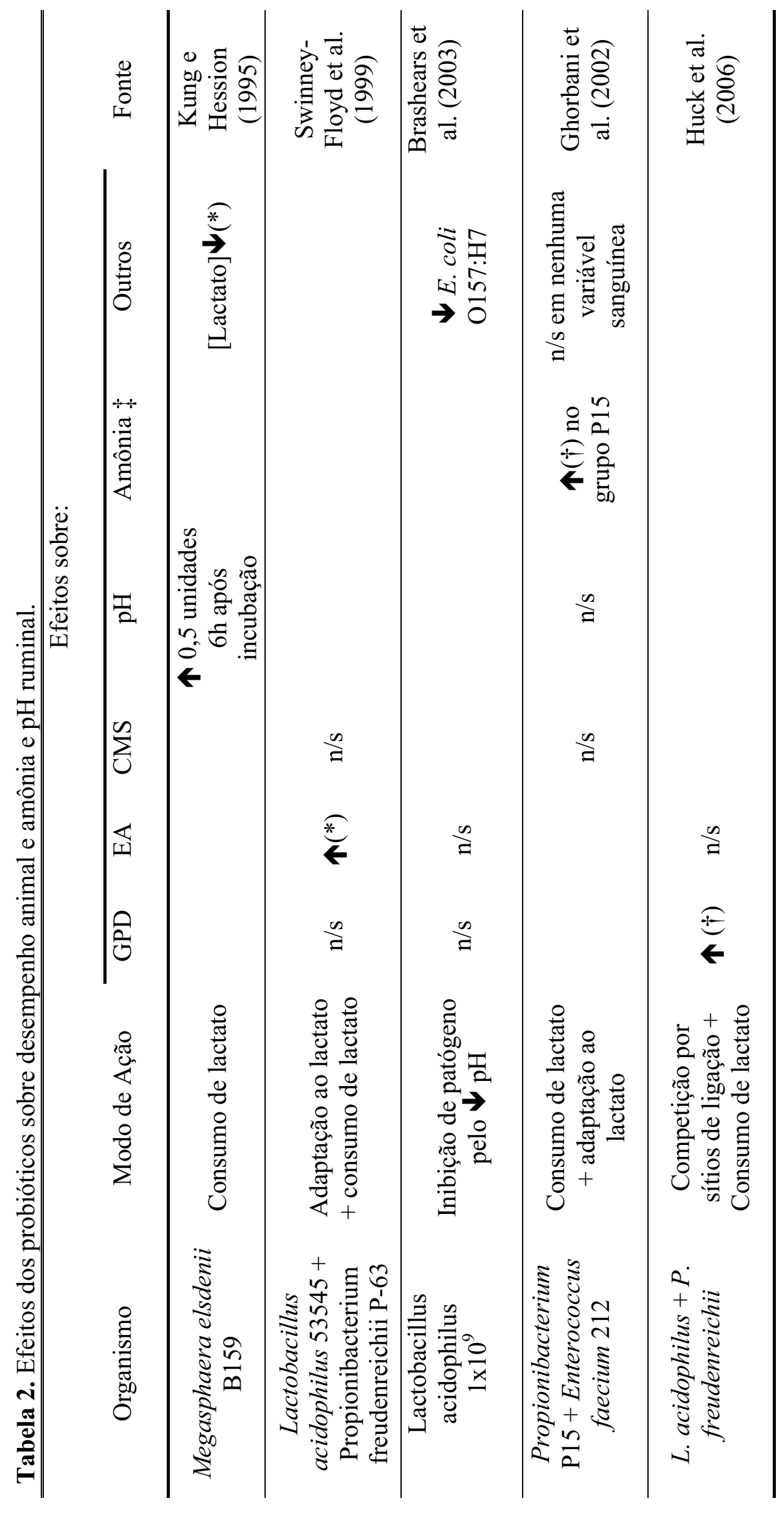


ले

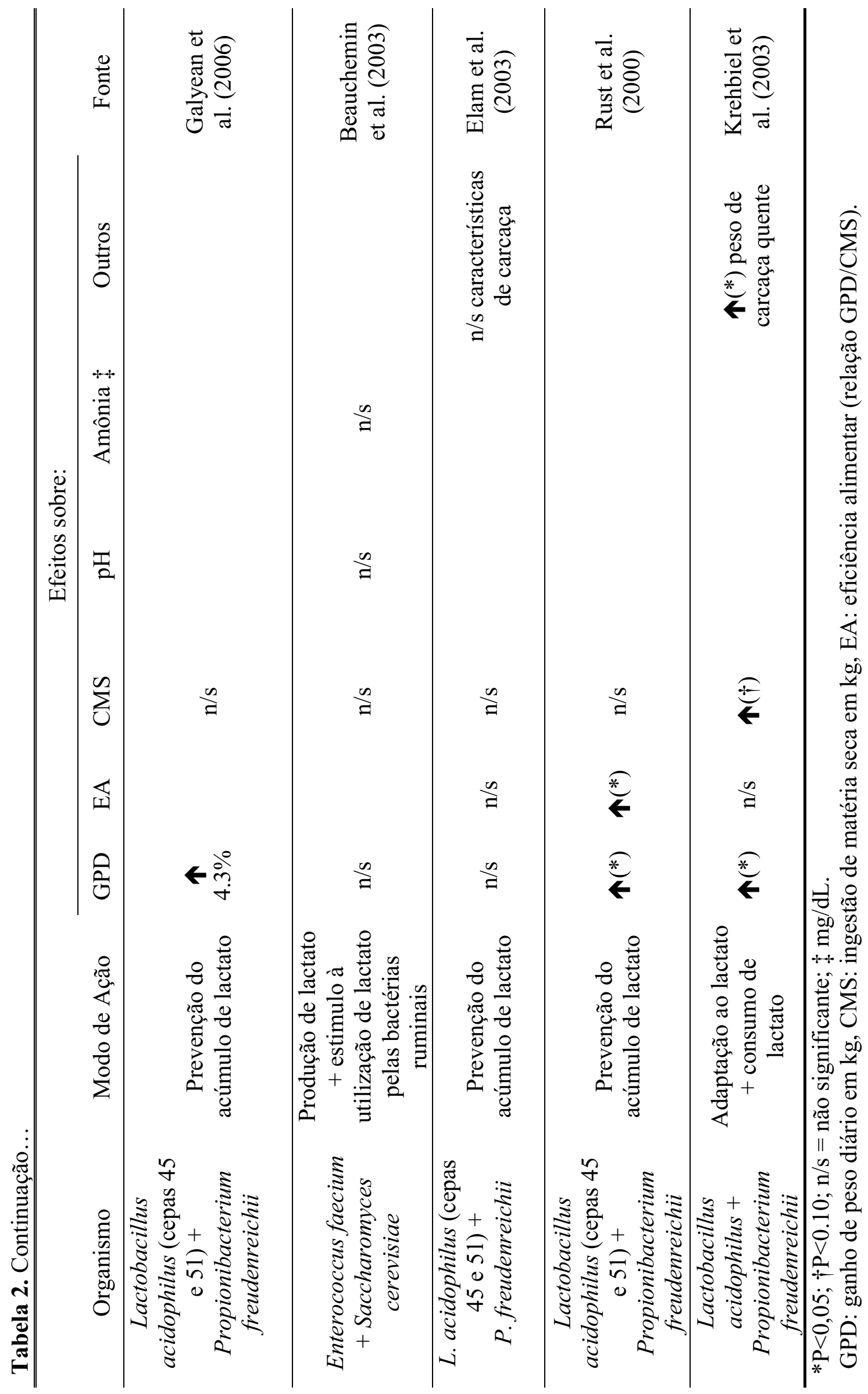


우

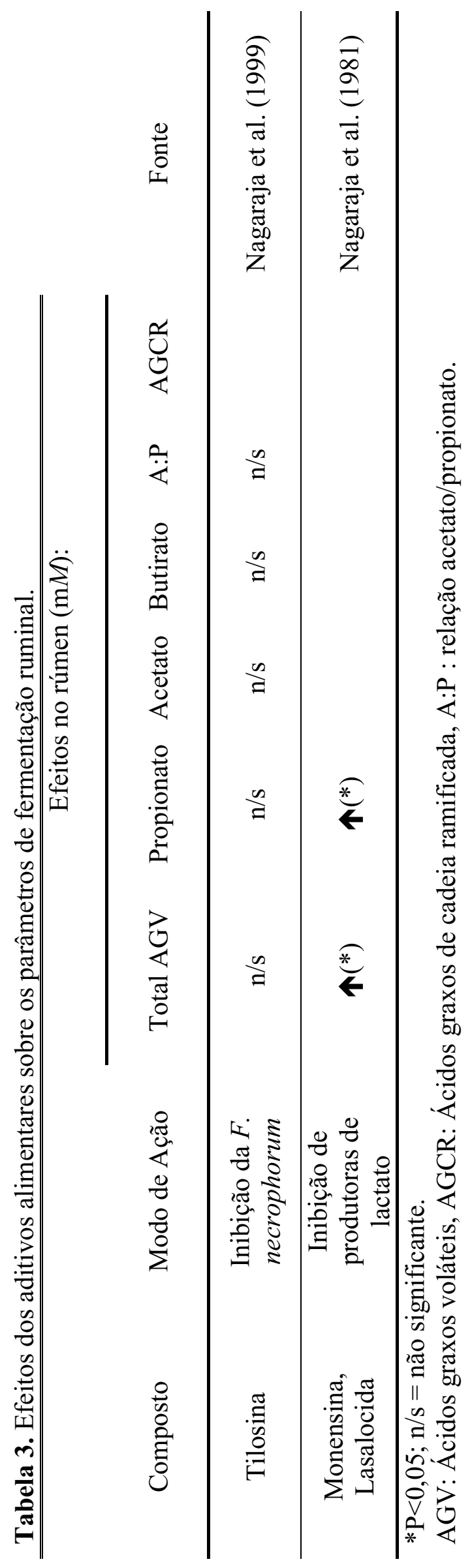




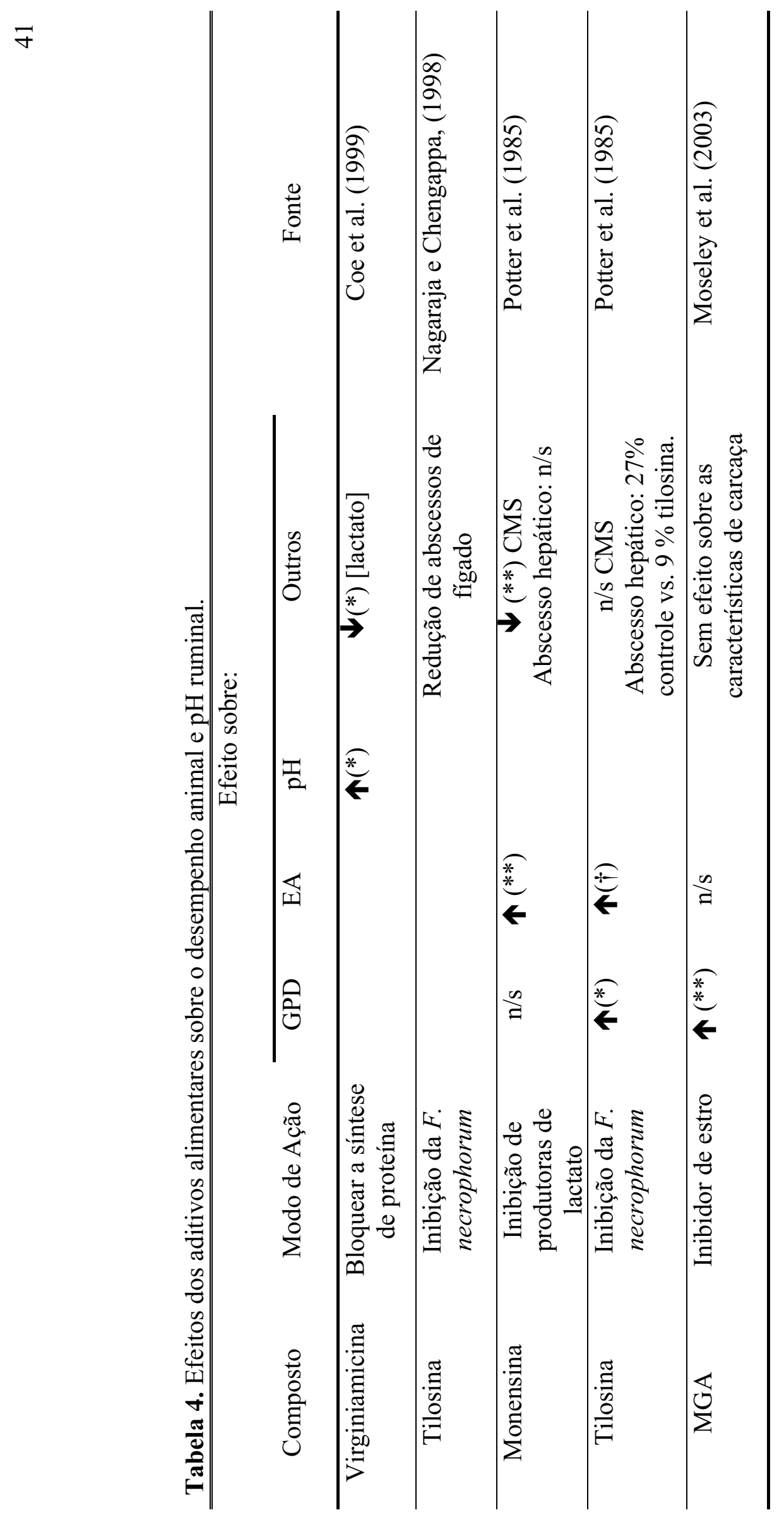




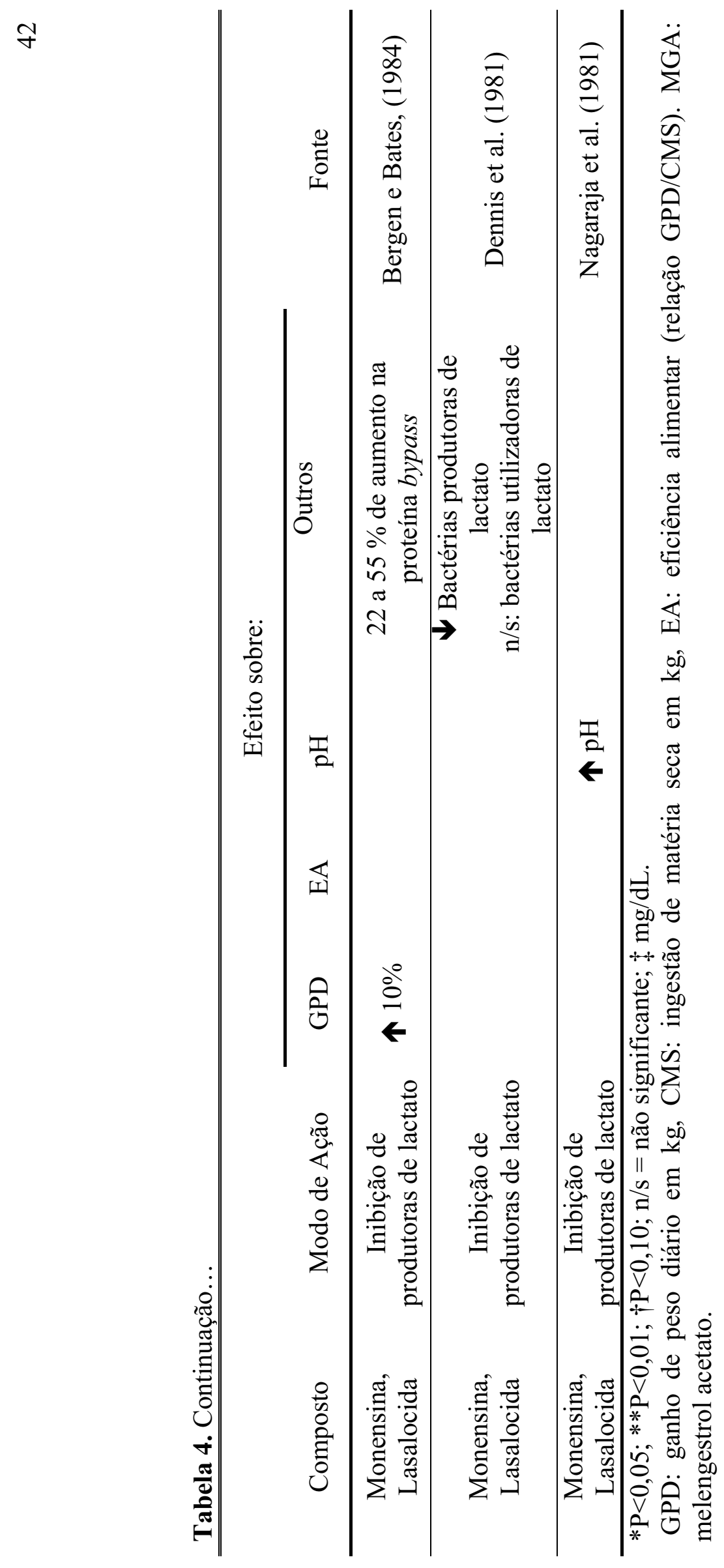


q

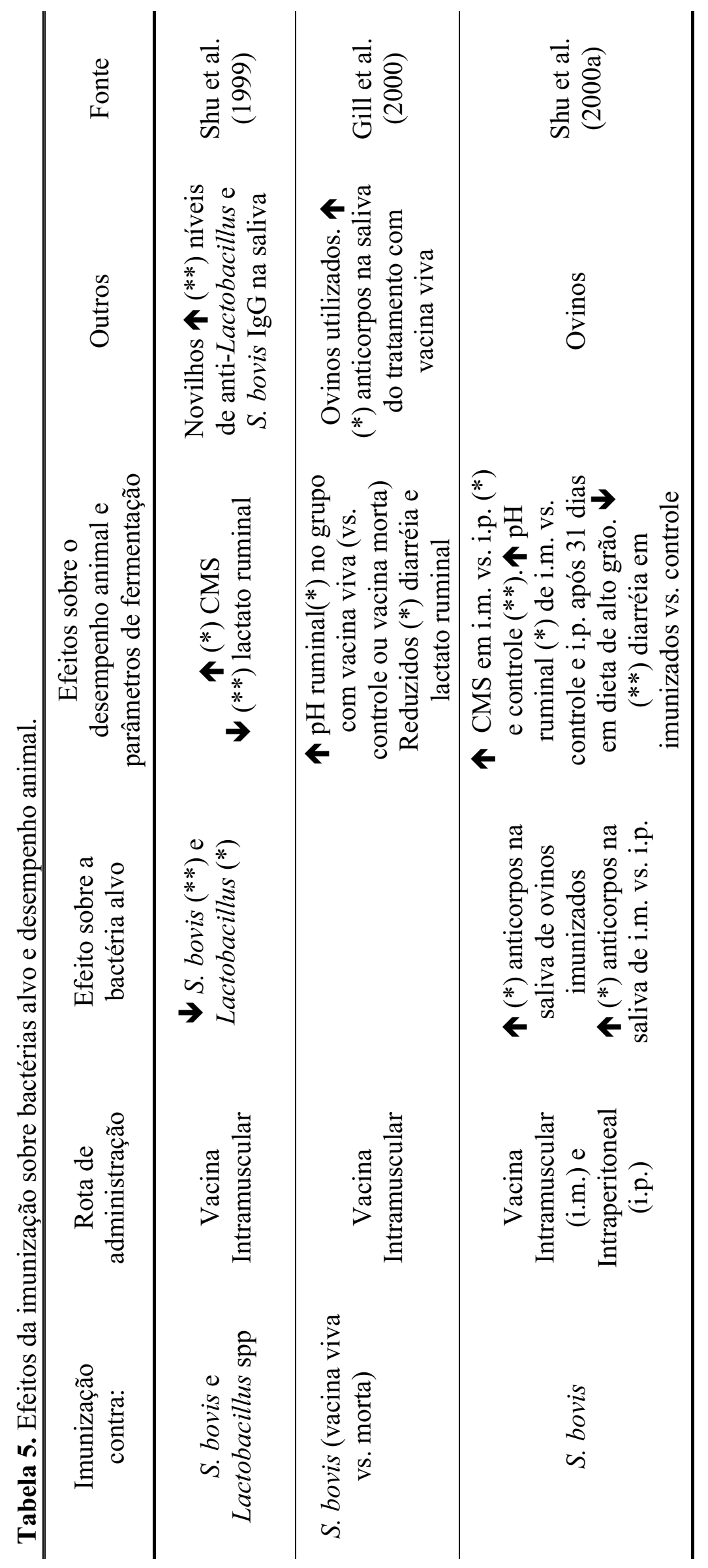




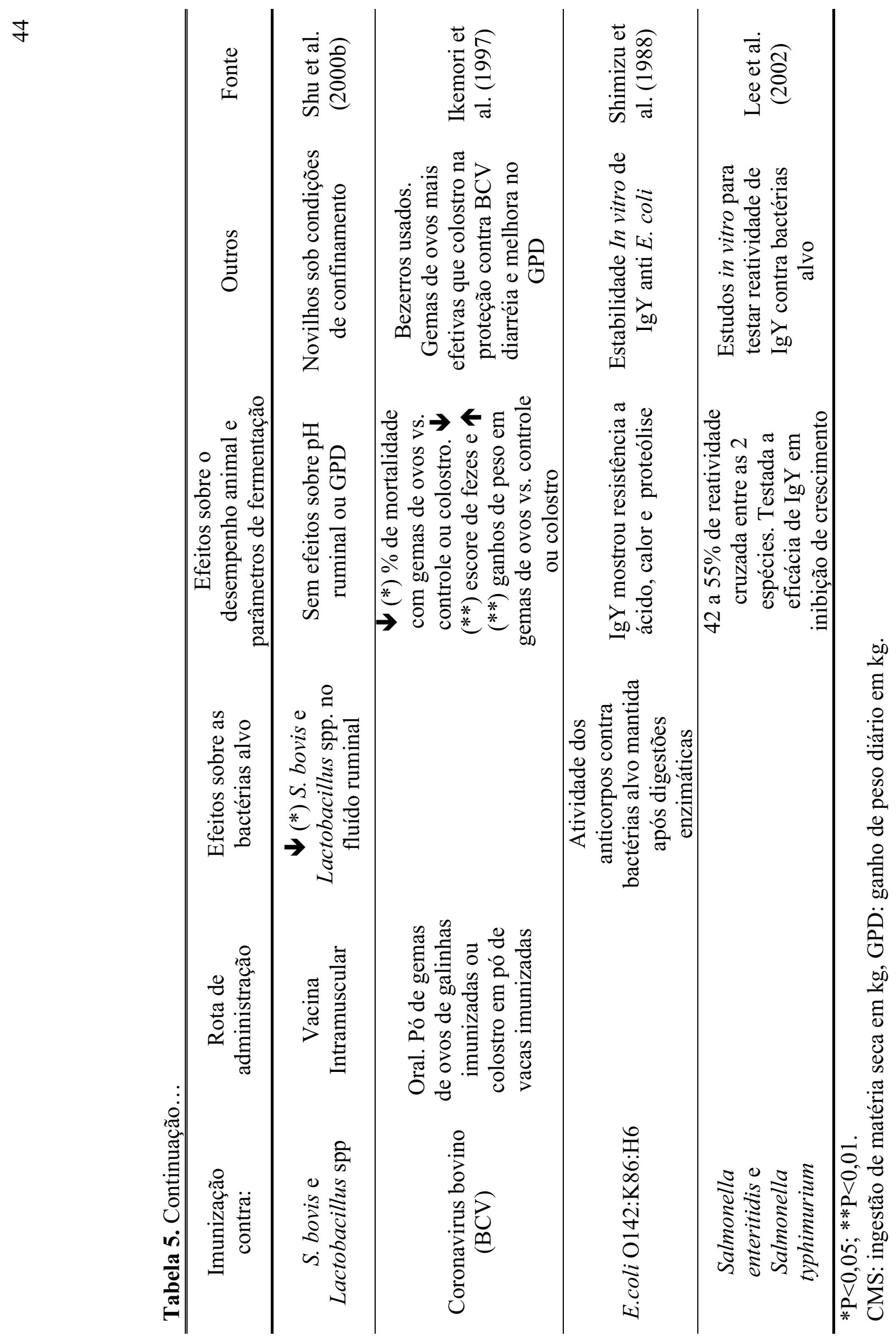




\section{CAPÍTULO 2}




\section{Suplementação de Anticorpos Policlonais ou Monensina Sódica sobre o} comportamento ingestivo e desempenho de bovinos Brangus e Nelores confinados.

RESUMO - Esse estudo foi realizado para avaliar o preparado de anticorpos policlonais (PAP) sobre o comportamento ingestivo (CING) e desempenho de bovinos Brangus (BR) e Nelore (NE) confinados. Foram utilizados 32 machos inteiros $(254,1 \pm 12,7 \mathrm{~kg})$, de cada um dos 2 grupos genéticos, e estes foram alimentados por 144 dias com dietas contendo ou monensina sódica (MON) ou PAP nas dosagens de 30 e $300 \mathrm{mg} / \mathrm{kg}$ de matéria seca (MS) respectivamente. Medidas no tempo foram coletadas de acordo com os períodos avaliados durante o estudo: adaptação, crescimento, terminação 1 e terminação 2. As observações foram feitas a cada 5 minutos durante $24 \mathrm{~h}$, aonde os dados das variáveis de CING foram coletados: tempos médios de ruminação (TR), de alimentação (TAL), de ócio, número de idas ao bebedouro, e número de refeições ao dia (REF/dia). As eficiências de alimentação (EAL) e ruminação (ERU) da MS e do FDN foram calculadas usando-se combinações dos dados de CING com os dados de consumo de MS e FDN. Não foi observado $(\mathrm{P}>0,05)$ efeito dos aditivos alimentares sobre as EAL e ERU da MS e do FDN. Houve efeito sobre REF/dia e TAL despendido por refeição (TALREF), onde animais suplementados com MON apresentaram maiores $(\mathrm{P}<0,05) \mathrm{REF} /$ dia, TR e animais recebendo PAP tiveram maior $(\mathrm{P}<0,05)$ TALREF. Animais recebendo PAP e MON apresentaram similares $(\mathrm{P}>0,05)$ GPD, CMS e CA. Os animais BR apresentaram maior $(\mathrm{P}<0,05)$ TALREF e CMS por refeição. Observouse $(\mathrm{P}<0,05)$ efeito dos grupos genéticos sobre EAL e ERU da MS e da FDN $(\mathrm{P}<0,01)$, onde bovinos BR apresentaram melhores eficiências quando comparados aos animais NE. Assim sendo, devido às similaridades nos resultados de CING, EAL, ERU e desempenho, PAP pode ser uma eventual alternativa à MON em dietas de alto teor de concentrado.

Palavras-chave: Ruminação, grupo genético, aditivos alimentares, confinamento. 


\title{
Effects of feeding Polyclonal Antibody Preparations or Sodium Monensin on feeding behavior and feedlot performance of Brangus and Nellore cattle
}

\begin{abstract}
This study was designed to test polyclonal antibody preparation (PAP) against several rumen microorganisms on feeding behavior and feedlot performance of Brangus (BR) and Nellore (NE) cattle. The experiment was designed as a $2 \times 2$ factorial arrangement of treatments using repeated measures over time, replicated 4 times (4 bullocks/pen), in which 32 9-mo-old bullocks $(254,1 \pm 12,7 \mathrm{~kg})$ of each of two breeds evaluated were fed for 144 days, diets containing either monensin (MON) or PAP at 30 or $300 \mathrm{mg} / \mathrm{kg}$ of dry matter (DM) daily; respectively. Measures over time were taken according to the periods evaluated during the study: adaptation, growing, finishing 1 and finishing 2. Visual appraisal was made every five minutes during $24 \mathrm{~h}$, and feeding behavior data was collected as follows: time spent eating (EAT), ruminating (RUM), resting, visits to water through and number of meals per day (MEA). Feed offerings and refusals were weighed daily. Feeding (FEEF) and rumination efficiencies (RUEF) of DM and NDF were calculated using combinations of feeding behavior data with DM and NDF intakes data. No significant $(\mathrm{P}>0,05)$ feed additives main effects were observed for FEEF and RUEF of DM and NDF, and for any of feeding behavior variables evaluated with the exception of RUM, MEA and EAT per meal (EATMEA); in which bullocks fed MON presented longer $(\mathrm{P}<0,05)$ RUM and greater $(\mathrm{P}<0,05)$ MEA and bullocks receiving PAP had longer $(\mathrm{P}<0,05)$ EATMEA. In addition, a similar feedlot performance was observed $(\mathrm{P}>0,05)$ between bullocks fed either MON or PAP. BR bullocks had longer $(\mathrm{P}<0,05)$ EATMEA and greater $(\mathrm{P}<0,05)$ DM intake per meal. Significant $(\mathrm{P}<0,05)$ breeds main effects were observed for all of FEEF and RUEF of DM and NDF, indicating that BR bullocks were more efficient than NE bullocks in all variables evaluated. In terms of feedlot performance, BR bullocks presented greater $(\mathrm{P}<0,05)$ average daily gain and $\mathrm{DM}$ intake, but similar feed conversion $(\mathrm{P}>0,05)$ when compared to NE bullocks. Thus, as bullocks fed either PAP or MON presented similar feeding behavior, FEEF, RUEF and feedlot performance, PAP present an alternative new technology to replace MON in feedlot diets.
\end{abstract}

Keywords: Rumination, breed types, feed additives, concentrate. 


\section{INTRODUÇÃO}

De acordo com um levantamento realizado por Millen et al. (2009), o Brasil confinou em 2008 cerca de 3.163 .750 animais, o que significa cerca de $547 \%$ a mais da produção animal que há 6 anos atrás. Aliado a isso, o país surge no ranking como o maior exportador de carne bovina do mundo, destinando apenas pra União Européia, cerca de 19,6\% das suas exportações de carne bovina (ABIEC, 2008).

Com o aumento do número de animais confinados, aumenta também a inclusão de grãos nas dietas, o que intensifica e aumenta o sistema de produção de carne bovina, mas também pode levar a distúrbios digestivos como a acidose. Sendo a acidose um dos principais fatores que levam ao uso de antibióticos na produção de ruminantes.

Em alguns lugares no mundo, particularmente na Europa, têm sido banido o uso dos ionóforos como promotores de crescimento, por estes serem classificados como antibióticos (OJEU, 2003), podendo contribuir com a emergência de microorganismos resistentes aos antibióticos (Newbold et al., 2001). Baseado nesses fatos, o mercado europeu importa toneladas de carne bovina do Brasil anualmente, e a busca por novas alternativas para substituir os ionóforos podem levar ao desenvolvimento de produtos alternativos que rendam a mesma eficiência e o mesmo custo-benefício que os ionóforos, porém sem restrições por parte de alguns mercados consumidores, como o europeu.

Os probióticos vêm sendo testados como alternativa para os ionóforos, mas os resultados relatados ainda são inconsistentes (DiLorenzo et al., 2006). Em alguns estudos, os probióticos melhoraram o desempenho e preveniram a acidose ruminal (Rust et al., 2000; Krehbiel et al., 2003), mas em outros os probióticos não tiveram efeito. (Ghorbani et al., 2002; Beauchemin et al., 2003; Elam et al., 2003).

Uma alternativa para os ionóforos que foi avaliado in vivo recentemente é a imunização (DiLorenzo et al., 2008; Blanch et al., 2009). Vacinação e doses orais de anticorpos policlonais contra baterias ruminais produtoras de lactato têm levado à redução da concentração de lactato no rúmen (Shu et al., 1999), aumento do pH ruminal (DiLorenzo et al., 2006) e maior consumo de matéria seca (Gill et al., 2000; Shu et al., 2000). Bovinos de genótipo Bos indicus predominam nos confinamentos do Brasil, e observações praticas e evidências científicas sugerem que esses animais possam ser 
mais susceptíveis a acidose que bovinos Bos taurus (Millen et al., 2009), é necessário suplementar aditivos que atuem na prevenção de quadros de acidose. O objetivo desse estudo foi avaliar os efeitos da suplementação de monensina sódica (MON) e do preparado de anticorpos policlonais (PAP) sobre o comportamento ingestivo e desempenho de bovinos Brangus (BR) e Nelore (NE) confinados com teores crescentes de concentrado.

\section{MATERIAL E MÉTODOS}

O trabalho foi conduzido de acordo com as normas do comitê de ética (CEEA) da Faculdade de Medicina Veterinária e Zootecnia, Universidade Estadual Paulista (UNESP), campus de Botucatu.

\section{Anticorpos Policlonais}

Os anticorpos policlonais foram produzidos pela CAMAS Inc., Le Center, MN. O produto comercial contém imunoglobulinas contra Streptococcus bovis (ATCC 9809), Fusobacterium necrophorum (ATCC 27852), Clostridium sticklandii (ATCC 12662), Clostridium aminophilum (ATCC 49906), Peptostreptococcus anaerobius (ATCC 49031), e Escherichia coli O157:H7 (ATCC 43895). Streptococcus bovis é a bactéria que mais produz ácido láctico, Fusobacterium necrophorum é o causador de abscessos hepáticos em animais com acidose, Clostridium sticklandii, Clostridium aminophilum, e Peptostreptococcus anaerobius são bactérias produtoras de amônia,e Escherichia coli O157:H7 é patogênica em humanos e também causadora de acidose.

\subsection{Animais e Local Experimental}

O estudo foi conduzido no confinamento experimental da UNESP, campus de Botucatu onde foram utilizados 64 animais machos, não castrados, com oito meses de idade, pertencentes a dois grupos genéticos (32 da raça Nelore e 32 da raça Brangus) e distribuídos aleatoriamente em 16 baias (4 animais/baia). O peso vivo médio inicial foi de $272,60 \pm 9,07$ e $236,63 \pm 15,37 \mathrm{~kg}$ para BR e NE, respectivamente.

\subsection{Manejo, Arraçoamento e Cuidados com os Animais}


Todos os animais foram submetidos ao mesmo fornecimento de dietas ad libitum, tipo de alojamento e manejo. As baias eram cobertas, protegendo os animais e o alimento do sol e da chuva e com boa facilidade na circulação do ar.

Antes do início do experimento os animais foram pesados, desverminados, vacinados contra doenças virais e bacterianas (rota e coronavírus, tétano, botulismo, e sete tipos Clostridium spp.; Pfizer Animal Health, New York, NY) e adaptados às baias e as dietas por período de 28 dias.

Os ingredientes das dietas foram adicionados no próprio vagão distribuidor, aonde foram também misturados. Os animais receberam as dietas ad libitum duas vezes ao dia: às $8 \mathrm{~h}(40 \%$ do total $)$ e $15 \mathrm{~h}(60 \%$ do total $)$, sempre com água constante nos bebedouros automáticos $\left(0,89 \mathrm{~m}^{2}\right)$. A ração foi fornecida em cada baia $\left(6,7 \mathrm{~m}^{2} /\right.$ animal $)$ em cocho de $5 \mathrm{~m}(1,25 \mathrm{~m} /$ animal). A quantidade de ração fornecida diariamente foi ajustada baseada na quantidade de sobras medidas antes do trato da manhã (8h), considerando-se 3\% como nível de sobras. A quantidade de ração fornecida e as sobras foram pesadas diariamente e amostradas semanalmente para análise bromatológica de matéria seca (MS), proteína bruta, extrato etéreo e matéria mineral, os quais foram avaliados segundo o AOAC (1997) e fibra detergente neutro (FDN) segundo Goering e Van Soest (1970). As concentrações de FDN (com $\alpha$-amilase estável sob calor e sulfito de sódio) e FDA foram determinadas usando-se um analisador de fibra (Modelo 200, Ankom Technology, Fairport, NY, EUA).

Os animais foram abatidos quando atingiram $5 \mathrm{~mm}$ de espessura de gordura subcutânea, mensurada por meio de ultrassonografia, para alcançar os requerimentos mínimos de gordura de cobertura do mercado brasileiro. A espessura de gordura subcutânea do músculo Longissimus dorsi foi mensurada via ultra-som a cada 28 dias, seguindo metodologia descrita por Perkins et al. (1992).

\subsection{Tratamentos e Dietas}

$\mathrm{O}$ estudo teve delineamento experimental inteiramente casualizado em arranjo fatorial $2 \times 2$, com quatro repetições por tratamento, nos quais 32 bovinos machos inteiros de cada grupo genético avaliado (BR ou NE) foram alimentados com dietas contendo MON (Rumensin, Elanco Animal Health, Indianapolis, IN, EUA) ou PAP 
(RMT Optimize, CAMAS Inc., Le Center, MN, EUA) fornecidos diariamente via suplemento com doses de 30 e $300 \mathrm{mg} / \mathrm{kg}$ de MS respectivamente.

Os animais passaram por quatro períodos durante o estudo: adaptação (ADAP), crescimento (CRES), e terminação 1 (TRM1) e 2 (TRM2). As dietas fornecidas nestes períodos continham 55, 70, 80 e $85 \%$ de concentrado, respectivamente, e foram compostas por silagem de grãos úmidos de milho, grãos de milho seco quebrados, polpa cítrica peletizada, farelo de soja, bagaço de cana cru, feno de Coast Cross e suplemento mineral e protéico (tabela 1). A dieta contendo 58\% de concentrado (ADAP) foi fornecida por período de 28 dias para adaptar os animais às dietas subsequentes. $\mathrm{O}$ critério para as mudanças de dieta foi baseado na espessura de gordura subcutânea mensurada por meio de ultrassonografia. Quando os animais atingiram média de $3 \mathrm{~mm}$ de gordura, estes foram passados de 70 (CRES) para 80\% (TRM1) de concentrado, e posteriormente quando atingiram $4 \mathrm{~mm}$ de gordura foram promovidos à dieta contendo $85 \%$ (TRM2) de concentrado. As dietas foram formuladas segundo o sistema Cornell Net Carbohydrate and Protein System 5.0.40 (CNCPS, 2000), cuja formulação está apresentada na tabela 1, esperando-se ganhos de peso diários (GPD) de 1,300 a 1,600 $\mathrm{kg} / \mathrm{dia} /$ animal. Os animais permaneceram no experimento durante 144 dias antes de serem abatidos: 28, 56, 30 e 30 dias nos períodos de ADAP, CRES, TRM1 e TRM2; respectivamente. Os animais foram pesados no início e no final de cada período, durante os quais os dados de desempenho e de comportamento foram coletados. Os animais passaram por jejum de sólidos de $16 \mathrm{~h}$ antes de cada pesagem.

A ingestão de matéria seca (CMS) foi medida para cada baia por meio da pesagem do alimento fornecido diariamente. A pesagem da sobra foi efetuada todos os dias antes do trato da manhã, fazendo-se, posteriormente, a média por animal. A conversão alimentar dos animais foi calculada dividindo-se o GPD pela CMS. O desempenho dos animais no presente estudo foi avaliado através do GPD, CMS (expressa em quilos e por porcentagem do peso vivo), e conversão alimentar.

\subsection{Comportamento Ingestivo}

Os animais foram submetidos à observação visual para avaliação do comportamento ingestivo, sendo observados a cada cinco minutos, durante quatro períodos de 24 horas. As observações foram realizadas sempre após 15 dias do início de 
um novo período (ADAP, CRES, TRM1 e TRM2). Durante as observações foram coletados dados para determinação do tempo despendido em ingestão, ruminação e ócio, expressos em minutos, conforme descrito por Johnson e Combs (1991), números de refeições (REF) e de visitas ao bebedouro. Como foi complicado mensurar o tempo que o animal leva ingerindo água, e essa atividade quase sempre ocorre em períodos menores que cinco minutos, decidiu-se então classificar como idas ao bebedouro a atividade de ingestão de água.

A observação visual foi feita por oito observadores treinados, em sistema de revezamento, sendo quatro observadores por vez, onde cada um observou quatro baias com quatro animais cada uma, ao todo foram observadas 16 baias, com quatro animais em cada baia, totalizando os 64 animais utilizados no experimento.

No dia de cada observação, dentro do respectivo período, foram feitas análises bromatológicas da dieta e das sobras para determinar a quantidade de matéria seca e FDN ingeridas pelos animais. Posteriormente, os dados de consumo de matéria seca e FDN no dia de cada observação, foram utilizados para cálculos das eficiências de alimentação e ruminação da matéria seca e do FDN de acordo com as seguintes equações, descritas por Carvalho et al. (2006):

1. $\mathrm{EALMS}=\mathrm{TAL} / \mathrm{CMS}$;

2. $\mathrm{EALFDN}=\mathrm{TAL} / \mathrm{CFDN}$;

Em que:

EALMS = Eficiência de alimentação da MS, expressa em minutos por quilo de MS consumida;

EALFDN $=$ Eficiência de alimentação do FDN, expressa em minutos por quilo de FDN consumido;

CMS = Consumo de MS no dia da observação, expressa em quilos;

CFDN = Consumo de FDN no dia da observação, expresso em quilos;

$\mathrm{TAL}=$ Tempo despendido em alimentação (ingestão), expresso em minutos.

3. $\mathrm{ERUMS}=\mathrm{TR} / \mathrm{CMS}$;

4. $\quad E R U F D N=T R / C F D N$; 
Em que:

ERUMS = Eficiência de ruminação da MS, expressa em minutos por quilo de MS ruminada;

ERUFDN = Eficiência de ruminação do FDN, expressa em minutos por quilo de FDN ruminado;

$\mathrm{TR}=$ Tempo despendido em ruminação, expresso em minutos.

\section{5. $\mathrm{TMT}=\mathrm{TAL}+\mathrm{TR}$}

Em que:

TMT = Tempo de mastigação total, expresso em minutos.

6. $\mathrm{TALREF}=\mathrm{TAL} / \mathrm{REF}$;

7. $\mathrm{CMSREF}=\mathrm{CMS} / \mathrm{REF}$;

Em que:

TALREF = Tempo de alimentação despendido em cada refeição, expresso em minutos; $\mathrm{REF}=$ Número de refeições por dia;

CMSREF $=$ Consumo de MS por refeição, expresso em quilos.

As EALMS, EALFDN, ERUMS e ERUFDN, também foram expressos em gramas de MS por minuto.

\subsection{Delineamento Experimental e Análise Estatística}

O delineamento experimental foi inteiramente casualizado em arranjo fatorial 2 $\times 2$ em medidas repetidas no tempo, onde a influência de dois grupos genéticos (BR e $\mathrm{NE}$ ), e de dois aditivos alimentares (PAP e MON) sobre o comportamento ingestivo e o desempenho foram avaliados em quatro períodos de mensurações (ADAP, CRES, TRM1, TRM2)

Com relação ao modelo estatístico experimental, as baias foram consideradas as unidades experimentais, e as características de comportamento ingestivo e desempenho dos animais, foram analisadas utilizando-se o PROC MIXED do SAS (2003) de acordo 
com o modelo abaixo e teste de Tukey para comparação entre médias. Testes de normalidade e de heterogeneidade de variâncias foram realizados antes de se proceder a análise de variância propriamente dita, e quando necessário os dados foram transformados. Resultados foram considerados significantes a $\mathrm{P}<0,05$.

$Y_{i j k l}=\mu+G R_{i}+T_{j}+G R * T_{i j}+\gamma_{i j l}+P_{k}+G R * P_{i k}+T^{*} P_{j k}+G R * T^{*} P_{i j k}+e_{i j k l}$

em que:

- $Y_{\mathrm{ijkl}}$ é a observação na $1^{\text {ésima }}$ baia, no jésimo tratamento, no $\mathrm{i}^{\text {ésimo }}$ grupo racial e $\mathrm{k}^{\text {ésimo }}$ período de mensuração;

- $\mu$ é a média geral;

- $\mathrm{GR}_{\mathrm{i}}$ é o efeito do $\mathrm{i}^{\text {ésimo }}$ grupo racial, sendo $\mathrm{i}=1$ : NE e 2: BR;

- $\mathrm{T}_{\mathrm{j}}$ é o efeito do $\mathrm{j}^{\text {ésimo }}$ aditivo alimentar, sendo $\mathrm{j}=1$ : MON e 2: PAP;

- GR* $\mathrm{T}_{\mathrm{ij}}$ é a interação entre o $\mathrm{i}^{\text {ésimo }}$ grupo racial e o jésimo aditivo alimentar;

- $\gamma_{\mathrm{ijl}}$ é o erro experimental "a" associado a observação $\mathrm{Y}_{\mathrm{ijl}}\left(0 ; \sigma_{\gamma}^{2}\right)$;

- $\mathrm{P}_{\mathrm{k}}$ é o efeito do $\mathrm{k}^{\text {ésimo }}$ período, sendo $\mathrm{k}=1$ : ADAP; 2: CRES; 3: TRM1 e 4:TRM2;

- GR* $\mathrm{P}_{\mathrm{ik}}$ é a interação entre o $\mathrm{i}^{\text {ésimo }}$ grupo racial e o $\mathrm{k}^{\text {ésimo }}$ período;

- $\mathrm{T}^{*} \mathrm{P}_{\mathrm{jk}}$ é a interação entre o $\mathrm{j}^{\text {ésimo }}$ aditivo alimentar e o $\mathrm{k}^{\text {ésimo }}$ período;

- GR*T* $\mathrm{P}_{\mathrm{ijk}}$ é a interação entre o $\mathrm{i}^{\text {śimo }}$ grupo racial, o jésimo aditivo alimentar e o $\mathrm{k}^{\text {ésimo }}$ período;

- $\mathrm{e}_{\mathrm{ijkl}}$ é o erro experimental “b” associado a observação $\mathrm{Y}_{\mathrm{ijkl}}\left(0 ; \sigma_{e}^{2}\right)$.

\section{RESULTADOS}

\subsection{Variáveis do Comportamento Ingestivo}

Não foi observado $(\mathrm{P}>0,05)$ efeito principal dos aditivos alimentares sobre as variáveis do comportamento ingestivo as quais (Tabela 2), houve diferença para número de refeições por dia (REF/dia) e tempo de alimentação despendido por refeição (TALREF). Animais suplementados com MON apresentaram maior $(\mathrm{P}<0,05)$ $\mathrm{REF} /$ dia que animais recebendo PAP. No entanto, bovinos suplementados com PAP tiveram maior $(\mathrm{P}<0,01)$ TALREF que àqueles que receberam MON. Foi encontrada interação $(\mathrm{P}<0,05)$ entre aditivo alimentar e período para TR (Figura 1), no qual animais recebendo MON apresentaram maior TR que animais recebendo PAP nos 
períodos de TRM1 e TRM2, mas não houve diferença entre animais suplementados com MON e PAP nos períodos de ADAP e CRES.

Não foi observado $(\mathrm{P}>0,05)$ efeito principal dos grupos genéticos sobre o comportamento ingestivo (Tabela 2), com exceção do consumo médio de matéria seca por refeição (CMSREF), onde animais BR apresentaram maior $(\mathrm{P}<0,05)$ CMSREF quando comparados aos bovinos NE. Aliado a isso, foram encontradas interações $(\mathrm{P}<$ 0,05) entre grupos genéticos e períodos para idas ao bebedouro (Figura 2) e TALREF (Figura 3). Animais BR apresentaram maior TALREF no período de ADAP, entretanto nenhuma diferença foi detectada entre os grupos genéticos nos demais períodos. Bovinos NE foram mais ao bebedouro que animais BR nos períodos de ADAP e CRES, e não foi observada diferença entre BR e NE no período de TRM1; no entanto animais BR visitaram mais o bebedouro que os animais NE no período TRM2.

Foi observado $(\mathrm{P}<0,01)$ efeito principal dos períodos sobre as variáveis do comportamento ingestivo: TO, TAL, TMT, REF/DIA e CMSREF (Tabela 2). Bovinos confinados tiveram maior TO nos períodos TRM1 e TRM2 quando comparados ao período de CRES, onde por sua vez estes apresentaram maior TO que no período de ADAP. Com relação ao TAL o tempo despendido diminuiu linearmente do período de ADAP para o de TRM2. Os animais apresentaram menor TMT nos períodos TRM1 e TRM2 que no período de CRES, no qual foi observado menor TMT quando comparado ao período de ADAP. Em termos de REF/DIA, houve maior freqüência no período TRM1 em relação aos demais períodos, os quais não mostraram diferenças entre eles. No entanto, o CMSREF foi menor no período de ADAP quando comparados aos demais períodos, os quais não diferiram entre si.

\subsection{Eficiências de Alimentação e Ruminação da MS e do FDN}

Não foi observado $(\mathrm{P}>0,05)$ efeito principal dos aditivos alimentares sobre as eficiências de alimentação e ruminação tanto da MS quanto do FDN avaliadas neste estudo (Tabela 3). No entanto, observou-se efeito $(\mathrm{P}<0,05)$ principal dos grupos genéticos sobre as seguintes variáveis: eficiência de alimentação da MS (EALMS), eficiência de ruminação da matéria seca (ERUMS) e eficiência de ruminação do FDN (ERUFDN) (Tabela 3); Os animais BR foram mais eficientes em todos esses parâmetros quando comparados aos animais NE. Ainda foram encontradas interações (P 
$<0,05)$ entre grupos genéticos e períodos para consumo da MS (CMSDIA) e ingestão de FDN (CFDN) no dia das observações (Figuras 4 e 5; respectivamente), onde animais BR tiveram maior CFDN que os animais NE em todos períodos avaliados e ainda apresentaram maior CMSDIA nos períodos de CRES, TRM1 e TRM2. Essas diferenças entre bovinos BR e NE se acentuaram ainda mais, no que diz respeito ao CFDN e CMSDIA, nos períodos de TRM1 e TRM2. Da mesma forma, foi observado interações entre grupos genéticos e períodos para EALFDN (expresso em min/kg de MS; Figura 6), EALMS (expresso em g de MS/min; Figura 7), EALFDN (expressos em g de FDN/min; Figura 8), e ERUMS (expressos em g de MS/min; Figura 9), onde animais BR apresentaram valores maiores $(\mathrm{P}<0,05)$ que bovinos NE nos períodos de TRM1 e TRM2, não sendo observadas diferenças significativas entre os grupos genéticos nos períodos de ADAP e CRES.

Foi encontrado efeito $(\mathrm{P}<0,01)$ principal dos períodos para as variáveis EALMS (min/kg de MS), ERUMS (min/kg de MS), ERUFDN (min/kg de FDN) e ERUFDN (g de FDN/min; Tabela 2). Bovinos confinados foram mais eficientes em termos de EALMS nos períodos TRM1 e TRM2 em relação aos períodos de CRES a ADAP, no qual apresentaram a menor eficiência. Já em termos de ERUMS, do período onde os animais foram mais eficientes para o período em que estes foram menos eficientes, foi encontrado: TRM1 > TRM2 > CRES > ADAP. Para a ERUFDN, expressa tanto em min/kg de FDN quanto em g de FDN/min, foi observada significante melhora na eficiência dos animais do período de ADAP para o de TRM1, no entanto, no período TRM2 os animais foram menos eficientes que no TRM1 e apresentaram similar eficiência quando comparados aos períodos de ADAP e CRES.

\subsection{Desempenho}

Não foi observado $(\mathrm{P}>0,05)$ efeito principal dos aditivos alimentares para as variáveis de desempenho estudadas (Tabela 4). No entanto foi encontrada interação entre aditivos alimentares e período para CMS em \% do peso vivo (Figura 12), onde animais suplementados com $\mathrm{PAP}$ tiveram maior $(\mathrm{P}<0,05) \mathrm{CMS}$ que àqueles suplementados com MON nos períodos de CRES e TRM1, não havendo diferença entre os aditivos testados nos períodos de ADAP e TRM2. Foi observada interação $(\mathrm{P}<0,05)$ entre grupos genéticos e aditivos alimentares para CMS em \% do peso vivo (Figura 11), 
onde animais BR suplementados com PAP apresentaram maior $(\mathrm{P}<0,05) \mathrm{CMS}$ que os animais NE suplementados com PAP, no entanto, não foi encontrada diferença significativa quando animais BR e NE foram suplementados com MON. Da mesma forma, não foram observadas diferenças entre animais NE suplementados com MON e PAP, e entre bovinos BR recebendo MON e PAP.

Foi encontrado efeito $(\mathrm{P}<0,05)$ principal dos grupos genéticos sobre o desempenho dos animais confinados (Tabela 4), onde bovinos BR apresentaram maior GPD em relação aos animais NE, porém não foi observada $(\mathrm{P}>0,05)$ diferença entre os grupos genéticos para a conversão alimentar. Foram observadas também interações $(\mathrm{P}<$ 0,05) entre grupos genéticos e períodos para CMS expressa tanto em quilos (Figura 10) como em \% do peso vivo (Figura 13) os animais BR apresentaram maior $(\mathrm{P}<0,05)$ CMS em quilos que bovinos $\mathrm{NE}$ em todos os períodos de avaliação com exceção da ADAP. Já para CMS em \% do peso vivo, animais BR apresentaram maior CMS que bovinos NE nos períodos TRM1 e TRM2, não sendo detectada diferenças nos períodos de ADAP e CRES.

Com respeito aos períodos foi observado efeito $(\mathrm{P}<0,01)$ principal sobre o GPD e a conversão alimentar. (Tabela 4). Houve menor GPD no período de ADAP em relação aos demais períodos, que não diferiram entre si. Por outro lado, melhor conversão alimentar foi observada no período de ADAP e CRES quando comparados aos períodos de TRM1 e TRM2.

\section{DISCUSSÃO}

\subsection{Aditivos Alimentares}

Com relação às variáveis do comportamento ingestivo, animais suplementados com MON apresentaram maior REF/dia e menor TALREF que animais recebendo PAP, indicando que como o CMSREF era numericamente menor, animais suplementados com MON foram mais vezes ao cocho, aumentando com isso a taxa de passagem da digesta do rúmen para o omaso, e consequentemente aumentando o TR desses animais, o qual foi observado apenas nos períodos de TRM1 e TRM2 (Figura 1), nos quais em teoria os animais apresentariam menor tamponamento do rúmen devido ao reduzido teor de FDN. O menor TALREF e o maior REF/dia em bovinos recebendo MON, 
provavelmente devem estar ligados a reduzida variação no CMS. Burrin et al. (1988) e Stock et al. (1995) reportaram reduzida variação no CMS quando MON foi fornecida a bovinos confinados. Galyean et al. (1992) observaram que a reduzida variação de CMS melhorou o desempenho de bovinos mantidos em confinamento, no entanto, no presente estudo e no estudo de Stock et al. (1995) nenhuma melhora em desempenho foi encontrada quando bovinos foram suplementados com MON. Em relação às demais variáveis do comportamento ingestivo, animais suplementados com MON e PAP apresentaram o mesmo padrão de comportamento.

Com respeito às eficiências de alimentação e ruminação da MS e do FDN, os animais suplementados com PAP mostraram eficiências similares àqueles suplementados com MON, apesar das diferenças encontradas nas variáveis de comportamento ingestivo, indicando haver alguma semelhança em relação aos efeitos que PAP e MON causam em bovinos confinados. Ainda não estão claras as razões pelas quais a suplementação de PAP proporcionou eficiências similares ao do fornecimento de $\mathrm{MON}$, no entanto os valores referentes às eficiências obtidos neste estudo são maiores que valores encontrados por outros autores (Rotger et al., 2006; Robles et al., 2007) aonde bovinos de corte também foram alimentados com dietas de alto concentrado com similares níveis de energia, indicando que os aditivos alimentares testados neste estudo podem de alguma forma melhorar a eficiência de alimentação e ruminação da MS e do FDN de bovinos confinados de alguma forma. Aliado a isso, animais suplementados com PAP apresentaram similar desempenho que àqueles suplementados com MON e ainda mostraram maior CMS nos períodos de CRES e TRM1, concordando com os dados obtidos por Millen et al. (2007) que conduziram estudo similar a este e encontraram desempenho semelhante entre animais recebendo PAP e MON, relatando ainda a menor incidência de lesões ruminais e o maior CMS quando PAP foi fornecido como possíveis causas para aquele desempenho equivalente. Melhora no CMS em animais alimentados com dietas de alto concentrado e recebendo PAP têm sido reportado por alguns autores (Shu et al., 1999; Gill et al., 2000, Shu et al., 2000; Dahlen et al., 2003), os quais compararam PAP apenas a um tratamento controle negativo (sem aditivo alimentar). Por outro lado, diversos autores (Raun et al., 1976; Burrin et al., 1988; Fox et al., 1988; Chirase et al., 1991; Galyean et al., 1992) observaram redução do CMS quando MON foi adicionada à dieta. Barducci et al. 
(2009) não encontraram diferenças no CMS quando bovinos Brangus confinados foram alimentados com PAP e/ou MON.

Se o aumento do CMS nos bovinos confinados, for pela inclusão de PAP na dieta, poderia ser devido à fermentação mais saudável, o que leva a menor produção de ácido lático e consequentemente melhor ambiente ruminal para ação dos microorganismos, podendo melhorar assim a digestibilidade dos nutrientes como mostrado na Tabela 4, onde animais que receberam PAP apresentaram numericamente melhor conversão alimentar que bovinos que receberam MON, apesar de não significativo estatisticamente $(\mathrm{P}<0,18)$. Em contrapartida, a MON pode diminuir a CMS em bovinos alimentados com dietas de alto concentrado devido a alguns dos seus efeitos no rúmen: redução da proteólise (Dinius et al., 1976; Thornton e Owens, 1981; Hanson e Klopfenstein, 1979), diminuição da digestão de fibra (Cottyn et al., 1983), e aumento da concentração de propionato (Richardson et al., 1976; Prange et al., 1978; Rogers e Davis, 1982; Allen, 2000). No presente estudo, no entanto, a MON não melhorou a conversão alimentar como relatado em estudos anteriores (Burrin et al., 1988, Barducci et al., 2009).

\subsection{Grupos Genéticos}

Com relação às variáveis do comportamento ingestivo, animais BR tiveram maior CMSREF que animais NE, e consequentemente apresentaram maiores TALREF (período de ADAP), CMSDIA e CFDN (períodos de CRES, TRM1 e TRM2), refletindo assim o que ocorreu nos parâmetros de desempenho, no qual bovinos BR apresentaram maior CMS, em quilos e em \% do peso vivo, que bovinos NE, principalmente nos períodos de TRM1 e TRM2 onde dietas contendo maiores teores de energia foram fornecidas. O menor CMSREF por animais NE pode estar ligado aos quimiorreceptores na parede ruminal, que de acordo com Cunningham (1999) controlam o CMS à medida que acúmulos de ácidos tornam-se pronunciado dentro do rúmen, prejudicando a digestão do alimento ali presente. Já Van Soest (1994) relatou que a inibição da CMS devido ao acúmulo de ácidos no rúmen é em função da incidência de lesões ruminais, como as rumenites, o que diminui a superfície de absorção de ácidos graxos de cadeia curta no rúmen, liderando a queda mais acentuada do $\mathrm{pH}$. Millen et al. (2007) 
observaram que animais NE apresentaram maior incidência de rumenites e menor CMS que animais cruzados em estudo semelhante a este.

Observou-se ainda número maior de idas ao bebedouro para os animais NE nos períodos de ADAP e CRES quando comparados aos animais $\mathrm{BR}$, que poderia ser explicado pelo fato de animais NE serem mais susceptíveis à acidificação ruminal quando alimentados com dietas de altos teores de concentrado (Millen et al., 2009), o que levaria à maiores ingestões de água, principalmente quando estes estão se adaptando à dietas com altos teores de concentrado, pois mesmo no período de CRES a observação foi realizada apenas 15 dias após a introdução da novo dieta. Todavia no período de TRM2, bovinos NE mostraram número menor de idas ao bebedouro quando comparados aos animais BR, o que poderia ser explicado pelo menor CMS, em \% do peso vivo desses animais no período TRM2 quando comparados aos períodos ADAP, CRES e TRM1, fazendo com que a fermentação seja menos intensa e os animais necessitem ingerir menor quantidade de água. Bovinos BR, no entanto, não apresentaram diferenças em termos de idas ao bebedouro através dos períodos, o que poderia indicar melhor adaptação as dietas com altos teores de concentrado que bovinos NE. Em relação às demais variáveis do comportamento ingestivo, não foi observada diferença entre os grupos genéticos testados.

Com relação às eficiências de alimentação e ruminação da MS e do FDN, animais BR apresentaram melhores eficiências que bovinos NE em todas as variáveis analisadas, indicando que bovinos BR foram mais eficientes que bovinos NE quando alimentados com dietas de alto teor de concentrado, principalmente nos períodos de TRM1 e TRM2, onde dietas contendo maiores teores de energia foram fornecidas, o que foi observando nas interações obtidas para EALFDN, EALMS e ERUMS. Uma possível causa desta melhor eficiência é que no presente estudo não houve diferença entre os grupos genéticos estudados nas variáveis de TR, TO, TAL, TMT e REF/dia, o que indica que animais BR foram mais eficientes devido ao maior CMS em um mesmo intervalo de tempo quando comparados a bovinos NE. Esses dados estão de acordo com os relatados por Sarti et al. (2007) que estudaram bovinos confinados com diferentes graus de sangue Zebu e relataram que à medida que o nível de concentrado na dieta aumentou e o teor de FDN diminuiu, animais com maior proporção de sangue europeu se mostram mais eficientes tanto na ruminação da MS quanto do FDN que animais NE 
puros. Alguns autores como Millen et al. (2009) relataram que talvez a maior susceptibilidade de animais Zebu à acidificação ruminal poderia causar redução na eficiência destes animais quando estes recebem dietas com altos teores de concentrado. No entanto, ainda não está claro o mecanismo que leva bovinos NE apresentarem piores eficiências e consequentemente reduzido desempenho comparados a animais cruzados quando dietas altamente energéticas são fornecidas, necessitando assim mais estudos para se averiguar quais as razões desta reduzida eficiência.

No tocante ao desempenho, o maior GPD e CMS observados para animais com maior proporção de sangue taurino em relação aos zebuínos puros (BR e NE, respectivamente no presente estudo) têm sido relatado por diversos autores (Frisch e Vercoe, 1969; Rogerson et al.,1968; Ledger et al., 1970; Fox et al., 1988; Cruz et al., 1995; Sherbeck et al., 1996; Krehbiel et al., 2000; Leme et al., 2000; Cucki, 2006; Ferrel et al., 2006; Millen et al., 2007). Entretanto, como não foi encontrada diferença entre os grupos genéticos para a conversão alimentar, o maior GPD em animais BR poderia ser atribuído em grande parte, ao maior CMS, o qual também foi determinante para a melhor eficiência de alimentação e ruminação da MS e do FDN em animais BR como discutido anteriormente. Ainda, comparando-se animais BR e NE suplementados com PAP, foi observado maior CMS em \% do peso vivo para bovinos da raça BR, entretanto, não foi encontrado diferença quando se comparou bovinos $\mathrm{BR}$ e $\mathrm{NE}$ suplementados com MON. Como já discutido anteriormente o fornecimento de MON reduz o CMS em bovinos confinados (Burrin et al., 1988; Fox et al., 1988; Chirase et al., 1991), porém neste estudo, a suplementação pode ter reduzido o CMS de animais BR a certo ponto, que este passou a ser similar ao de animais NE, já que animais BR apresentaram maior CMS que bovinos NE considerando-se todo o período experimental, e maiores CMS são esperados para bovinos cruzados quando comparados com animais Zebu puros (Ledger et al., 1970; Fox et al., 1988; Millen, 2008). Assim sendo, devido a similares conversões alimentares encontradas para BR e NE, o melhor desempenho de bovinos cruzados parece estar ligado ao maior CMS, como já relatado em estudo de Millen (2008).

\subsection{Períodos}


Em relação aos períodos, os TAL e TMT diminuíram com a inclusão de concentrado na dieta. De acordo com Mertens (1996), o conteúdo de fibra é inversamente relacionado ao conteúdo de energia líquida e, ao se elevar o nível de FDN da dieta, ocorre um aumento no tempo gasto para ingestão, de modo que o animal possa suprir suas exigências energéticas. No presente estudo, com a diminuição dos teores de fibra e aumento na porcentagem de energia das dietas até atingir $85 \%$ de concentrado, provavelmente os animais atingiram a saciedade mais rapidamente, o que poderia ser reflexo da maior produção e absorção de ácidos graxos de cadeia curta no rúmen, provocando diminuição no TAL e TMT dos animais e aumentando com isso o TO. Bürger et al. (2000) utilizando dietas com 30, 45, 60, 75 e 90\% de concentrado, encontraram diminuição linear nos tempos de ingestão, à medida que os níveis de concentrado da dieta aumentavam. Menores valores de TMT foram observados nas dietas de $80 \%$ e $85 \%$ de concentrado em relação às dietas com maior quantidade de fibra, concordando com Mertens (1997) que relatou que em dietas com maior quantidade de fibra, há estímulo da atividade mastigatória e redução da produção de ácidos. Ainda, menor TMT pode ser explicado pelo fato de que, nas dietas com maiores proporções de concentrado, o tamanho de partícula é menor em relação a dietas com maiores teores de fibra, e este fator, juntamente com maior eficiência na redução do tamanho das partículas, também influencia na diminuição do TMT (Deswysen et al., 1987).

Em relação ao TO, este aumentou o que já era esperado, pelo fato dessa variável ser diretamente relacionada com os TMT e TAL; já que à medida que as quantidades de concentrado foram aumentando, os TAL, TMT e consequentemente o TR diminuíram, restando mais tempo para o animal permanecer em ócio. Segundo Costa et al. (1983), o comportamento de ócio é considerado como sendo o período em que os animais não estão comendo, ruminando ou ingerindo água. Neste estudo, os animais passaram maior parte do tempo em ócio em relação aos tempos de ingestão e ruminação, principalmente nos períodos de TRM1 e TRM2, onde os níveis de concentrado foram maiores.

Em relação ao REF/dia e o CMSREF houve variação entre os períodos, onde da ADAP para o CRES o REF/dia não mudou, porém o CMSREF aumentou, o que pode ser explicado pela diminuição no teor de fibra e conseqüente melhora da qualidade da dieta do período de CRES. Já do período de CRES para o de TRM1 o REF/dia 
aumentou e o CMSREF não se alterou, o que pode estar ligado também à melhora da qualidade da dieta, e à maior exigência dos animais nesse período, já que a deposição de gordura já havia se iniciado, o que pode ser visto na figura 13 , onde o CMS em \% do PV foi maior principalmente nesses períodos de CRES e TRM1. Do período de TRM1 para o de TRM2 o CMSREF não se alterou, porém o REF/dia diminuiu, o que pode estar ligado a regulação pelos quimiorreceptores da parede do rúmen como descrito por Cunningham (1999). Para Mertens (1992) o CMS é regulado não só pela seleção, mas por vários fatores referentes ao animal e ao alimento (quantidade de fibra, demanda energética, taxa metabólica, etc); sendo que o maior teor de energia no período de TRM2 poderia estar influenciando a redução do CMS devido ao acúmulo de ácidos orgânicos no rúmen, consequentemente proporcionando maior acidificação ruminal.

No tocante às eficiências, os animais foram mais eficientes no período de TRM1, onde os animais receberam dieta com $80 \%$ de concentrado, concordando com Dulphy et al. (1980), que reforçaram a afirmativa de que, elevando-se a inclusão de concentrado na dieta, desde que não ocorram problemas relacionados a redução do CMS, ocorre aumento da eficiência de alimentação e ruminação. O fato que pode ter contribuído para tal resultado seria o maior CMS e o segundo menor TAL neste período (maior apenas que o do período de TRM2), já que o TAL é inversamente correlacionado com a eficiência de alimentação. Parece que a dieta de $85 \%$ de concentrado fornecida no período de TRM2 reduziu a degradabilidade da fibra no rúmen, pois as eficiências de alimentação e ruminação do FDN foram semelhantes ao período de CRES, onde dieta com $70 \%$ de concentrado foi oferecida. Assim sendo, pode ter ocorrido maior acidificação ruminal no período de TRM2 devido ao maior teor de energia da dieta, como relatado por Owens et al. (1998).

Com respeito ao desempenho, os animais apresentaram maior GPD nos períodos de CRES, TRM1 e TRM2 em relação a ADAP pois neste período os animais estavam se adaptando às dietas, e esta ainda continha menos energia que as dietas dos períodos subseqüentes. Estes achados discordam de Owens et al. (1993) que relataram maior proporção de gordura no ganho diário à medida que os animais avançaram nos dias de confinamento, pois a deposição de gordura despende mais energia comparada com a deposição de proteína, levando a uma diminuição no GPD. Em relação a CA, esta piorou à medida em que o nível de concentrado foi aumentando, o que está de acordo 
estudos anteriores (Gonçalves et al., 1991, Euclides Filho et al., 1997, Ferreira, 1997 e Gesualdi Júnior et al., 2000), onde devido ao acúmulo de gordura na carcaça e o conseqüente aumento dos requerimentos de energia metabolizável para mantença.

\section{CONCLUSÃO}

Animais da raça Brangus foram mais eficientes que bovinos Nelore em termos de alimentação e ruminação da MS e do FDN, principalmente quando alimentados com teores de concentrado iguais ou maiores que $80 \%$.

Com relação aos aditivos alimentares, a MON reduziu o TALREF e aumentou o $\mathrm{REF} / \mathrm{dia}$, o que pode ter colaborado com o reduzido CMS em \% do peso vivo promovida pela MON. Assim sendo, devido às similaridades nos resultados de: comportamento ingestivo, eficiências de alimentação e ruminação da MS e do FDN, e desempenho em confinamento, PAP pode ser uma eventual alternativa a MON quando dietas de alto teor de concentrado são fornecidas a bovinos confinados, tanto pelos seus efeitos quanto pela resistência de alguns mercados ao uso de ionóforos antibióticos na produção de bovinos de corte.

\section{REFERÊNCIAS BIBLIOGRÁFICAS}

ALLEN, M. S. Effects of diet on short-term regulation of feed intake by lactating dairy cattle. J. Dairy Sci, v.83, p.1598, 2000.

AOAC. Official Methods of Analysis. $16^{\text {th }}$ ed. Assoc. Off. Anal. Chem., Arlington, VA, 1997.

BARDUCCI, R. S.; SARTI, L. M. N.; ARRIGONI, M. D. B. et al. Feedlot performance of Brangus cattle fed monensin or polyclonal antibody preparation against lactateproducing rumen bacteria. J. Anim. Sci, v.87, E-suppl.2, p.283-284, 2009.

BEAUCHEMIN, K. A.; YANG, W. Z; MORGAVI, D. P. et al. Effects of bacterial direct-fed microbials and yeast on site and extent of digestion, blood chemistry, and subclinical ruminal acidosis in feedlot cattle. J. Anim. Sci, v.81, p.16281640, 2003. 
BLANCH, M.; CALSAMIGLIA, S.; DILORENZO, N. et al. Physiological changes in rumen fermentation during acidosis induction and its control using a multivalent polyclonal antibody preparation in heifers. J. Anim. Sci, v.87, p.1722-1730, 2009.

BÜRGER, P.J.; PEREIRA, J.C.; QUEIROZ, A.C. et al. Comportamento ingestivo em bezerros holandeses alimentados com dietas contendo diferentes níveis de concentrado. Revista Brasileira de Zootecnia, v.29, p.236-242, 2000.

BURRIN, D. G.; STOCK, R. A.; BRITTON, R. A. Monensin level during grain adaptation and finishingp erformance in cattle. J. Anim. Sci, v.66, p.513-521, 1988.

CARVALHO, S.; RODRIGO, M. T.; BRANCO, R. H. et al. Comportamento ingestivo de cabras Alpinas em lactação alimentadas com dietas contendo diferentes níveis de fibra em detergente neutro proveniente da forragem. Revista Brasileira de Zootecnia, v.35, n.2, p.562-568, 2006.

CHIRASE, N. K.; HUTCHENSON, D. P.; THOMPSON, G. B. Feeding behavior of steers and heifers fed a high concentrate diet with or without monensin. J. Anim. Sci, v.69, Suppl.1, p.61, 1991.

CNCPS - Cornell Net Carbohydrate and Protein System. The net carbohydrate and protein system for evaluating herd nutrition and nutrients excretion. Version 5.0. Ithaca, NY. p.37, 2000.

COSTA, M.J.R.P.; J.C. MESQUITA; A.A. JUNQUEIRA FILHO. 1983. Comportamento de vacas Holandesas em pastagem. In: Encontro Paulista de Etologia,1, Jaboticabal, 1983. Anais... Jaboticabal: UNESP/FCAVJ, p.251.

COTTYN, B. G.; FIEMS, L. O.; BOUCQUE, G. V. et al. Effect of monensin-sodium and avoparcin on digestibility and rumen fermentation. $\mathbf{Z}$ Tierphysiol Tiernahr Futtermittelkd, v.49, p.227-286, 1983.

CRUZ, G. M.; TULLIO, R. R.; ESTEVES, S. N. et al. Peso ótimo de abate de machos cruzados para produção do bovino jovem. I - Desempenho em confinamento e características de carcaça. In: REUNIÃO ANUAL DA SOCIEDADE BRASILEIRA DE ZOOTECNIA, 32., 1995, Brasília. Anais... Viçosa: Sociedade Brasileira de Zootecnia, p.223, 1995. 
CUCKI, T. O. A eficiência do sistema superprecoce com bovinos de diferentes proporções do genótipo Bos indicus. Botucatu: Universidade Estadual Paulista, 2006. p.99. Tese (Doutorado em Zootecnia) - Universidade Estadual Paulista, 2006.

CUNNINGHAM, J. G. Tratado de fisiologia veterinária. 2.ed. Rio de Janeiro: Guanabara Koogan, 1999, 528p.

DAHLEN, C. R.; DICONSTANZO, A.; MITTENESS, B. M. et al. Influence of a polyclonal antibody preparation against rumen proteolytic bacteria on rumen fermentation and yield of milk and milk components. J. Anim. Sci, v.81 (Suppl.1), p.58, 2003.

DESWYSEN, A.G.; ELLIS, W.C.; POND, K.R. Interrelationships among voluntary intake, eating and ruminating behavior and ruminal motility of heifers fed corn silage. J. Anim. Sci, v.64, p.835-841, 1987.

DILORENZO, N.; DIEZ-GONZALEZ, F.; DICOSTANZO, A. Effects of feeding polyclonal antibody preparations on ruminal bacterial populations and ruminal $\mathrm{pH}$ of steers fed high-grain diets. J. Anim. Sci, v.84, p.2178-2185, 2006.

DILORENZO, N., DAHLEN, C. R.; DIEZ-GONZALEZ, F. et al. Effects of feeding polyclonal antibodies preparations on rumen fermentation patterns, performance, and carcass characteristics of feedlot steers. J. Anim. Sci, v.86, p.3023-3032, 2008.

DINIUS, D. A.; SIMPSON, M. E.; MARSH, P. B. Effect of monensin fed with forage on digestion and the ruminal ecosystem of steers. J. Anim. Sci, v.42, p. 229 234, 1976.

DULPHY, J. P.; et al. Ingestive behavior and related activities in ruminants. In: Digestive physiology and metabolism in ruminants. Wesport., p. 103-122. 1980.

ELAM, N. A., GLEGHORN, J. F.; RIVERA, J. D. et al. Effects of live cultures of Lactobacillus acidophilus (strains NP45 and NP51) and Propionibacterium freudenreichii on performance, carcass, and intestinal characteristics, and Escherichia coli $\mathrm{O} 157$ shedding of finishing beef steers. J. Anim. Sci, v.81, p.2686-2698, 2003. 
EUCLIDES FILHO, K.; EUCLIDES, V.P.B.; FIGUEIREDO, G.R. et al. Avaliação de animais Nelore e seus mestiços Charolês, Fleckvieh e Chianina em três dietas. IGanho de peso e conversão alimentar. Revista Brasileira de Zootecnia, v.26, n.1, p.66-72, 1997.

FERREIRA, M.A. Desempenho, exigências nutricionais e eficiência de utilização de energia metabolizável para ganho de peso de bovinos F1 Simental $x$ Nelore. Viçosa, MG: UFV, 1997. 97p. Tese (Doutorado em Zootecnia) - Universidade Federal de Viçosa, 1997.

FERRELL, C. L.; BERRY, E. D.; FREETLY, H. C. et al. Influence of genotype and diet on steer performance, manure odor, and carriage of pathogenic and other fecal bacteria. I. Animal performance. J. Anim. Sci, v.84, p.2515 - 2522, 2006.

FOX, D. G.; SNIFFEN, C. J.; O'CONNOR, J. D. Adjusting nutrient requirements of beef cattle for animal and environmental variations. J. Anim. Sci, v.66, p.1475$1495,1988$.

FRISCH, J. E.; VERCOE, J. E. Food intake, eating rate, weight gains, metabolic rate and efficiency of feed utilization in Bos Taurus and Bos indicus crossbred cattle. Animal Production, v.24, p.343-358, 1977.

GALYEAN, M. L.; MALCOLM, K. F.; DUFF, G. C. Performance of feedlot steers fed diets containing laidlomycin propionate or monensin plus tylosin, and effects of laidlomycin propionate concentration on intake patterns and ruminal fermentation in beef steers during adaptation to a high concentrate diet. J. Anim. Sci, v.70(10), p.2950-2958, 1992 .

GESUALDI JÚNIOR, A.; PAULINO, M.F.; VALADARES FILHO, S.C. et al. Níveis de concentrado na dieta de novilhos F1 Limousin x Nelore: Consumo, conversão alimentar e ganho de peso. Revista Brasileira de Zootecnia, v.29, n.5, p.1458 1466, 2000.

GHORBANI, G. R.; MORGAVI, D. P.; BEAUCHEMIN, K. A. et al. Effects of bacterial direct-fed microbials on ruminal fermentation, blood variables, and the microbial populations of feedlot cattle. J. Anim. Sci, v.80, p.1977-1986, 2002.

GILL, H. S.; SHU, Q.; LENG, R. A. et al. Immunization with Streptococcus bovis protects against lactic acidosis in sheep. Vaccine, v.18, p.2541-2548, 2000. 
GOERING, H. K.; VAN SOEST, P. J. Forage fiber analysis. Agriculture Handbook, Agricultural Research Service. Washington D.C., 1970, 19 p.

GONÇALVES, L.C., SILVA, J.F.C., ESTEVÃO, M.M. et al. Consumo e digestibilidade da matéria seca e da energia em zebuínos e taurinos, seus mestiços e bubalinos. Revista Brasileira de Zootecnia, v.20, n.4, p.384-395, 1991.

HANSON, T. L.; KLOPFENSTEIN, T. Monensin, protein source and protein levels for growing steers. J. Anim. Sci, v.48, p.474 - 479, 1979.

JOHNSON, T. R.; COMBS, D. K. Effects of prepartum diet, inert rumen bulk, and dietary polythylene glicol on dry matter intake of lactating dairy cows. J. Dairy Sci, v.74(3), p.933-944, 1991.

KREHBIEL, C. R.; KREIKEMEIER, K. K.; FERRELL, C. L. Influence of Bos indicus crossbreeding and cattle age on apparent utilization of a high grain diet. J. Anim. Sci, v.78, p.1641-1647, 2000.

LEDGER, H. P.; ROGERSON, A.; FREEMAN, G. R. Further studies on the voluntary food intake of Bos indicus, Bos taurus and crossbred cattle. Animal Production, v.12, p.425-432, 1970.

LEME, P. R. et al. Desempenho em confinamento e características de carcaça de bovinos machos de diferentes cruzamentos abatidos em três faixas de peso. Revista Brasileira de Zootecnia, Viçosa, v.29, n.6, supl.2, p.2347 - 2353, 2000.

MERTENS, D.R. 1997. Creating a system for meeting the fiber requirements of dairy cows. J. Dairy Sci., 80(5):1463-1481.

MERTENS, D.R. Analysis of fiber in feeds and its uses in feed evaluation and ration formulation. In: TEIXEIRA, J.C.; NEIVA, R.S. (Eds.). Anais do Simpósio Internacional de Ruminantes. SBZ, Lavras, MG, Brasil, 1992. p.01-32.

MERTENS, D.R. Using fiber and carbohydrate analyses to formulate dairy rations.

Wisconsin: Us Dairy Forage Research Center, 1996. p.81-92. (Informational Conference with Dairy and Forages Industries), 1996.

MILlEN, D. D.; PACHECO, R. D. L.; ARRIGONI, M. D. B. et al. Feedlot performance and rumen parakeratosis incidence in Bos indicus type bullocks fed high grain diets and monensin or polyclonal antibodies preparations against rumen bacteria. J. Anim. Sci, v.85, (supplement1), p.552, 2007. 
MILLEN, D. D. Desempenho, avaliação ruminal e perfil metabólico sanguíneo de bovinos jovens confinados suplementados com monensina sódica ou anticorpos policlonais. Botucatu: Universidade Estadual Paulista, 2008. Tese (Mestrado em Zootecnia) - Universidade Estadual Paulista, 2008.

MILlEN, D. D.; PACHECO; R. D. L.; ARRIGONI, M. D. B. et al. Feedlot performance of Nellore and Brangus cattle fed monensin or polyclonal antibody preparation against lactate-producing rumen bacteria. J. Anim. Sci, v.87, ESuppl.2, p.282, 2009.

NEWBOLD, C. J.; STEWART, C. S.; WALLACE, R. J. 2001. Developments in rumen fermentation - The scientist's view. Pages 251-279 in Recent Advances in Animal Nutrition 2001. P. C. Garnsworthy and J. Wiseman ed. Nottingham University Press, Nottingham, United Kingdom.

OJEU, 2003. Official Journal of the European Union. Regulation (EC) No 1831/2003 of the European Parliament and the Council of 22 of September of 2003 on Additives for Use in Animal Nutrition. Pages L268/29-L268/43 in OJEU of $10 / 18 / 2003$.

OWENS, F.N.; DUBESKI, P.; HANSON, C.F. Factors that alter the growth and development in ruminants. J. Anim. Sci., v.71, p.31 - 38, 1993.

OWENS, F. N.; SECRIST, D. S.; HILL, W. J. et al. Acidosis in cattle: A review. J. Anim. Sci, v.76, p.275-286, 1998.

PERKINS, T. L.; GREEN, R. D.; HAMLIN, K. E. Evaluation of ultrasonic estimates of carcass fat thickness and longissimus muscle area in beef cattle. J. Anim. Sci, v.70, p.1002-1010, 1992.

PRANGE, R. W.; DAVIS, C. L.; CLARKE, J. H. Propionate production in the rumen of Holstein steers fed either a control or monensin supplemented diet. J. Anim. Sci, v.46, p.1120 - 1124, 1978.

RAUN, A. P.; COOLEY, C. O.; POTTER, E. L. et al. Effect of monensin on feed efficiency of feedlot cattle. J. Anim. Sci, v.43, p.670 - 677, 1976.

RICHARDSON, L. F.; RAUN, A. P.; POTTER, E. L. et al. Effect of monensin on ruminal fermentation in vitro and in vivo. J. Anim. Sci, v.43, p.657 - 664, 1976. 
ROBLES, V,; GONZÁleZ, A. F.; CALSAMIGLIA, S. et al. Effects of feeding frequency on intake, ruminal fermentation and feeding behavior in heifers fed high-concentrate diets. J. Anim. Sci, v.85, p.2538-2547, 2007.

ROGERS, J. A.; DAVIS, C. L. Rumen volatile fatty acids production and nutrient utilization in steers fed a diet supplemented with sodium bicarbonate and monensin. J. Dairy Sci, v.65, p.944 - 952, 1982.

ROGERSON, A.; LEDGER, H. P.; FREEMAN, G. H. Food intake and liveweight gain comparison of Bos indicus and Bos Taurus steers on a high plane of nutrition. Animal Production, v.10, p.373, 1968.

ROTGER, A.; FERRET, A.; MANTECA, X. Effects of dietary nonstructural carbohydrates and protein sources on feeding fed high-concentrate diets. J. Anim. Sci, v.84, p.1197-1204, 2006.

RUST, S. R.; METZ, K.; WARE, D. R. Effects of Bovamine rumen culture on the performance and carcass characteristics of feedlot steers. J. Anim. Sci, v.78 (Suppl. 2), p.82 (Abstr.), 2000.

SARTI, L. M. N.; PACHECO, R. D. L.; MILLEN, D. D. et al. Evaluation of feeding behavior of young cattle from different genetic groups fed with high concentrate diets with different NDF levels. J. Anim. Sci, v.85, Suppl.1, p.552-553, 2007.

SAS. SAS User's Guide: Statistics (Version 5 Ed.). SAS Inst. Inc., Cary, NC, 2003.

SHERBECK, J. A.; TATUM, J. D.; FIELD, T. G. et al. Effect of phenotypic expression of Brahman breeding on marbling and tenderness traits. J. Anim. Sci, v.74, p.304 $-309,1996$.

SHU, Q.; GILL, H. S.; HENNESSY, D. W. et al. Immunization against lactic acidosis in cattle. Research of Veterinary Science, v.67, p.65-71, 1999.

SHU, Q.; GILL, H. S.; LENG, J. B. et al. Immunization with a Streptococcus bovis vaccine administered by different routes against lactic acidosis in sheep. Vet. J., v.159, p.262-269, 2000. 
STOCK, R. A.; LAUDERT, S. B.; STROUP, W. W. Effects of monensin and monensin and tylosin combination on feed intake variation of feedlot steers. J. Anim. Sci, v.73, p.39-44, 1995.

THORNTON, J.H. \& OWENS, F.N. Monensin supplementation and in vivo methane production by steers. J. Anim. Sci., 52: 628 - 634, 1981.

TURNER, J. W. Genetic and biological aspects of zebu adaptability. J. Anim. Sci, v.50, n.6, 1980 .

VALADARES FILHO, S.C.; AZEVEDO, J.A.G.; PINA, D.S. et al. Consumo de matéria seca de bovinos Nelore e mestiços. In: Exigências Nutricionais Zebuínos e Tabelas de Composição de Alimentos - BR Corte. VALADARES FILHO, S.C.; PAULINO, P.V.R.; MAGALHÃES, K.A. (Eds.). Universidade Federal de Viçosa. p.1 - 11, 2006.

VAN SOEST, P. J. Nutitional ecology of the ruminant. 2.ed. Ithaca: Cornell University Press. P.476, 1994. 
Tabela 1. Ingredientes e composição química das dietas experimentais fornecidas durante o estudo.

\begin{tabular}{lcccc}
\hline \hline & \multicolumn{4}{c}{ Nível de Concentrado } \\
\cline { 2 - 5 } Ítem & $55 \%$ & $70 \%$ & $80 \%$ & $85 \%$ \\
\hline Períodos & ADAP & CRES & TRM1 & TRM2 \\
Dias de Alimentação & 28 & 56 & 30 & 30 \\
Ingredientes, \% da MS & & & & \\
Feno de Coast Cross & 16,4 & 3,30 & 4,40 & 5,70 \\
Bagaço de Cana Cru & 28,4 & 26,7 & 15,8 & 9,40 \\
Silagem de Grãos Úmidos de Milho & 16,4 & 19,6 & 28,2 & 31,9 \\
Grãos de Milho Seco Quebrados & 10,4 & 15,6 & 9,70 & 8,40 \\
Polpa Cítrica & 9,00 & 15,0 & 25,5 & 32,4 \\
Farelo de Soja & 17,9 & 18,3 & 14,8 & 10,5 \\
Suplemento Mineral com 30\% de Uréia ${ }^{2}$ & 1,50 & 1,50 & 1,60 & 1,70 \\
Composição Bromatológica & & & & \\
MS (\% da Matéria Natural) & 74,0 & 73,0 & 65,0 & 71,0 \\
NDT & 69,0 & 72,0 & 75,0 & 78,0 \\
Elg, ${ }^{3,5}$ Mcal/kg de MS & 0,99 & 1,08 & 1,17 & 1,24 \\
CNF & 42,5 & 47,0 & 54,7 & 58,6 \\
Proteína Bruta & 16,8 & 15,6 & 14,4 & 13,2 \\
Extrato Etéreo & 3,30 & 3,60 & 3,50 & 3,80 \\
FDN & 36,4 & 30,2 & 23,1 & 20,4 \\
Ca & 0,46 & 0,54 & 0,75 & 0,89 \\
P & 0,34 & 0,35 & 0,34 & 0,32 \\
\hline ISuplemyyyyyy
\end{tabular}

${ }^{\mathrm{T}}$ Suplemento continha $30 \%$ de uréia, assim como Ca, 26,7\%; P, 5,3\%; Na, 10,9\%; S, 1,5\%; Zn, 2600 ppm; Mn, 1300 ppm; Cu, 1032 ppm; I, 45,0 ppm; Se, 15,0 ppm; Co, 154 ppm; e Fe, 2500 ppm.

${ }^{2}$ Nutrientes Digestíveis Totais.

${ }^{3}$ Energia Liquida para ganho.

${ }^{4}$ Carboidratos Não Fibrosos.

${ }^{5}$ Estimado segundo equações do CNCPS (2000). 


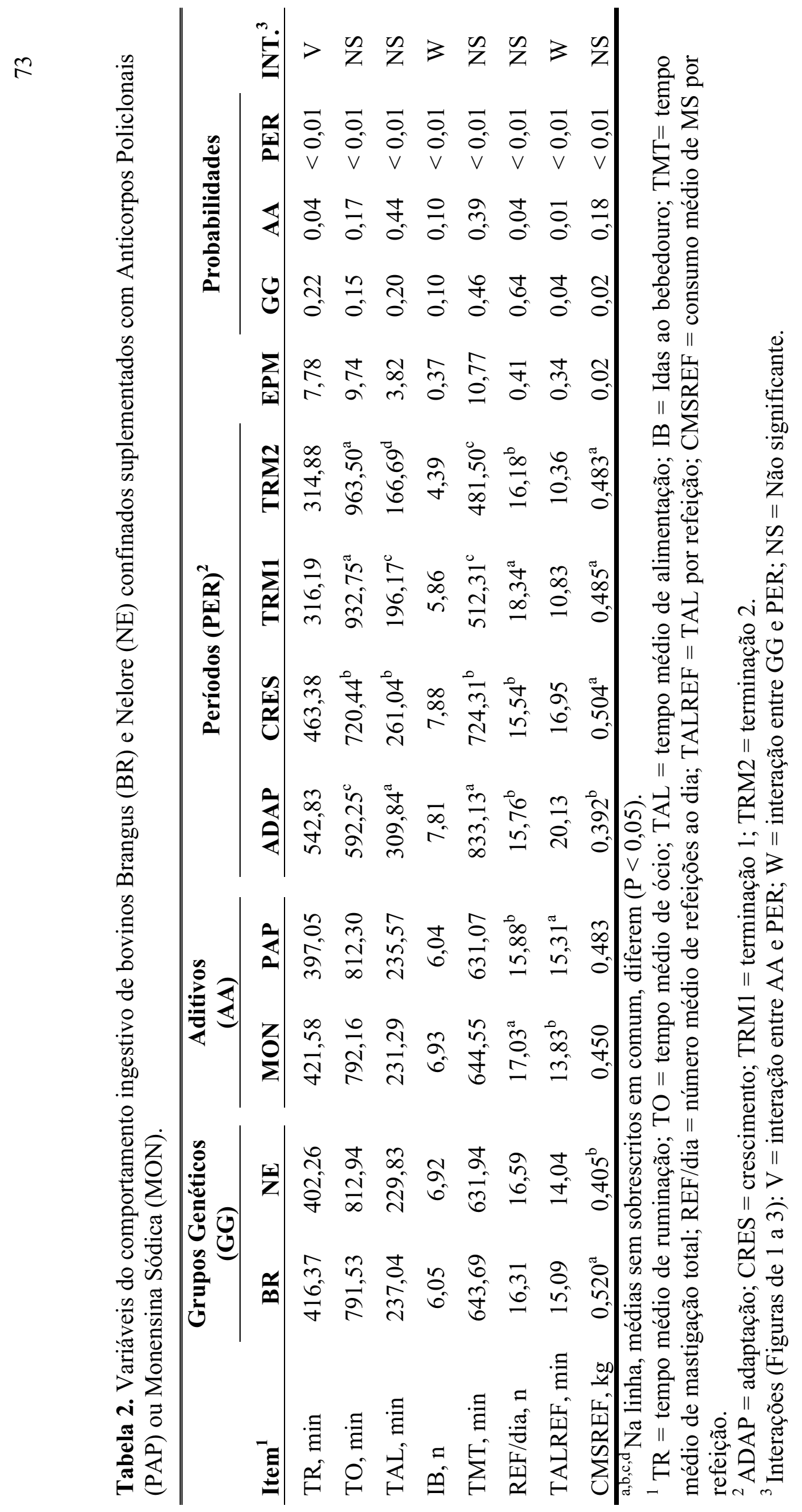




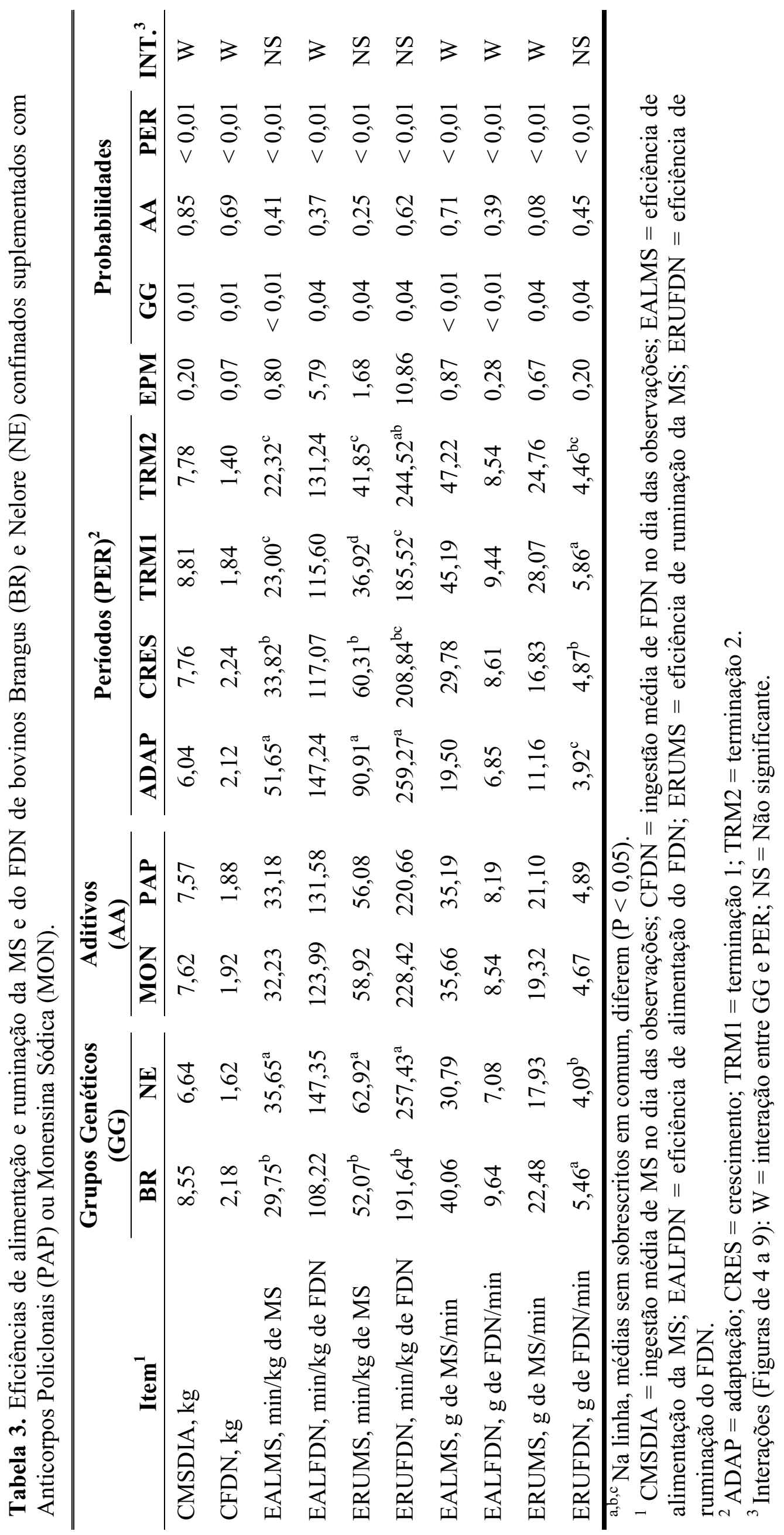




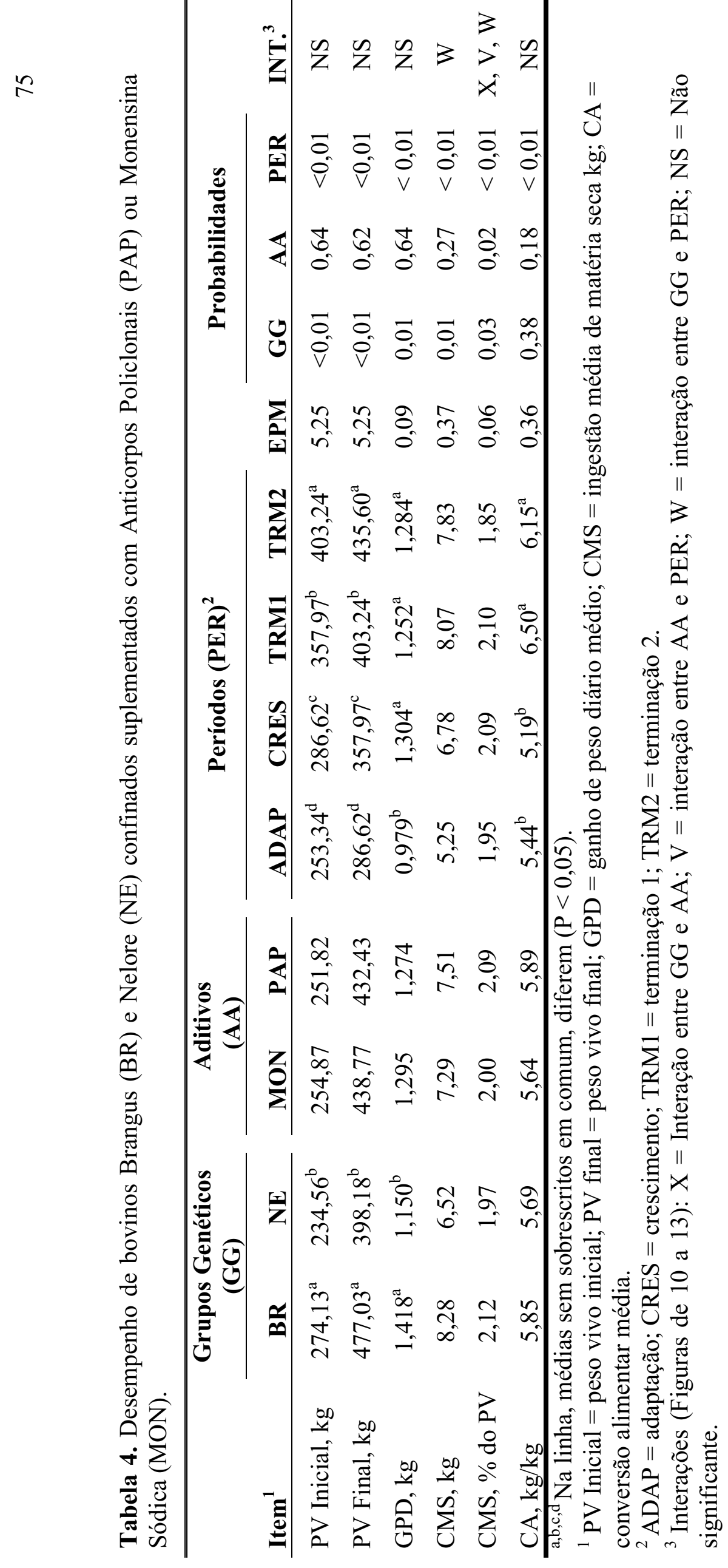




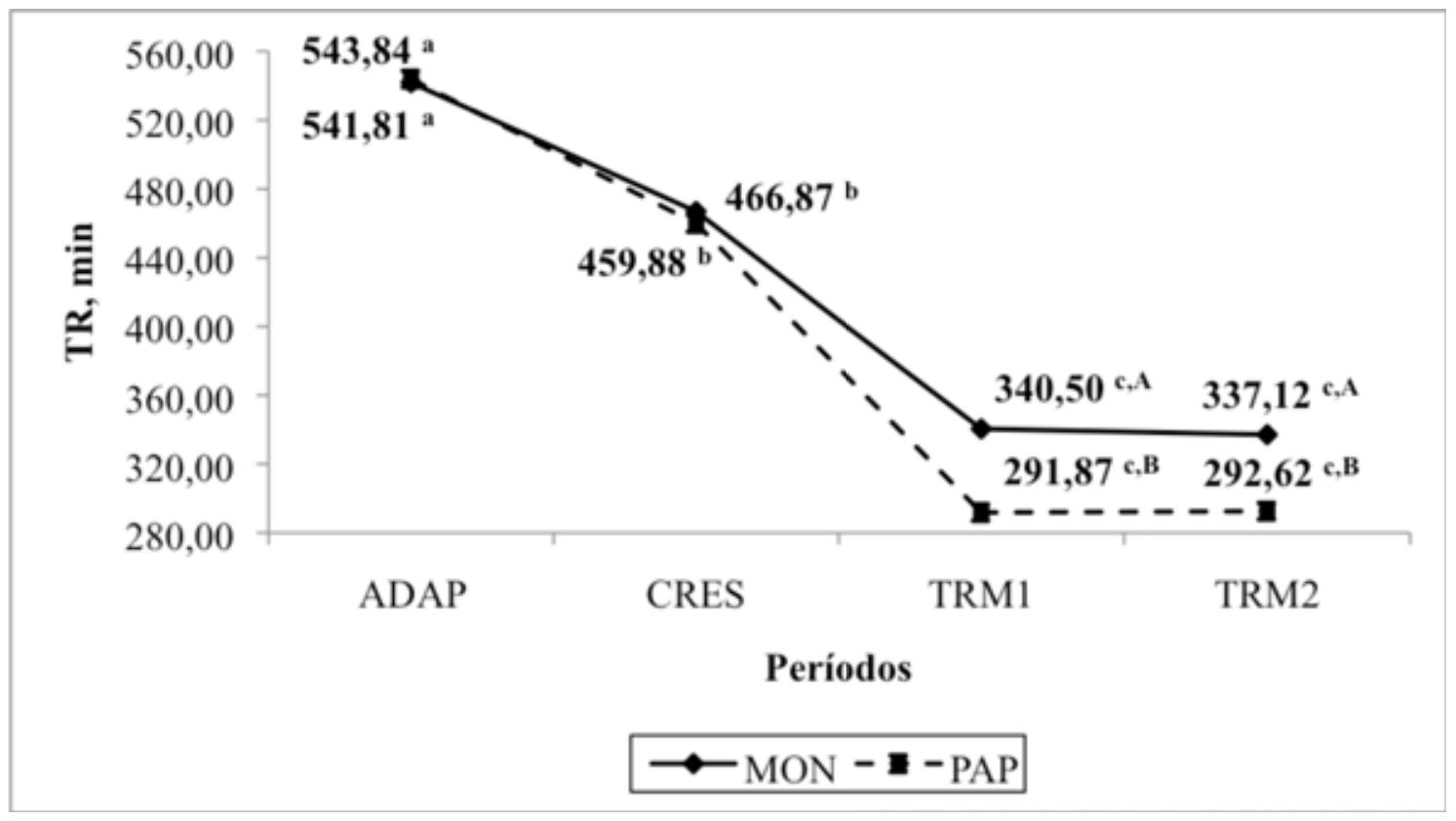

Figura 1. Interação entre aditivo alimentar e período para o tempo médio despendido em ruminação (TR). ${ }^{a, b, c} \mathrm{Na}$ linha, médias sem sobrescritos em comum, diferem $(\mathrm{P}<$ $0,05) .{ }^{\mathrm{A}, \mathrm{B}} \mathrm{Na}$ coluna, médias sem sobrescritos em comum, diferem $(\mathrm{P}<0,05)$. 


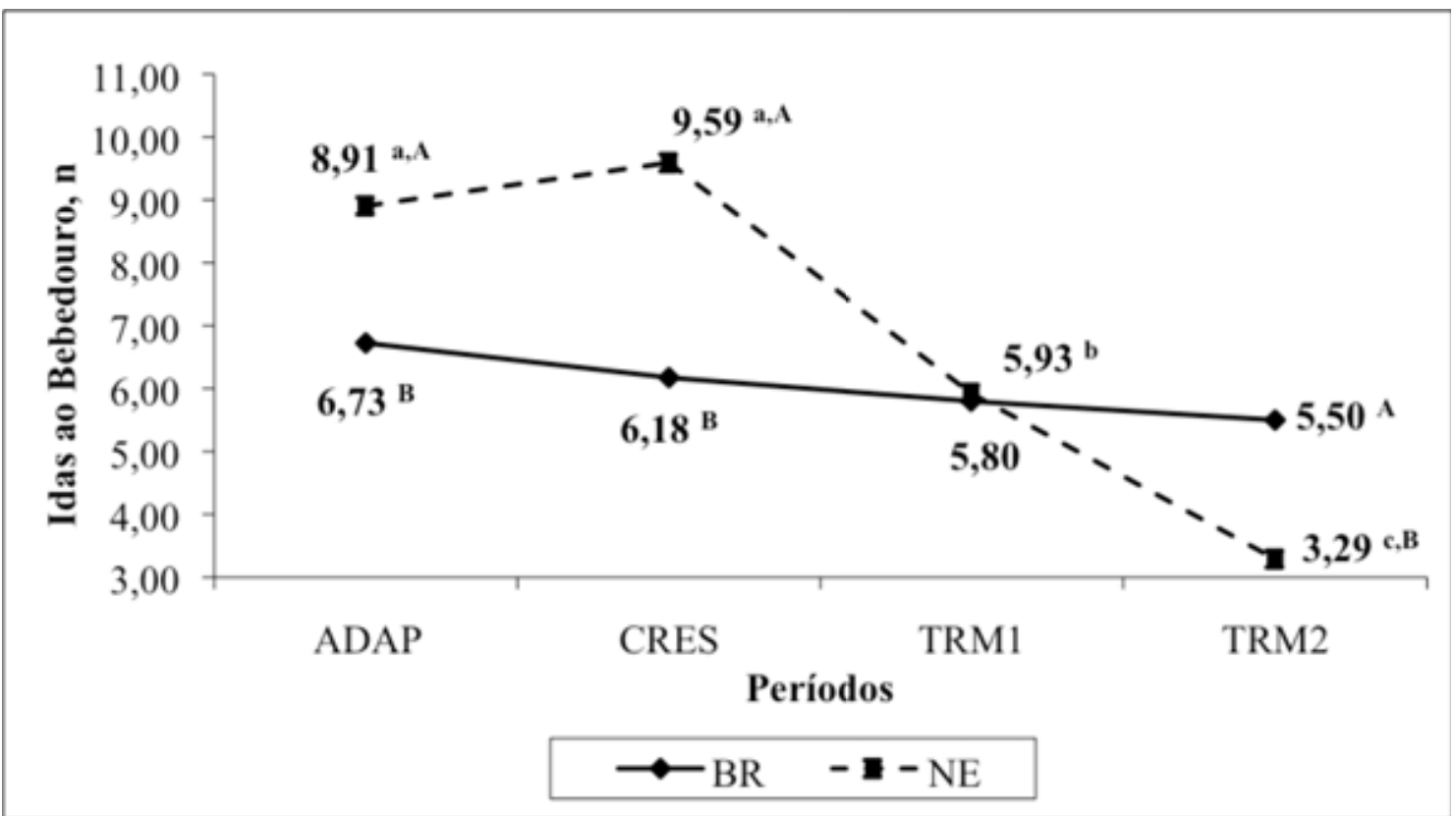

Figura 2. Interação entre grupo genético e período para idas ao bebedouro. ${ }^{\mathrm{a}, \mathrm{b}, \mathrm{c}} \mathrm{Na}$ linha, médias sem sobrescritos em comum, diferem $(\mathrm{P}<0,05)$. ${ }^{\mathrm{A}, \mathrm{B}} \mathrm{Na}$ coluna, médias sem sobrescritos em comum, diferem $(\mathrm{P}<0,05)$. 


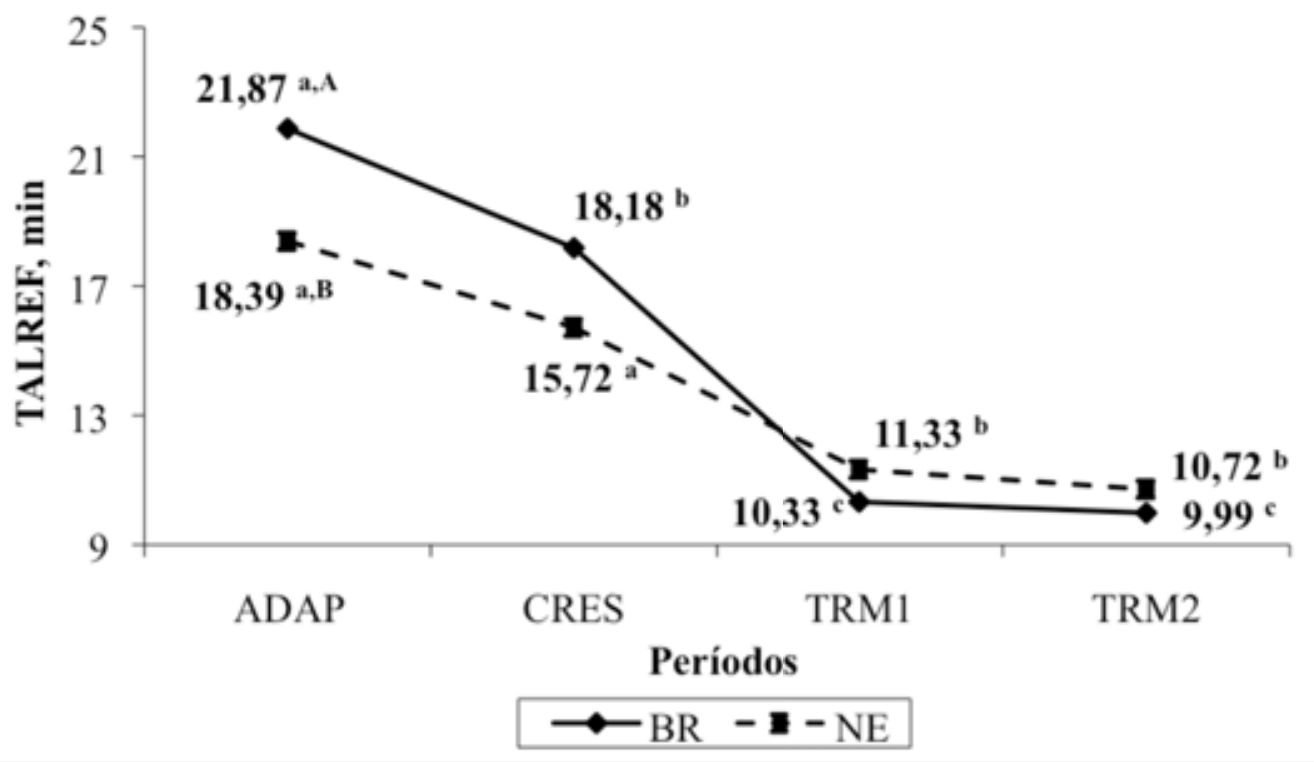

Figura 3. Interação entre grupo genético e período para tempo médio de alimentação por refeição (TALREF). ${ }^{\mathrm{a}, \mathrm{b}, \mathrm{c}} \mathrm{Na}$ linha, médias sem sobrescritos em comum, diferem $(\mathrm{P}<$ $0,05) .{ }^{\mathrm{A}, \mathrm{B}} \mathrm{Na}$ coluna, médias sem sobrescritos em comum, diferem $(\mathrm{P}<0,05)$. 


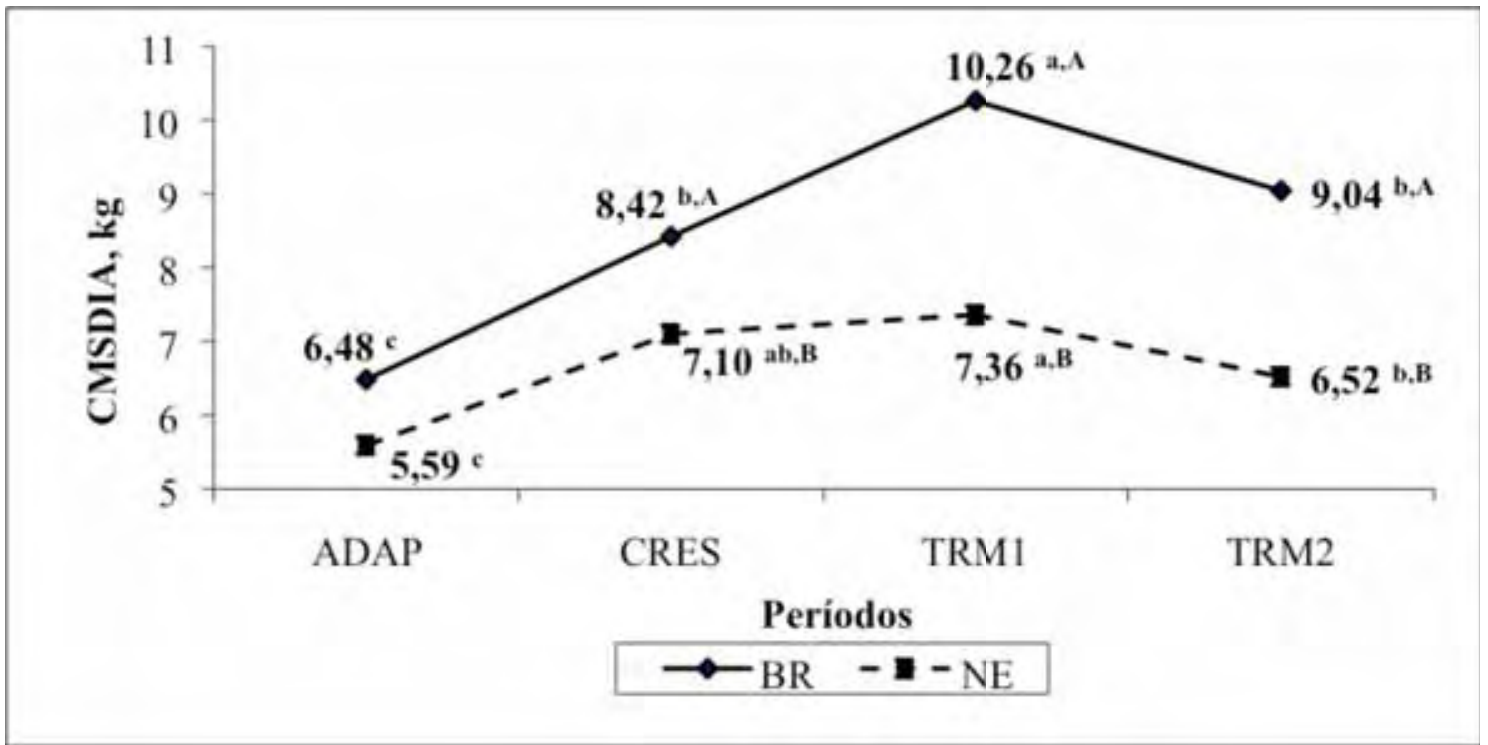

Figura 4. Interação entre grupo genético e período para consumo médio de matéria seca no dia das observações (CMSDIA). ${ }^{\mathrm{a}, \mathrm{b}, \mathrm{c}} \mathrm{Na}$ linha, médias sem sobrescritos em comum, diferem $(\mathrm{P}<0,05) .{ }^{\mathrm{A}, \mathrm{B}} \mathrm{Na}$ coluna, médias sem sobrescritos em comum, diferem $(\mathrm{P}<$ $0,05)$. 


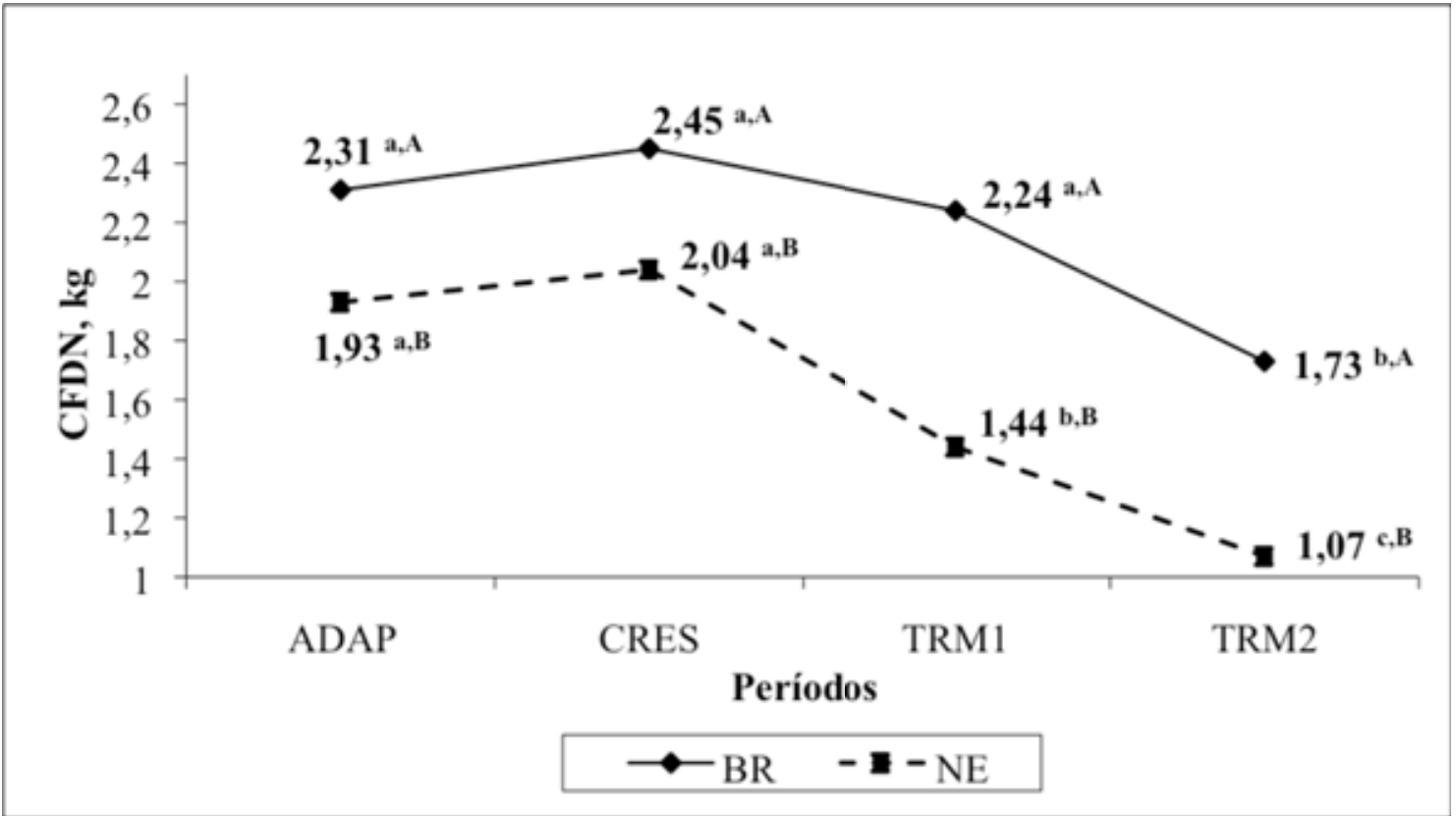

Figura 5. Interação entre grupo genético e período para consumo médio de FDN no dia das observações (CFDN). ${ }^{\text {a,b,c }} \mathrm{Na}$ linha, médias sem sobrescritos em comum, diferem (P $<0,05) .{ }^{\mathrm{A}, \mathrm{B}} \mathrm{Na}$ coluna, médias sem sobrescritos em comum, diferem $(\mathrm{P}<0,05)$. 


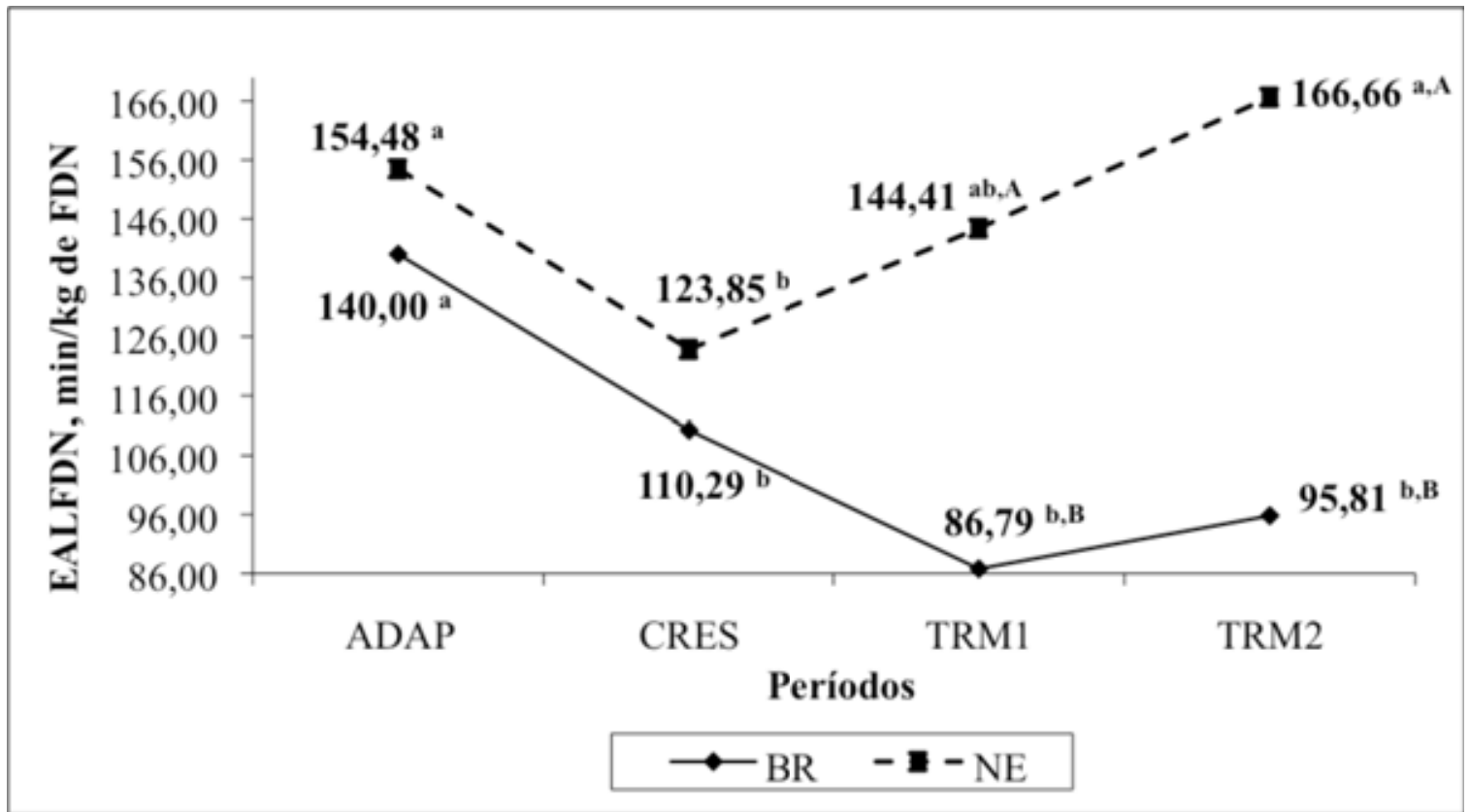

Figura 6. Interação entre grupo genético e período para eficiência de alimentação do FDN (EALFDN). ${ }^{a, b} \mathrm{Na}$ linha, médias sem sobrescritos em comum, diferem $(\mathrm{P}<0,05)$. ${ }^{\mathrm{A}, \mathrm{B}} \mathrm{Na}$ coluna, médias sem sobrescritos em comum, diferem $(\mathrm{P}<0,05)$. 


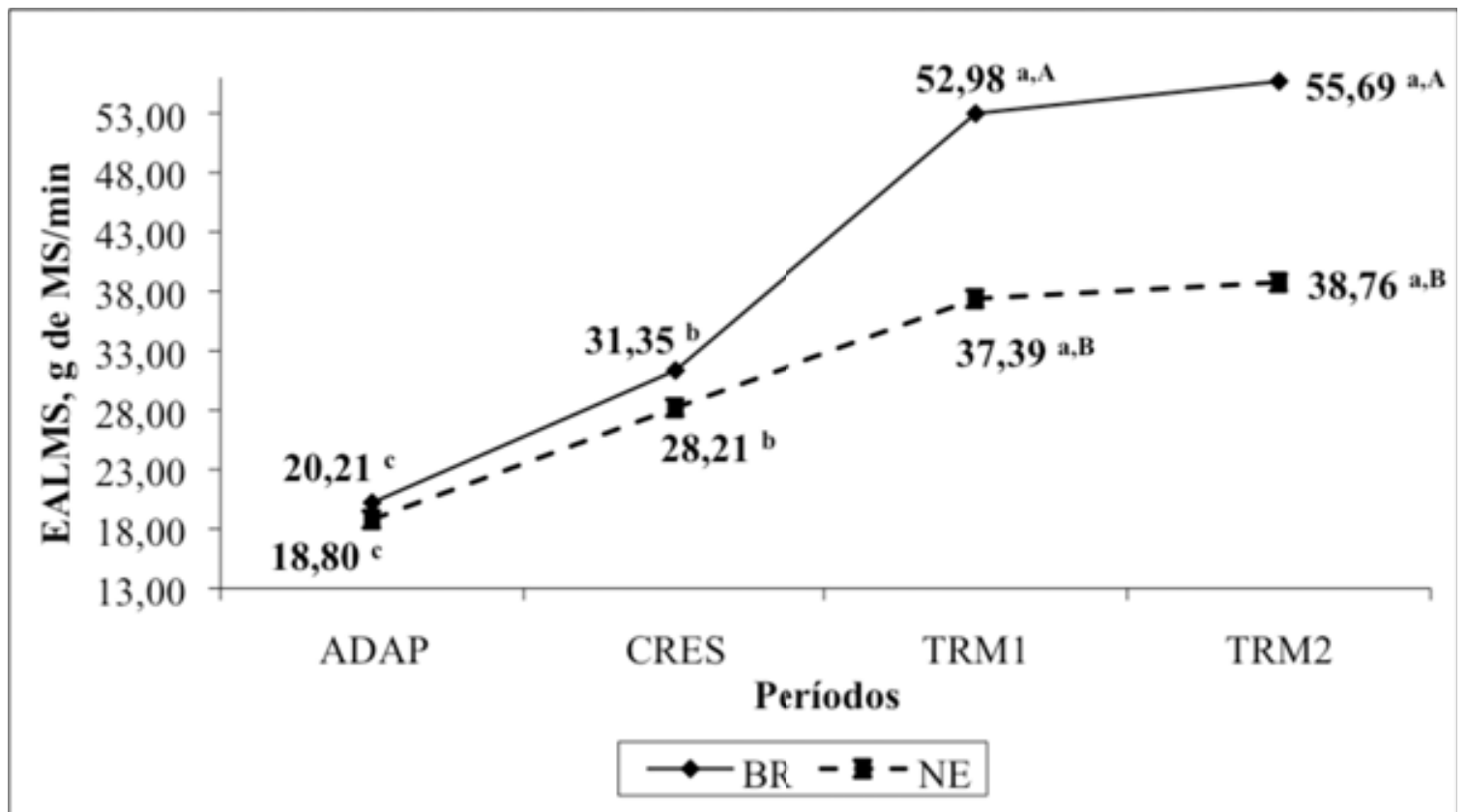

Figura 7. Interação entre grupo genético e período para eficiência de alimentação da MS (EALMS). ${ }^{a, b, c} \mathrm{Na}$ linha, médias sem sobrescritos em comum, diferem $(\mathrm{P}<0,05)$. ${ }^{\mathrm{A}, \mathrm{B}} \mathrm{Na}$ coluna, médias sem sobrescritos em comum, diferem $(\mathrm{P}<0,05)$. 


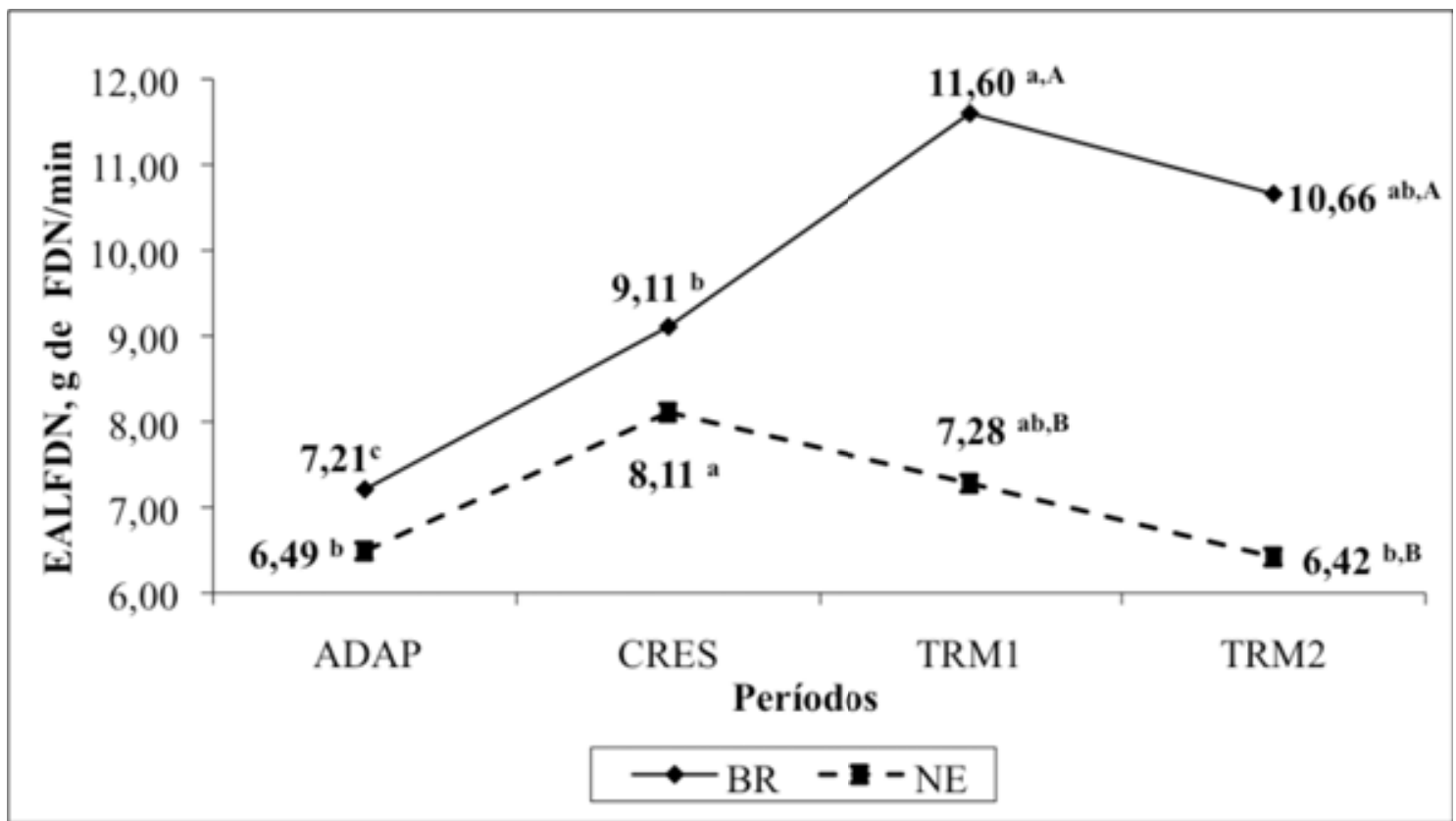

Figura 8. Interação entre grupo genético e período para eficiência de alimentação do FDN (EALFDN). ${ }^{a, b, c} \mathrm{Na}$ linha, médias sem sobrescritos em comum, diferem $(\mathrm{P}<0,05)$. ${ }^{\mathrm{A}, \mathrm{B}} \mathrm{Na}$ coluna, médias sem sobrescritos em comum, diferem $(\mathrm{P}<0,05)$. 


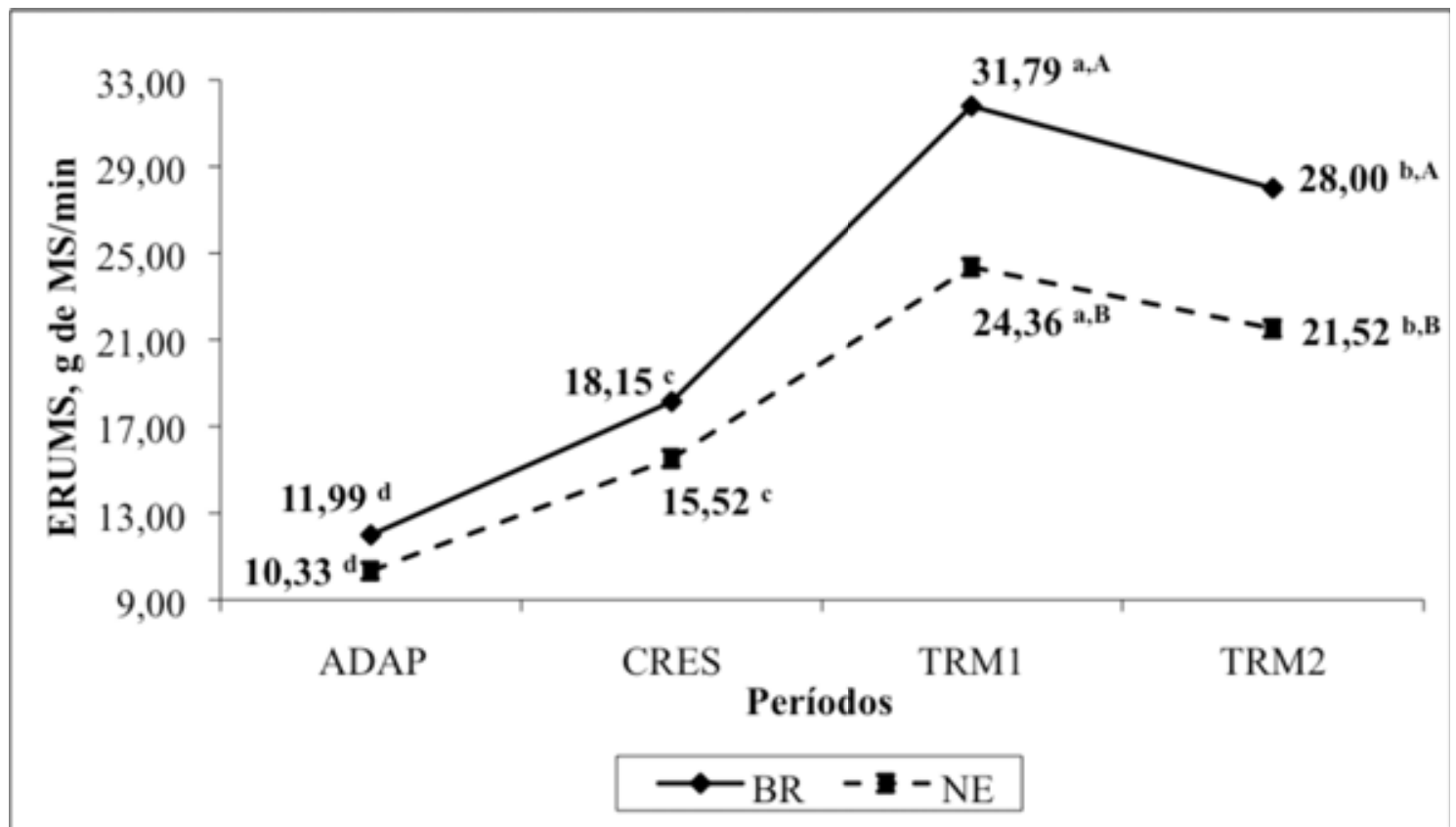

Figura 9. Interação entre grupo genético e período para eficiência de ruminação da $\mathrm{MS}$ (ERUMS). ${ }^{\text {a,b,c,d }} \mathrm{Na}$ linha, médias sem sobrescritos em comum, diferem $(\mathrm{P}<0,05) .{ }^{\mathrm{A}, \mathrm{B}}$ Na coluna, médias sem sobrescritos em comum, diferem $(\mathrm{P}<0,05)$. 


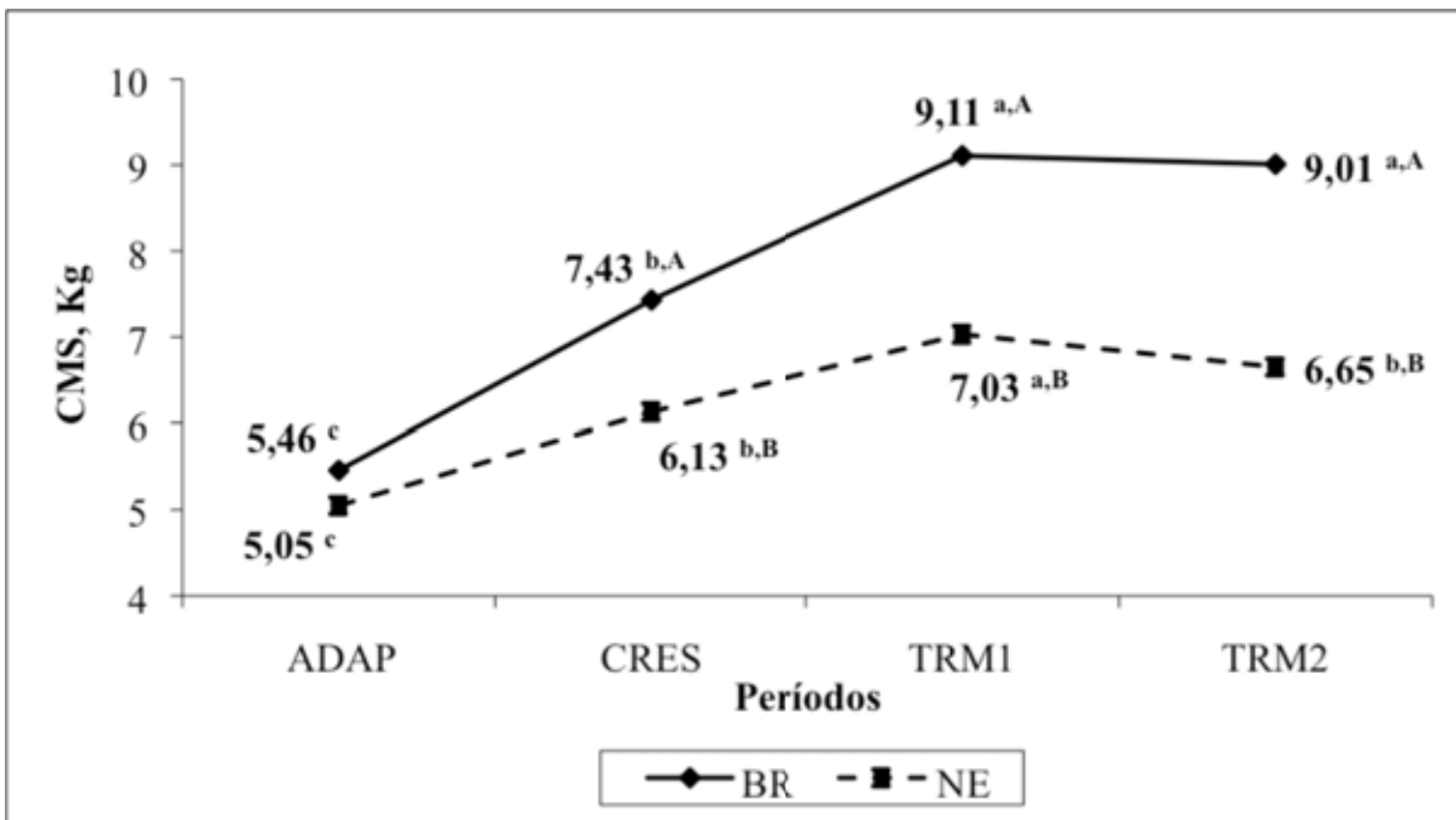

Figura 10. Interação entre grupo genético e período para consumo de MS (CMS) em quilos. ${ }^{\mathrm{a}, \mathrm{b}, \mathrm{c}} \mathrm{Na}$ linha, médias sem sobrescritos em comum, diferem $(\mathrm{P}<0,05) .{ }^{\mathrm{A}, \mathrm{B}} \mathrm{Na}$ coluna, médias sem sobrescritos em comum, diferem $(\mathrm{P}<0,05)$. 


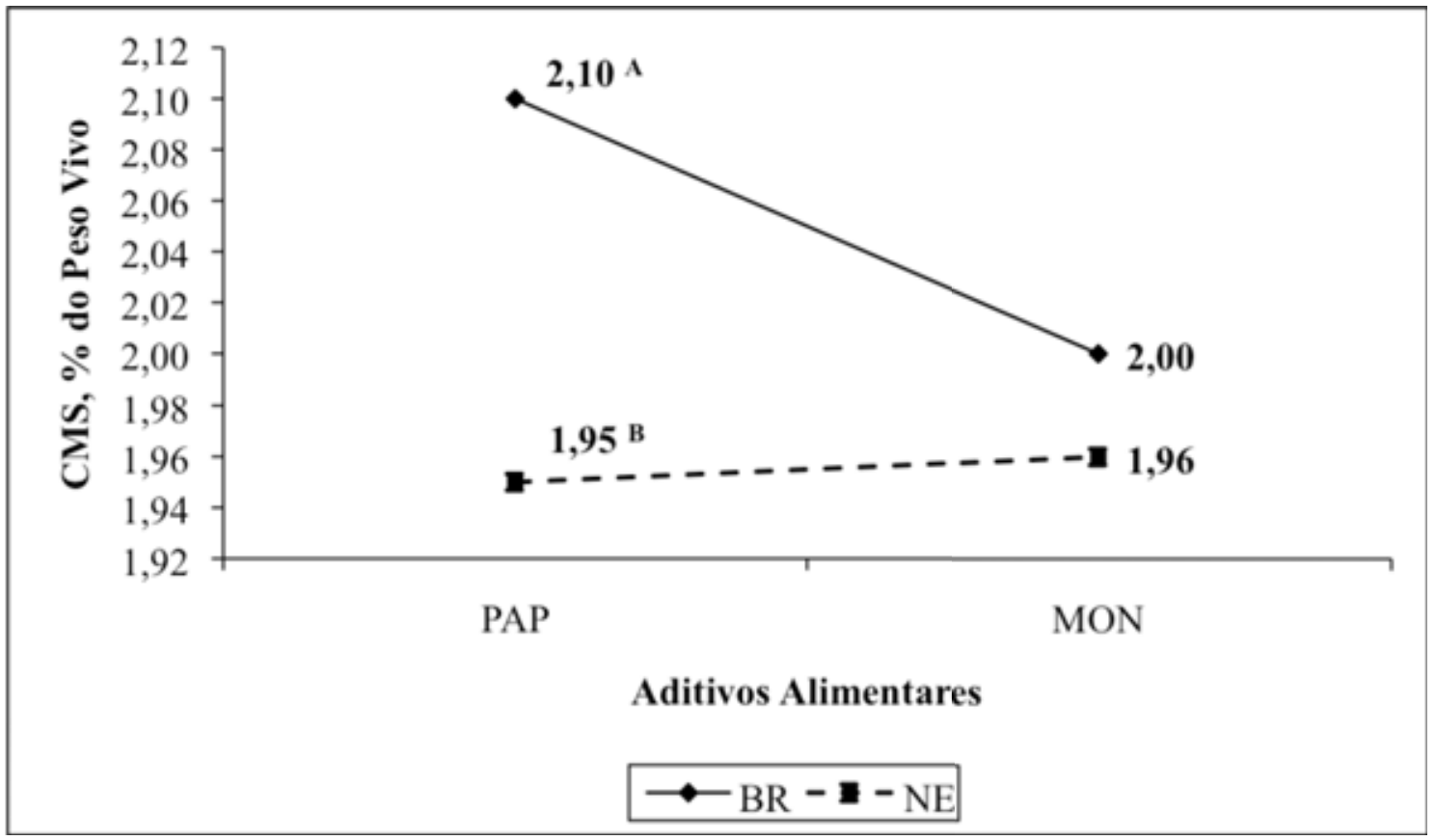

Figura 11. Interação entre grupo genético e aditivo alimentar para o consumo de MS (CMS) em porcentagem do peso vivo. ${ }^{\mathrm{A}, \mathrm{B}}$ Médias sem sobrescritos em comum na coluna, diferem $(\mathrm{P}<0,05)$. 


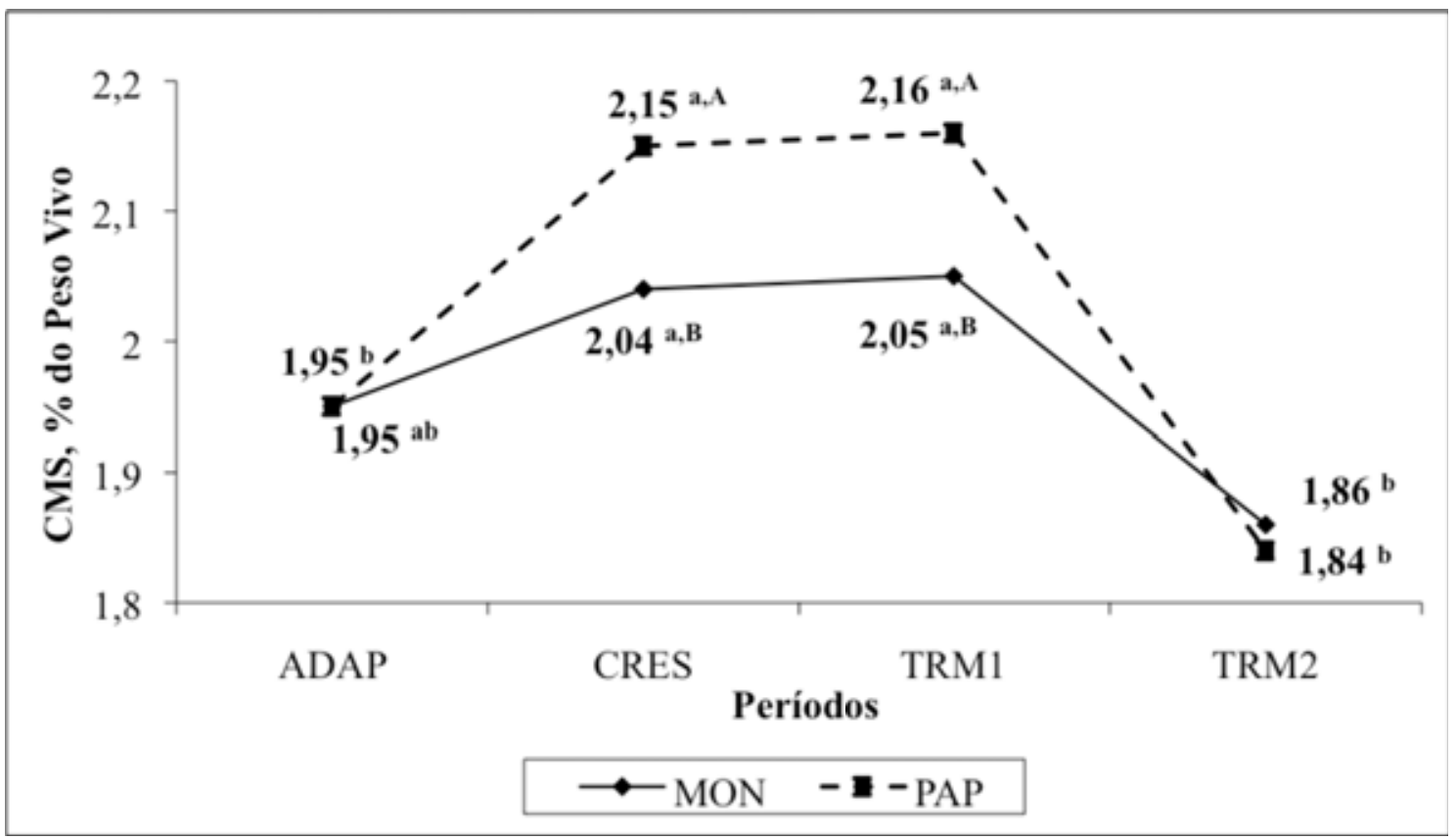

Figura 12. Interação entre aditivo alimentar e período para consumo de MS (CMS) em porcentagem do peso vivo. ${ }^{\mathrm{a}, \mathrm{b}} \mathrm{Na}$ linha, médias sem sobrescritos em comum, diferem (P $<0,05)$. ${ }^{\mathrm{A}, \mathrm{B}} \mathrm{Na}$ coluna, médias sem sobrescritos em comum, diferem $(\mathrm{P}<0,05)$. 


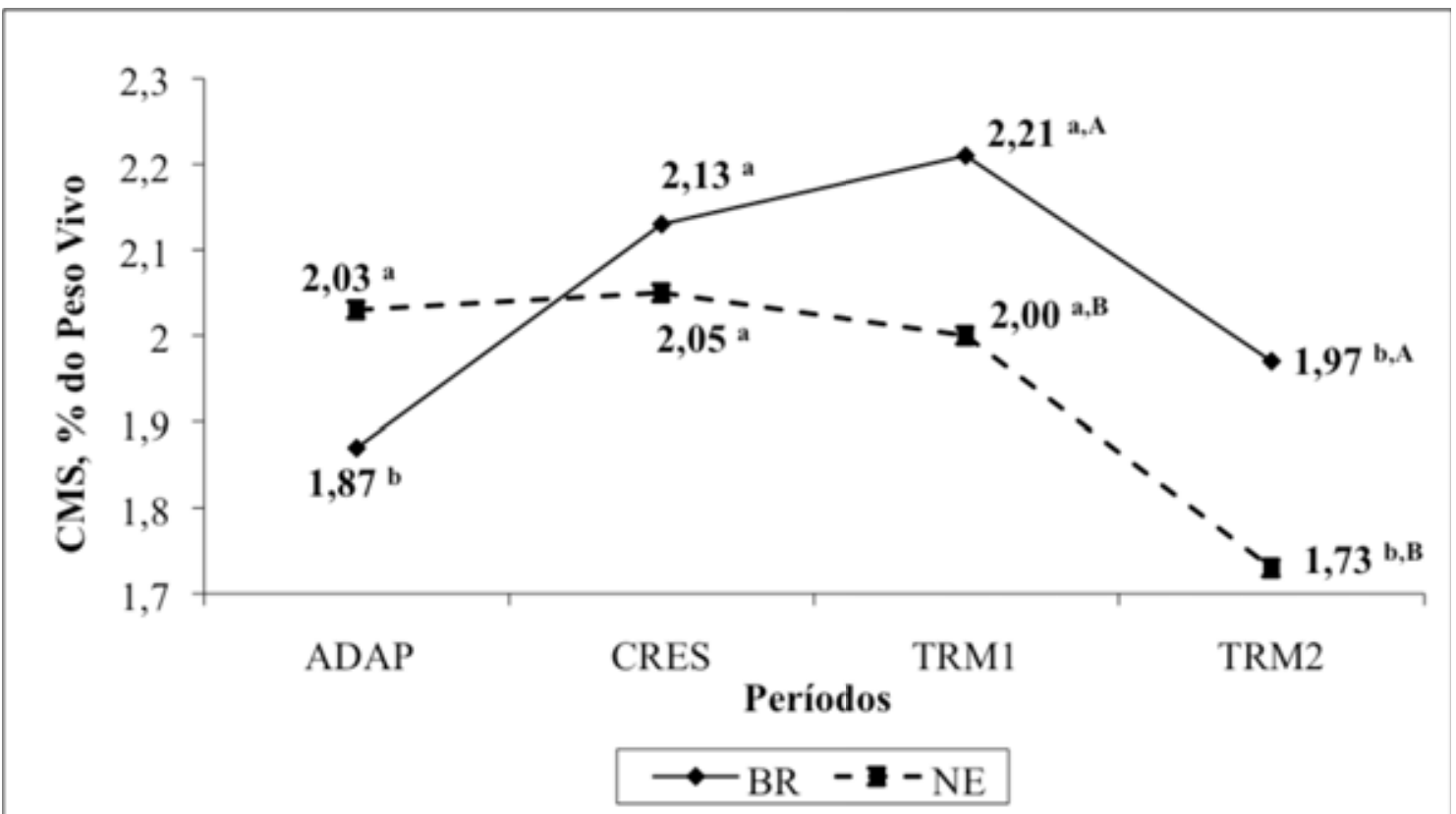

Figura 13. Interação entre grupo genético e período para consumo de MS (CMS) em porcentagem do peso vivo. ${ }^{\mathrm{a}, \mathrm{b}} \mathrm{Na}$ linha, médias sem sobrescritos em comum, diferem (P $<0,05) .{ }^{\mathrm{A}, \mathrm{B}} \mathrm{Na}$ coluna, médias sem sobrescritos em comum, diferem $(\mathrm{P}<0,05)$. 


\section{CAPÍTULO 3}




\section{IMPLICAÇÕES}

Mais estudos são necessários para se esclarecer mais profundamente as razões pelas quais bovinos Zebu são menos eficientes e consequentemente apresentam pior desempenho quando são alimentados com dietas de alto teor de concentrado, que bovinos Taurinos ou cruzados.

Aliado a isso, a técnica de imunização para controlar populações específicas de microorganismos ruminais surge como nova tecnologia que tem grande potencial para produção animal, especialmente quando consideramos futuras linhas na produção animal e a proibição de antibióticos, a qual pode ser aplicada como resultado de preocupação pública em relação ao uso excessivo de antibióticos na produção animal. O uso de imunização passiva via oral parece ser uma ferramenta nutricional que, num futuro próximo, poderia ser largamente utilizada. No entanto, necessita-se de mais pesquisas em relação ao PAP, principalmente para se determinar os mecanismos pelos quais seus efeitos são atingidos e a dosagem ótima de inclusão do produto das dietas de bovinos confinados. Em estudos futuros envolvendo delineamentos experimentais similares a este, a inclusão de controle negativo como um dos tratamentos seria extremamente útil.

O uso do comportamento ingestivo mostrou-se como uma ferramenta importante e de grande utilidade para desenvolver e auxiliar estudos que sirvam de suporte a pesquisa e possibilitem ajustar técnicas de manejo e alimentação para melhorar o desempenho zootécnico dos animais. 